Paula Fernanda Teixeira

\title{
Investigação sobre as Características Geotécnicas de um Resíduo de Papel
}

\author{
Dissertação apresentada à \\ Escola Politécnica da \\ Universidade de São Paulo para \\ obtenção do título Grau de \\ Mestre em Engenharia.
}

São Paulo

2002 


\title{
Paula Fernanda Teixeira
}

\author{
Dissertação apresentada à

Escola Politécnica da \\ Universidade de São Paulo para \\ obtenção do título Grau de \\ Mestre em Engenharia. \\ Área de concentração: \\ Engenharia de Solos.
}

Orientador Fernando A. M. Marinho

\section{São Paulo}

2002 
Aos Meus Pais, os quais não mediram esforços para que eu chegasse até aqui. A eles que foram e são, os grandes responsáveis e incentivadores desta minha conquista. Os quais durante anos me ensinaram, que nesta vida a gente ganha, perde, luta, sorri, chora, sente amor, sente dor, adquire conhecimento e experiência. Com eles também aprendi que, só conquistamos nossos objetivos quando se tem 0 espírito de dedicação, persistência e fé. A vocês eu dedico esta minha vitória e conquista ao qual é o tão esperado fruto da semente que vocês plantaram e cultivaram durante estes anos. 


\section{Agradecimento}

Quero agradecer em primeiro lugar ao meu bom Deus e ao meu Anjo Especial que nunca se afastaram de mim principalmente nos momentos mais difíceis de minha vida, dos quais por várias vezes me carregaram no colo e afastaram de mim toda a insegurança e medo de não conseguir realizar e terminar este trabalho nem tão pouco termina-lo. Agradeço aos meus pais e familiares que foram os primeiros incentivadores, para a efetuação deste estudo, os quais estiveram sempre ao meu lado nos momentos de angustia, medo e dor. Agradeço ao meu orientador Fernando A. M. Marinho, pois sem sua orientação, ajuda e colaboração esta pesquisa não teria seu sucesso desejado e não teria chegado ao seu termino. Enfatizo aqui a figura ilustre do meu orientador, pelo fato do mesmo em várias ocasiões deixar seus afazeres e trabalho de lado, para poder estar me orientando e me conduzindo no exercício e conclusão desta árdua tarefa. Com o insigne professor e demais professores da USP aprendi muito, por isto a todos vocês minhas gratidões pela incansável dedicação. Quero dirigir os meus agradecimentos neste instante aos técnicos de laboratório, que estiveram sempre dispostos a auxiliar na realização dos ensaios, a vocês meu muitíssimo obrigado. Agradeço ainda a colaboração do ilustre Professor Alexandre Cabral e a relevante ajuda financeira da CAPES. Enfim obrigado à todos que de maneira direta ou indireta contribuíram para o bom êxito e realização deste importantíssimo e significante trabalho. 


\section{Sumário}

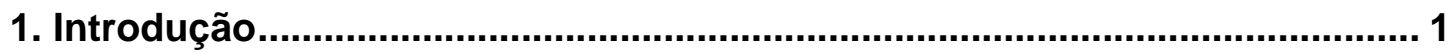

2. Objetivo

3. Experiências anteriores............................................................................... 6

3.1. Características gerais dos Resíduos de Papel ........................................... 6

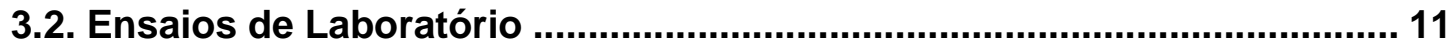

3.2.1. Determinação da umidade e do teor de matéria orgânica ...................... 11

3.2.2. Ensaio de Compactação ......................................................................... 17

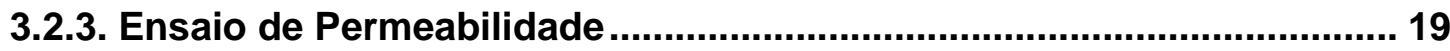

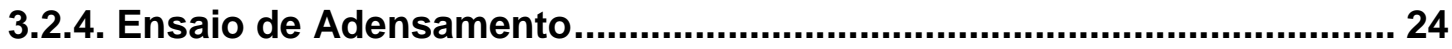

3.2.5. Ensaio de Resistência ao Cisalhamento .................................................. 29

3.2.6. Ensaio de Curva de Retenção ................................................................... 31

3.2.7. Efeito da decomposição da matéria orgânica na caracterização

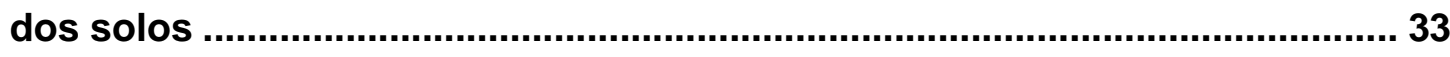

3.3. Considerações gerais para projeto de aterro utilizando o resíduo de

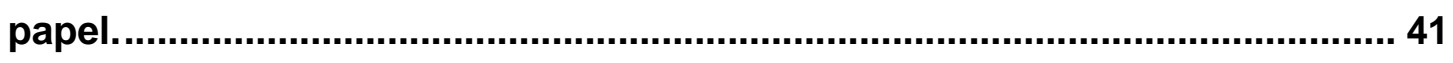

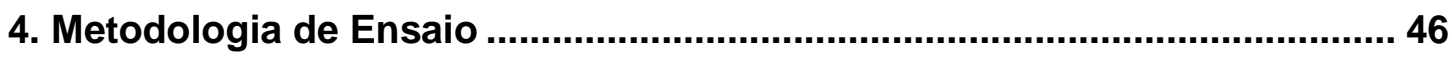

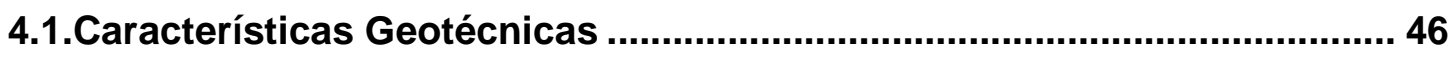

4.2. Determinação do Teor de Umidade e Teor de Matéria Orgânica .............. 48

4.3. Ensaio de Massa Específica dos Sólidos ................................................ 49

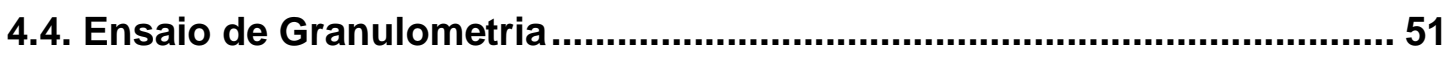

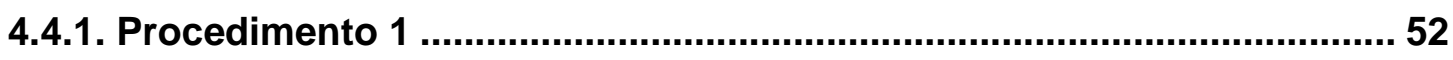

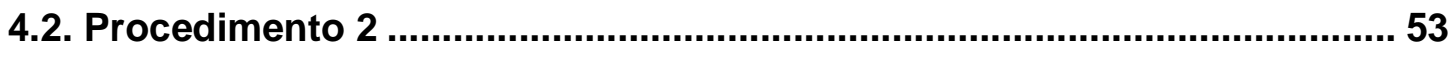

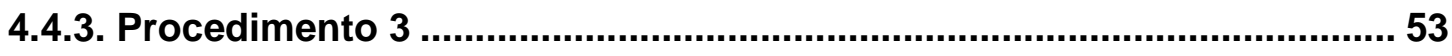

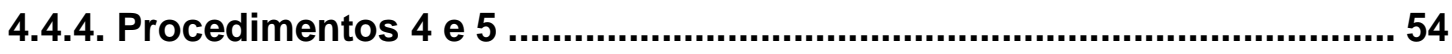




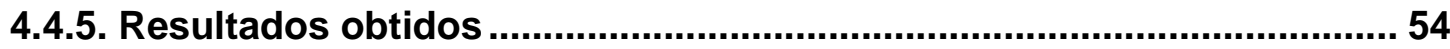

4.5. Ensaio de Limite de Consistência ............................................................ 59

4.5.1. Limite de Liquidez - Aparelho de Casagrande ...................................... 59

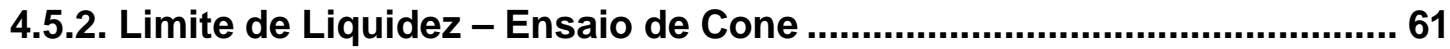

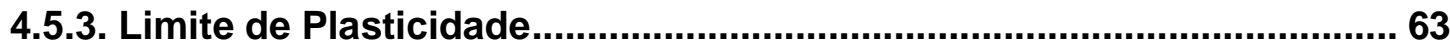

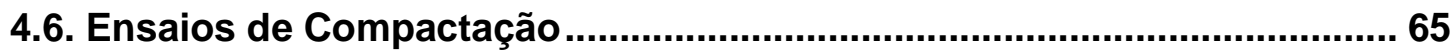

4.6.1. Ensaio de Compactação Proctor Normal .................................................. 65

4.6.2. Ensaio de Compactação Molde Reduzido ............................................... 69

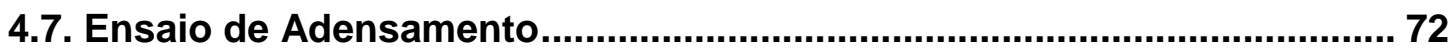

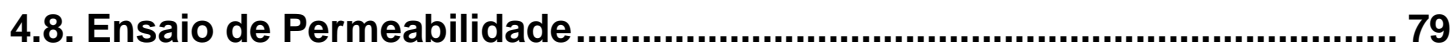

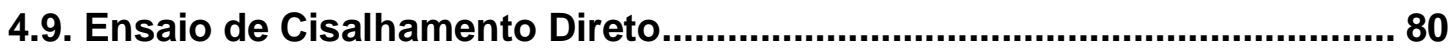

4.10. Determinação da Curva de Retenção ….................................................. 84

5.Comparação entre os resíduos da literatura e o resíduo da Rigesa. ...........90 90

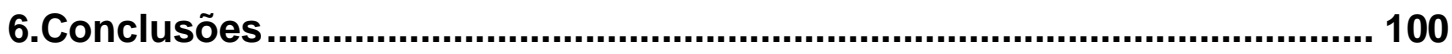

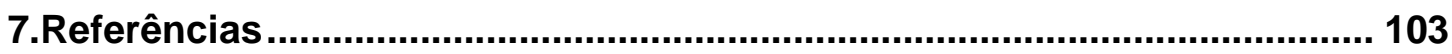




\section{LISTA DE FIGURA}

Figura 1 - Curva de redução de peso x temperatura (secagem de 12 horas) para

Fibras, Caolinita e Montimonilonita.

Figura 2 - Teor de matéria orgânica e densidade relativa dos grãos dos ensaios realizados por Moo-Young e Zimmie (1996)............................................. 15

Figura 3 - Ensaio de compactação Proctor Normal feito por Moo-Young e Zimmie (1996).

Figura 4 - Curva de compactação de Proctor Normal dos resíduos estudados por

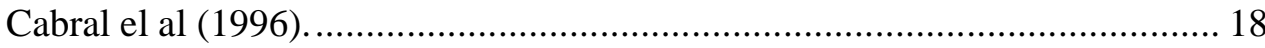

Figura 5 - Corpos de prova do ensaio de Proctor Normal (Cabral et al. 1996)....... 19

Figura 7 - Permeabilidade versus índice de vazios do resíduo (modificado de Cabral

et $\mathrm{al}, 1997)$..................................................................................... 21

Figura 8 - Resultados do ensaio teor de umidade de moldagem x permeabilidade feito Kraus et al (1997).......................................................................... 23

Figura 9 - Resultado do ensaio de adensamento para o resíduo "A" (Moo-Young e Zimmie, 1996)

Figura 10 - Gráfico do ensaio de adensamento tempo x recalque (Moo-Young e Zimmie,1996).

Figura 11 - Resultados encontrados para o resíduo $\mathrm{H}_{2}$ feitos por Andersland and Matheus (1973). 27

Figura 12 - Resistência ao cisalhamento pelo Vane teste $\mathrm{x}$ fração de matéria orgânica inicial (Al-Khafaji e Andersland ,1981).

Figura 13 - Curva de retenção de água estudada por Cabral et al (1996)................. 32

Figura 14 - Relação entre grau de saturação e sucção para o resíduo (adaptada Cabral et al, 2002). 33

Figura 15 - Diagrama esquemático dos sólidos orgânicos do solo antes e depois da decomposição.

Figura 16 - Teor de matéria orgânica versus índice de compressão para vários resíduos (Moo-Young e Zimmie, 1996)......................................................... 38

Figura 17 - Teor de matéria orgânica versus coeficiente de compressibilidade....... 39

Figura 18 - Teor de matéria orgânica versus permeabilidade (Moo-Young e

Zimmie, 1996).

Figura 19 - Perfil típico de um aterro utilizando resíduo de papel......................... 42

Figura 20 - Resultados do ensaio de palheta apresentados por Quiroz et al.(1998). 43

Figura 21 - Típico perfil utilizando resíduo de papel estudado por Cabral.

Figura 22 - Construção do aterro de Clinton utilizando resíduo estudado por Cabral

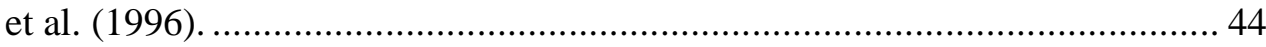

Figura 23 - Curva de compactação do resíduo estudado por Cabral et al. (1996).... 45

Figura 24 - Resíduo de papel da Rigesa secando ao ar. ........................................ 48

Figura 25 - Redução de peso e temperatura da estufa....................................... 49

Figura 26 - Ensaio de sedimentação do resíduo da Rigesa................................... 55

Figura 27-Curva granulométrica sem secagem e com uso de defloculante

(Procedimento 1) ................................................................................ 56

Figura 28 - Curva granulométrica sem secagem e sem uso de defloculante

(Procedimento 2) ....................................................................................... 56

Figura 29- Curva granulométrica com secagem e com uso de defloculante

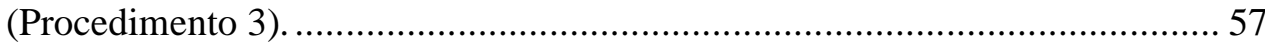


Figura 30- Curva granulométrica do resíduo da Rigesa (Procedimento $4^{\circ}$ )............ 57

Figura 31 - Curva granulométrica sem secagem e com uso de defloculante

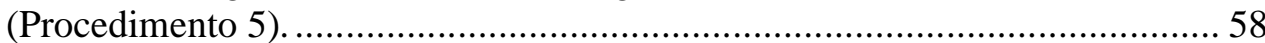

Figura 32 - Gráfico do limite de liquidez do resíduo da Rigesa.............................. 60

Figura 33 - Gráfico do limite de liquidez pelo método do cone para o resíduo da

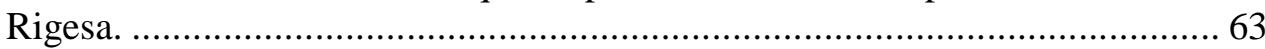

Figura 34 - Curva de compactação Proctor Nornal do resíduo da Rigesa................ 68

Figura 35 - Corpo de prova da Rigesa compactado do lado seco e do lado úmido. . 68

Figura 36 - Foto do equipamento do ensaio de compactação molde reduzido......... 70

Figura 37 - Ensaio de compactação proctor normal e molde reduzido. .................. 71

Figura 38 - Amostra da Rigesa no ensaio de adensamento após secagem em estufa.

Figura 39 - Curvas do ensaio de adensamento da amostra 1 da Rigesa.................. 75

Figura 40 - Curvas do ensaio de adensamento da amostra 2 da Rigesa................... 75

Figura 41 -Curvas do ensaio de adensamento da amostra 3 da Rigesa................... 76

Figura 42 - Curva do ensaio de adensamento amostra 4 ....................................... 77

Figura 43 - Curvas dos ensaios de adensamento amostra 5............................... 78

Figura 44 - Curvas dos ensaios de adensamento amostra 6................................ 78

Figura 45 - Resultados de ensaios de permeabilidade para as amostras de resíduo da

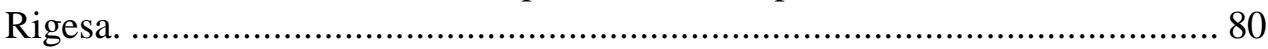

Figura 46 - Resultados do ensaio de cisalhamento direto do resíduo da Rigesa. ..... 82

Figura 47 - Envoltória de resistência obtida no ensaio de cisalhamento direto do

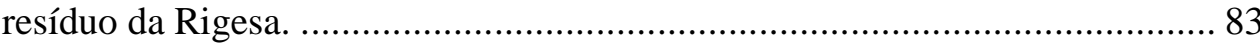

Figura 48 - Amostra da Rigesa após o ensaio de cisalhamento direto. .................... 83

Figura 50 - Esquema do Ensaio de Placa de Sucção do Laboratório de Solos da USP-

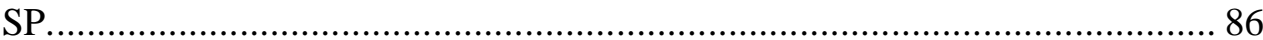

Figura 51 - Curva de retenção do resíduo da Rigesa............................................. 87

Figura 52 - Curva de retenção das amostras da Rigesa. ...................................... 89

Figura 53 - Relação entre a densidade relativa dos grãos e o teor de matéria orgânica.

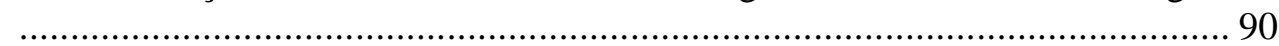

Figura 54 - Carta de plasticidade................................................................... 91

Figura 55 - Relação entre o teor de umidade ótimo e a densidade seca máxima...... 92

Figura 56 - Relação entre o grau de saturação na ótima e o teor de matéria orgânica.

Figura 57 -Envoltória de Resistência de alguns resíduos. .................................... 94

Figura 58 - Correlação entre Cc e teor de umidade inicial.................................... 96

Figura 59 - Relação entre o intercepto de coesão e o ângulo de atrito com o teor de

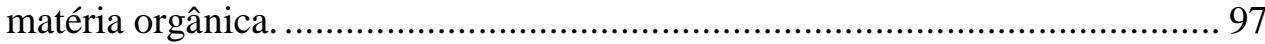

Figura 60 - Relação entre o índice de vazios e o coeficiente de permeabilidade...... 98 


\section{Lista de Tabela}

Tabela 1 - Nomenclaturas usadas e respectivas referencias. ................................... 7

Tabela 2- Características de produção dos resíduos de papel estudado por Moo-

Young e Zimmie et al (1996)...................................................................... 8

Tabela 3 - Composição químico-físico dos resíduos estudado por Cabral. ................ 9

Tabela 4 - Resumo das normas utilizadas para cada ensaio estudado por Moo-Young e Zimmie (1996), Cabral et al (1996) e outros.

Tabela 5 - Resumo dos Resultados de Ensaio feitos por Moo-Young and Zimmie (1996)

Tabela 6 - Propriedades básicas dos resíduos estudados por Cabral et al (1996).... 14

Tabela 7 - Propriedades do resíduo estudado por kamon et al (2000). ................... 15

Tabela 8 - Propriedades estudadas por Quiroz el al. ........................................... 15

Tabela 9 - Propriedade do resíduo de papel estudado por Andersland e Mathew. ... 16

Tabela 10 - Propriedade do resíduo de papel estudado por Kraus et al (1997). ....... 17

Tabela 11 - Resumo dos ensaios de cisalhamento do resíduo utilizado Zimmie...... 30

Tabela 12 - Resumo das normas utilizadas para o resíduo da Rigesa..................... 46

Tabela 13 - Procedimentos de ensaio para o ensaio de gramulometria. .................. 51

Tabela 14 - Resultados do ensaio de plasticidade. ............................................. 64

Tabela 15 - Características das amostras da Rigesa no ensaio de adensamento....... 73

Tabela 16 -Característica da amostra da Rigesa para o ensaio de adensamento....... 77

Tabela 17 - Características das amostras da Rigesa no ensaio de permeabilidade. .. 79

Tabela 18 - Características dos corpos de prova dos ensaios de cisalhamento direto.

Tabela 20 - Comparação entres resíduos estudados por Moo-Young e Zimmie (1996)

e Rigesa.

93

Tabela 21 - Comparação do índice de compressão encontrado no laboratório com correlações apresentadas por Wang et al. (1991) e Moo-Young e Zimmie (1996) 


\section{LISTA DE SÍMBOLO}

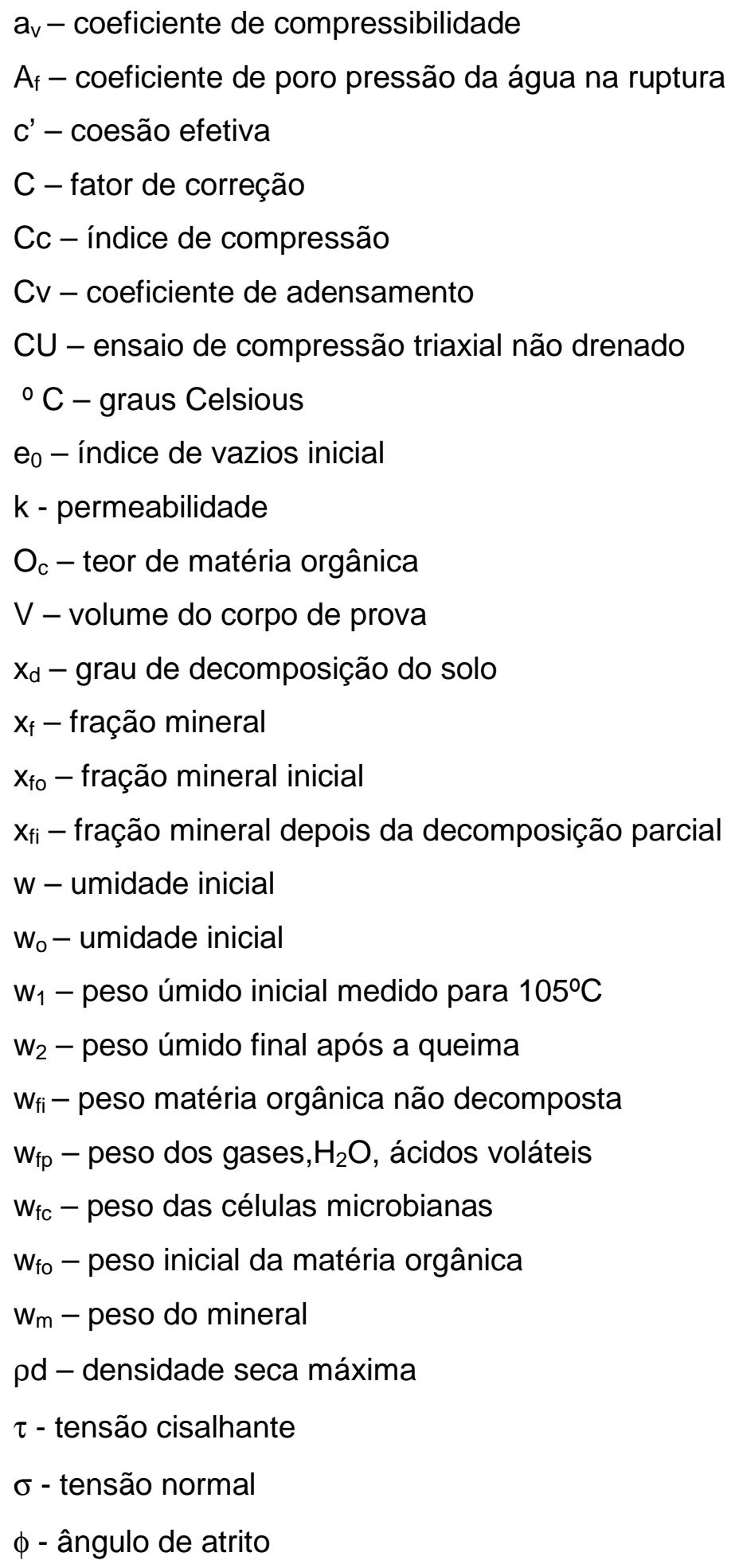




\section{Resumo}

A utilização de resíduos industriais gerados pela indústria de papel como material geotécnico, tem se tornado uma prática comum nestes últimos anos. Esta prática se dá devido a dois aspectos importantes: a economia e a aspectos ambientais. As indústrias de papel geram uma quantidade significativa de resíduos, e com o aumento dos custos de disposição e as dificuldades de armazenamento destes materiais está havendo uma preocupação crescente no reaproveitamento destes resíduos. O objetivo deste trabalho é apresentar as propriedades geotécnicas do resíduo de papel gerado pela indústria de papel Rigesa de Valinhos, São Paulo. O estudo deste tipo de resíduo pretende contribuir para redução do custo na disposição final do resíduo para as indústrias de papel e por outro lado oferecer uma alternativa econômica para o sistema de cobertura de outros resíduos. Este resíduo é gerado do lodo do sistema de tratamento de água residuária da indústria. $O$ resíduo é o lodo secundário do processo de tratamento na estação de reciclagem onde são fabricados caixas de papelão. O material apresenta um alto índice de matéria orgânica, um alto teor de umidade inicial e é altamente compressível. Neste trabalho são apresentados em detalhes os ensaios realizados com o resíduo. Salienta-se, no entanto, que os resultados obtidos envolvem aspectos relacionados com a metodologia de ensaio para este material. Desta forma, o presente trabalho pretende contribuir ainda para a adequabilidade dos ensaios convencionais a este resíduo. Os ensaios realizados foram: Limite de Atterberg, Densidade dos Grãos, Granulometria, Adensamento, Permeabilidade, Cisalhamento Direto, Placa de Sucção e Placa de Pressão. 


\begin{abstract}
The use of the residues generated by the paper industry as a geotechnical material, has become common practice in recent years. This practice is due to two important aspects: the economical and environmental aspects. The paper industry generates a significant amount of residue and with the increase of the costs related to the disposal of this material, there is a growing need to recycle. The objective of this work is to present the geotechnical properties of the paper residue generated by the Rigesa paper Industry in Valinhos, São Paulo. The study of this kind of residue intends to contribute to the reduction of the cost in the final disposal of the residue for the paper industry and, on the other hand, to offer an economic alternative for covering systems. This residue is generated from the sludges of the system of residuary water treatment of the industry. The residue is the secondary sludges of the process of the treatment in the recycling station where cardboard boxes are manufactured. The material presents a high organic content, a high initial water content and a high compressibility. This is presented in details through tests carried out with the residue. However, it should be pointed out that results obtained involve aspects related to the methodology of the test for this material. In this way the present work intends to contribute to the re-structuring of the conventional tests. The tests performed were: Limit of Atterberg, Specify Gravity, Grain Size Distribution, Consolidation, Permeability, Direct Shear, and the soil water Storage curve.
\end{abstract}




\section{Introdução}

A disposição de resíduos exige a utilização de sistemas de proteção que atendam não somente aos aspectos da geotecnia convencional, mas também àqueles relacionados com a proteção ambiental. Normalmente são utilizados como elementos da camada de proteção solos compactados e ou materiais geosintéticos. Esses materiais normalmente possuem elevado custo, possibilitando assim o estudo do uso de materiais não convencionais. Desta forma, o alto preço da disposição tem despertado interesse em desenvolver alternativas para o reuso dos resíduos gerados pela indústria de papel como material geotécnico.

O resíduo gerado pela indústria de papel possui uma grande quantidade de água e baixa quantidade de sólidos, sendo comparado com as argilas, em relação ao seu desempenho e comportamento como material de cobertura para aterro sanitário (e.g. Moo-Young \& Zimmie, 1996).

$\mathrm{Na}$ literatura corrente existem várias nomenclaturas para o resíduo gerado pela estação de tratamento da reciclagem do papel, tais como: lodo de papel, resíduo de papel, lama de papel, resíduo "deiking”. No presente trabalho o mesmo será referido como resíduo de papel ou simplesmente resíduo.

O presente apresenta a caracterização geotécnica do resíduo de papel resultante do tratamento de efluentes da indústria RIGESA, localizada na cidade de Valinhos, São Paulo. O objetivo é avaliar o uso desse resíduo como material de proteção superficial de depósito de outros resíduos ou para outros fins geotécnicos.

Como mencionada anteriormente, a valorização dos resíduos industriais é desejável, tanto do ponto de vista de contribuição da melhoria do meio ambiente como do ponto de vista econômico. Segundo a Rigesa, cerca de 1300 t. desse resíduo é produzido por mês na unidade de Valinhos. Este 
resíduo possui um elevado custo de armazenamento, pois ele é tratado como material sem valor comercial.

O uso específico do resíduo da indústria de papel como parte de sistemas de cobertura em depósitos de resíduos que produzem drenagem ácida tem sido fruto de estudo em vários países (e.g. Cabral et al. 1999).

A caracterização geotécnica do resíduo da indústria de papel é feita utilizando-se os conceitos dos ensaios usualmente aplicados a solos. $\mathrm{Na}$ literatura internacional encontram-se alguns dados geotécnicos de resíduos de papel em que se observa uma significativa variabilidade dos parâmetros geotécnicos (e.g. Zimmie \& Moo-Young, 1995, Cabral et al. 1998,1999,2000, Quiroz et al., 1997, Floes et al., Aloise and Alkinson 1990, Zimmie et al. 1993, 1996, 1997). As características geotécnicas dos resíduos de papel podem variar em função dos diferentes processos de produção do papel e dos vários tipos de processo de tratamento nas estações de reciclagem do papel.

O resíduo da Rigesa é gerado do lodo do sistema de tratamento de água residuária. O resíduo é o lodo secundário do processo da estação de tratamento onde são fabricados caixas de papelão.

Os resultados dos ensaios realizados com o resíduo da Rigesa indicam valores diferentes dos normalmente encontrados na literatura. Tais resultados indicam um material com maior capacidade de retenção de água, porém com grande capacidade de contração.

Salienta-se que os procedimentos e/ou interpretações dos ensaios normalmente utilizados nem sempre são aplicáveis ao resíduo. A classificação geotécnica para o resíduo de papel não é como a das argilas usadas em sistema de cobertura de aterro, embora, em geral o resíduo tenha um comportamento similar ao das argilas (Moo-Young and Zimmie, 
1996). Por exemplo, os Ensaios de Granulometria e de Limites de Atterberg são de difícil execução e interpretação devido às características do resíduo de papel e os resultados não podem ser manipulados em termos de classificação geotécnica (LaPlante, 1993 apud Moo-Young e Zimmie,1996). Estes aspectos também foram constatados nos ensaios realizados com o resíduo da Rigesa.

A compressibilidade do resíduo é um dos parâmetros geotécnicos mais importantes no projeto de um aterro quando se utiliza resíduo de papel como material de cobertura. $O$ índice de compressão do resíduo de papel é geralmente muito alto ( $C c \geq 1,20$, Zimmie et al, 1993) comparados com valores da argila natural (tipicamente entre 0,20 a 0,40, Lambe e Whitmam, 1969). Estas propriedades podem variar conforme a produção de papel de cada indústria, devido à variação de processos existentes nas estações de tratamento de reciclagem do papel e também com o estado de compactação do material.

A permeabilidade deste material varia em função do teor de umidade, grau de adensamento ou grau de compactação e idade do resíduo.

Dois aspectos são de fundamental importância para a utilização prática dos dados constante deste trabalho: As ações químicas e biológicas existentes no resíduo foram inibidas com uso de inseticida e foram desconsideradas neste trabalho. $\mathrm{O}$ uso deste resíduo está condicionado à manutenção das suas características no processo de geração do mesmo.

O trabalho foi dividido em sete capítulos. Após a apresentação do capítulo 2 faz-se uma revisão da bibliografia existente separando as informações de acordo com o tipo de parâmetro ou ensaio. As metodologias de ensaio utilizadas no presente trabalho são apresentadas no capítulo 4. No capitulo 5 são feitas comparações entre os dados existentes na literatura e os dados 
1. Introdução

obtidos com o resíduo da Rigesa. As conclusões e referências estão apresentadas nos capítulos 6 e 7, respectivamente. 


\section{Objetivo}

O objetivo principal do presente trabalho é determinar alguns parâmetros geotécnicos do resíduo de papel da Rigesa contribuindo assim para a compreensão do comportamento deste material sob o ponto de vista geotécnico.

Salienta-se, no entanto, que esta determinação envolve aspectos relacionados à metodologia de ensaios para este material. Desta forma, o presente trabalho também pretende contribuir para a adequabilidade dos ensaios convencionais para os resíduos de papel.

Objetiva-se ainda apresentar sugestões de uso para o material com base nos resultados obtidos e propor novas pesquisas visando o uso específico do resíduo da Rigesa. 


\section{Experiências anteriores}

\subsection{Características gerais dos Resíduos de Papel}

Encontra-se na literatura vários tipos de resíduo de papel onde são apresentados estudos sobre suas propriedades geomecânicas e sua utilização como barreira hidráulica em sistema de cobertura de aterro.

Vários pesquisadores apresentaram resultados de ensaio onde avaliam os parâmetros geotécnicos do resíduo de papel (e.g. Moo-Young e Zimmie (1996), Cabral et al. (1999), Kraus et al. (1997), Queiroz et al. (2000), Andersland e Mathew (1973)).

As diferenças nos resultados, muitas vezes encontrados entre os resíduos de papel, ocorrem devido aos diferentes processos industriais da própria fabricação do papel e dos vários tipos de processo de tratamento nas estações de rejeito de papel. Outros aspectos importantes a serem considerados nas comparações são as eventuais diferenças nos procedimentos de ensaios, que no caso do resíduo de papel podem afetar significativamente o resultado e a interpretação.

Com o objetivo de facilitar a interpretação dos dados das literaturas apresentam-se na Tabela 1 as nomenclaturas utilizadas nos artigos originais bem como seus respectivos autores e anos de publicação. 
3. Experiências Anteriores

\begin{tabular}{|c|c|}
\hline Nomenclatura & Referência \\
\hline$A$ & Moo-Young \& Zimmie, 1996 \\
\hline $\mathrm{B}$ & Moo-Young \& Zimmie, 1996 \\
\hline $\mathrm{C}_{1}$ & Moo-Young \& Zimmie, 1996 \\
\hline $\mathrm{C}_{2}$ & Moo-Young \& Zimmie, 1996 \\
\hline $\mathrm{C}_{3}$ & Moo-Young \& Zimmie, 1996 \\
\hline $\mathrm{D}$ & Moo-Young \& Zimmie, 1996 \\
\hline$E$ & Moo-Young \& Zimmie, 1996 \\
\hline KF 95/96 & Cabral et al (1999) \\
\hline KF 220197 & Cabral et al (1999) \\
\hline KF 040497 & Cabral et al (1999) \\
\hline PC 260597 & Cabral et al (1999) \\
\hline PC 150598 & Cabral et al (1999) \\
\hline KF 190698 & Cabral et al (1999) \\
\hline KF 030299 & Cabral et al (1999) \\
\hline PMS & Kamon et al (2000) \\
\hline A-MI & Kraus et al (1997) \\
\hline B-Ml & Kraus et al (1997) \\
\hline C-MA & Kraus et al (1997) \\
\hline NCASI-P & Quiroz et al (2000) \\
\hline NCASI-C & Quiroz et al (2000) \\
\hline IP & Quiroz et al (2000) \\
\hline Erving & Quiroz et al (2000) \\
\hline $\mathrm{H}_{2}$ & Andersland \& Mathew (1973) \\
\hline $\mathrm{H}_{3}$ & Andersland \& Mathew (1973) \\
\hline $\mathrm{Cl}-1$ & Andersland \& Mathew (1973) \\
\hline $\mathrm{Cl}-2$ & Andersland \& Mathew (1973) \\
\hline DS-1 & Andersland \& Mathew (1973) \\
\hline
\end{tabular}

Tabela 1 - Nomenclaturas usadas e respectivas referencias.

Um dos primeiros estudos com resíduo da indústria de papel é apresentado por Andersland e Mathew (1973). Eles estudaram o comportamento do 
resíduo de papel, onde $\mathrm{H} 2$ é o resíduo de papel no estado natural e H3 é resíduo de papel alterando o teor de matéria orgânica e quando combinando o resíduo com cal ou cinzas vulcânicas, o resíduo $C$ é a combinação do resíduo de papel da amostra 1 e 2 . Além de ensaios de caracterização foram feitos ensaios edométricos.

Moo-Young e Zimmie (1996) apresentam as propriedades geotécnicas do resíduo de papel produzido na fábrica Erving Papel Mill, em Massachusetts.

O estudo investigou as propriedades geotécnicas em sete resíduos de papel, nos quais foram realizados os ensaios de Limite de Atterberg, ensaio de Compactação, Cisalhamento Triaxial, Densidade Relativa dos Grãos, Permeabilidade e Adensamento.

Os resíduos utilizados para a pesquisa foram gerados conforme descreve a Tabela 2. Dentre os resíduos estudados por Moo-Young e Zimmie (1996) o resíduo "A" é o que mais se aproxima do da Rigesa.

\begin{tabular}{|c|l|}
\hline Resíduo & \multicolumn{1}{|c|}{ Métodos de produção do resíduo de papel } \\
\hline A & $\begin{array}{l}\text { Gerado da água servida da estação de tratamento de reciclagem do papel, } \\
\text { onde contem } 50 \% \text { de sólidos fixados e é composto de aproximadamente 50\% } \\
\text { de Caulinita e } 50 \% \text { de matéria orgânica. }\end{array}$ \\
\hline B & $\begin{array}{l}\text { Mistura de água servida da estação de tratamento de reciclagem do papel } \\
\text { misturado com esgoto da vizinhança. }\end{array}$ \\
\hline $\mathrm{C}_{1}$ & $\begin{array}{l}\text { Mistura de água servida da estação de tratamento de reciclagem do papel e } \\
\text { argila Caulinita, polpa de madeira e matéria orgânica com tempo de estocagem } \\
\text { de 1 ano. }\end{array}$ \\
\hline $\mathrm{C}_{2}$ & $\begin{array}{l}\text { Mistura de água servida da estação de tratamento de reciclagem do papel e } \\
\text { argila Caulinita, polpa de madeira e matéria orgânica com tempo de estocagem } \\
\text { de } 2 \text { a 4 anos. }\end{array}$ \\
\hline $\mathrm{C}_{3}$ & $\begin{array}{l}\text { Mistura de água servida da estação de tratamento de reciclagem do papel e } \\
\text { argila Caulinita, polpa de madeira e matéria orgânica com tempo de estocagem } \\
\text { de 10 a 14 anos. }\end{array}$ \\
\hline $\mathrm{D}$ & $\begin{array}{l}\text { Fluxo da primeira água servida da estação de tratamento da reciclagem do } \\
\text { papel, onde tem 55\% de sólidos fixados. }\end{array}$ \\
\hline $\mathrm{E}$ & $\begin{array}{l}\text { Fluxo gerado água servida da estação de tratamento de resíduo de papel onde } \\
\text { utiliza óxido titânio como matéria prima. }\end{array}$ \\
\hline
\end{tabular}

Tabela 2- Características de produção dos resíduos de papel estudado por

Moo- Young e Zimmie et al (1996). 
Cabral et al (1996) investigam o comportamento do resíduo de papel resultante do processo de reciclagem usado para clarear o papel (identificado pela industria como Office mix) de duas fábricas em Quebec, Canadá. Onde o resíduo é fruto de um processo aeróbico, o que contribui para a formação espontânea de fungos e isso ocorre em poucos meses após a recepção do material no laboratório. Para evitar o desenvolvimento de fungos e bactérias Cabral et al (2001) sugerem a adição ao resíduo um bactericida.

Este resíduo é composto em particular de Calcita e Caolinita, e matéria orgânica essencialmente de fibras de celulose. O resíduo é constituído de fibras altamente compressíveis, de aspecto esponjoso, com uma textura esmigalhada, tendo grande quantidade de tintura cinza.

$\mathrm{Na}$ Tabela 3 apresenta-se a composição físico-químico dos resíduos estudados por Cabral et al. (1996), onde se observa que os principais componentes do material são matéria orgânica voláteis, calcitas e metacaolinita. O material orgânico volátil principal é a celulose com átomos de carbono fonte para microorganismos.

\begin{tabular}{|c|c|c|c|c|c|c|}
\hline Resíduo & $\begin{array}{c}\text { Material } \\
\text { Orgânico } \\
\text { Volátil }\end{array}$ & Calcita & Metacaolinita & Talco & Rutilo & Outros \\
\hline KF 95/96 & 57,7 & 21,2 & 12,1 & 1,7 & 1,0 & 6,2 \\
\hline KF 97/98 & 62,9 & 21,1 & 8,4 & 2,0 & 0,7 & 5,0 \\
\hline PC 97/98 & 48,8 & 21,4 & 16,9 & 2,4 & 1,8 & 8,8 \\
\hline
\end{tabular}

Tabela 3 - Composição químico-físico dos resíduos estudado por Cabral.

Kamon et al (2000) investigaram as características geomecânicas do resíduo de papel denominado PS que é gerado da estação de tratamento da fabricação do papel manufaturado e desidratado em alta pressão. O resíduo 
estudado por eles contém matéria orgânica em quantidade significativa $(63,7 \%)$ e pode manter a plasticidade para alto teor de umidade.

Kraus et al (1997) estudaram o comportamento de três resíduos de papel. O resíduo denominado $\mathrm{A}-\mathrm{Ml}$ é uma combinação do resíduo primário do processo de clarificação do papel (identificado pela indústria como "deinking") e lama biológica da estação de tratamento. O resíduo B-MI é o resíduo primário do processo de fabricação de livros revestidos e sacolas revestidas, e papel sensível à pressão. O resíduo $C$ é a combinação do resíduo da fabricação de papel utilizado em roupas descartáveis, guardanapos e papel de seda.

Os resíduos foram estocados em depósitos refrigerados antes do seu uso para que não houvesse formação de bactérias biológicas e estas não mudassem as propriedades das amostras durante os ensaios programados. Os ensaios realizados por Kraus et al (1997) foram: caracterização, compactação, condutividade hidráulica de campo e laboratório. Ensaios de contração também foram executados.

Quiroz et al (2000) investigaram as propriedades de quatro resíduos de papel. Os resíduos NCASI - primário e NCASI - combinado são resíduos gerados da estação de tratamento das fábricas em Massachuretts. $O$ resíduo IP foi obtido da estação de tratamento da fábrica de papel International Paper Co.Inc. localizada em Corinth, NY e o resíduo Erving foi obtido da estação de tratamento da fábrica de papel Erving Paper Mills, Inc. localizada em Erving. MA. Esta fábrica é a mesma onde foram obtidos os resíduos estudados por Moo-Young e Zimmie (1996).

As normas utilizadas para execução dos ensaios nos resíduos NCASI e o estudado por Moo-Young e Zimmie et al (1996) e Cabral et al (1996) estão resumidas na Tabela 4 abaixo. 


\begin{tabular}{|l|l|}
\hline \multicolumn{1}{|c|}{ Ensaios realizados } & $\begin{array}{c}\text { Normas utilizadas para a execução dos } \\
\text { ensaios }\end{array}$ \\
\hline Determinação do teor de umidade & ASTM processo D 2974 \\
\hline $\begin{array}{l}\text { Determinação do teor de matéria } \\
\text { orgânica }\end{array}$ & ASTM processo D 2974 método C \\
\hline Determinação do limite de Atterberg & ASTM processo D 4318 \\
\hline Determinação do peso específico & ASTM processo D 854 \\
\hline $\begin{array}{l}\text { Determinação da Curva de } \\
\text { Compactação }\end{array}$ & ASTM processo D 698-78 \\
\hline Adensamento & ASTM processo D 2435 \\
\hline Permeabilidade & ASTM processo D 5084 \\
\hline Resistência ao Cisalhamento & ASTM processo D 4767 \\
\hline
\end{tabular}

Tabela 4 - Resumo das normas utilizadas para cada ensaio estudado por

Moo-Young e Zimmie (1996), Cabral et al (1996) e outros.

\subsection{Ensaios de Laboratório}

\subsubsection{Determinação da umidade e do teor de matéria orgânica}

O teor de umidade é um importante índice a ser analisado, pois ele afeta direta ou indiretamente a compactação, o adensamento, a resistência e a condutividade hidráulica do material (Moo-Young e Zimmie, 1996).

Para a determinação do teor de umidade nos ensaios realizados por MooYoung e Zimmie (1996) a temperatura da estufa variou entre $70^{\circ}$ a $105^{\circ} \mathrm{C}$. Esta variação de temperatura objetivou avaliar a queima de matéria orgânica e evitá-la quando o teor de umidade foi determinado. Para determinação do teor de matéria orgânica foi utilizado mufla, para queimar a matéria orgânica. A temperatura utilizada foi de $440^{\circ} \mathrm{C}$. Com isso a matéria orgânica é queimada resultando a Caolinita e o Talco que são os principais minerais dos resíduos.

A determinação direta da matéria orgânica requer a separação entre o solo inorgânico do solo orgânico. Para a engenharia, queimar os sólidos em alta 
temperatura é o método mais comum. A destruição da matéria orgânica pela queima assume que os outros constituintes do solo não sejam alterados.

Al-Khafaji e Andersand (1981) estudaram o efeito da temperatura na perda de peso de um solo argilo-fibroso. A Figura 1 apresenta a curva de redução de peso em função da temperatura para os componentes do solo, caolinita, e fibras. A curva mostra que para uma temperatura de $400^{\circ} \mathrm{C}$, mantida por 12 horas, obtém-se a perda mínima da superfície de hidratação da água para caolinita.

Os autores concluíram que a fração orgânica para o material em estudo é dado pela seguinte expressão:

$$
x_{f}=1-x_{m}=1-C\left(w_{2}-w_{1}\right)
$$

Onde: $x_{f}$ - é a fração orgânica

$x_{m}$ - é a fração mineral

$\mathrm{w}_{1}$ - o peso úmido inicial medido para $105^{\circ} \mathrm{C}$

$\mathrm{w}_{2}$ - o peso úmido final após a queima

$\mathrm{C}$ - fator de correção

O fator de correção depende da temperatura da queima. Para Al-Khafaji e Andersland (1981) este fator é $C=1,014$ para $400^{\circ} \mathrm{C}$ (para 12 horas de queima) ou $C=1,168$ para $900^{\circ} \mathrm{C}$ (para $1^{1 / 2}$ de queima). Arman (1970) recomenda que o teor de sólidos orgânicos deve ser determinado a $440^{\circ} \mathrm{C}$. 


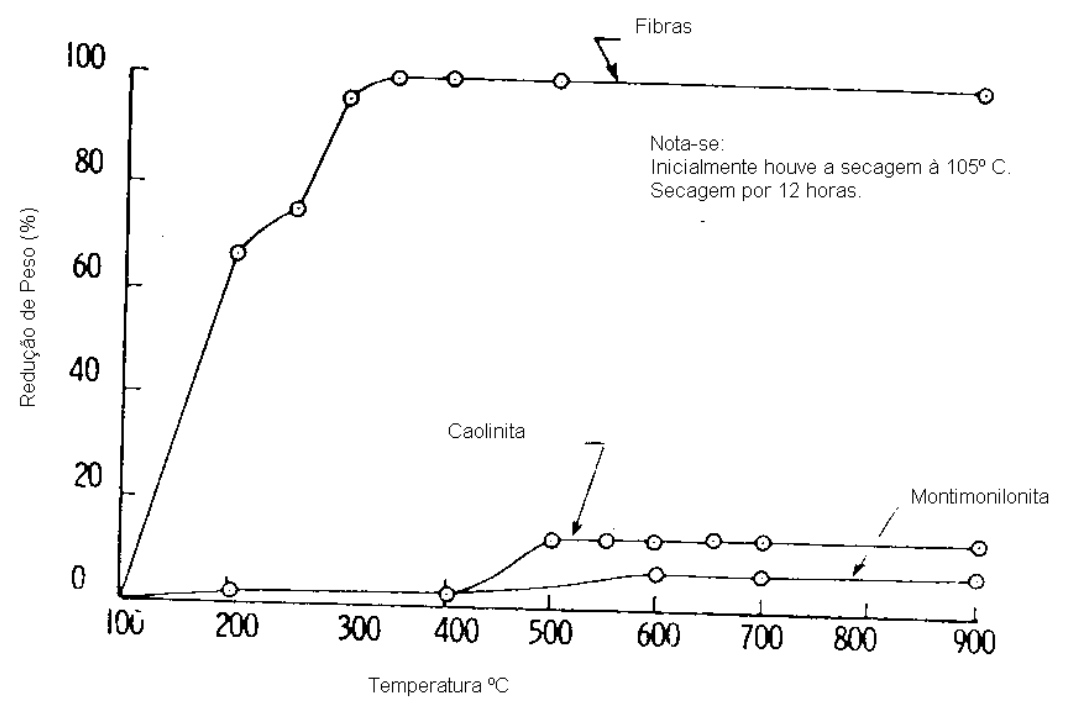

Figura 1 - Curva de redução de peso x temperatura (secagem de 12 horas) para Fibras, Caolinita e Montimonilonita.

Franklin, Orazco e Semrau (1973) admitem que mantendo a queima de $400^{\circ}$ a $450^{\circ}$ até a constância de peso obtém-se o teor de matéria orgânica. Skempton e Petley (1970) (apud Al-Khafaji e Andersland, 1981) concluíram que até 105 $\mathrm{C}$ ocorre a secagem dos sólidos orgânicos e a queima da matéria orgânica se dá a $500^{\circ} \mathrm{C}$. Para este pesquisador a fator de correção é $\mathrm{C}=1,04$ para $500^{\circ} \mathrm{C}$.

$\mathrm{Na}$ Tabela 5 são apresentados os dados obtidos por Moo-Young and Zimmie (1996) relativos a teor de umidade natural, teor de matéria, teor de caulinita, densidade relativa dos grãos, e os limites de Atterberg dos resíduos ensaiados por eles. 
3. Experiências Anteriores

\begin{tabular}{|c|c|c|c|c|c|c|c|}
\hline Resíduo & $\begin{array}{c}\text { Teor de } \\
\text { Umidade } \\
\text { Natural } \\
(\%)\end{array}$ & $\begin{array}{c}\text { Teor de } \\
\text { Matéria } \\
\text { Orgânica } \\
(\%)\end{array}$ & $\begin{array}{c}\text { Teor de } \\
\text { Caulinita } \\
(\%)\end{array}$ & $\begin{array}{c}\text { Densidade } \\
\text { relativa dos } \\
\text { Grãos } \\
(\mathrm{Gs})\end{array}$ & $\begin{array}{c}\mathrm{w}_{\mathrm{p}} \\
(\%)\end{array}$ & $\begin{array}{c}\mathrm{w}_{\mathrm{l}} \\
(\%)\end{array}$ & $\begin{array}{c}\mathrm{I}_{\mathrm{p}} \\
(\%)\end{array}$ \\
\hline $\mathrm{A}$ & $150-250$ & $45-50$ & 50 & $1,88-1,96$ & 94 & 285 & 191 \\
\hline $\mathrm{B}$ & $200-250$ & 56 & - & $1,83-1,85$ & 147 & 297 & 150 \\
\hline $\mathrm{C}_{1}$ & $255-268$ & $54-56$ & - & $1,80-1,84$ & - & - & - \\
\hline $\mathrm{C}_{2}$ & $180-200$ & $47-49$ & - & $1,90-1,93$ & 113,5 & 218 & 104,5 \\
\hline $\mathrm{C}_{3}$ & $220-240$ & $42-46$ & - & $1,96-1,97$ & 143 & 220 & 77 \\
\hline $\mathrm{D}$ & $150-200$ & 44 & - & $1,93-1,95$ & 137,5 & 255 & 117,5 \\
\hline $\mathrm{E}$ & $150-200$ & $35-40$ & - & $1,96-2,08$ & - & - & - \\
\hline
\end{tabular}

Tabela 5 - Resumo dos Resultados de Ensaio feitos por Moo-Young and

Zimmie (1996).

Os dados relativos aos teores de umidade e matéria orgânica, densidade dos grãos e teor de metacaulinita dos resíduos estudados por Cabral e colaboradores (1996) estão resumidos na Tabela 6.

\begin{tabular}{|l|c|c|c|c|}
\hline Resíduo & $\begin{array}{c}\text { Teor de Umidade } \\
\text { Natural } \\
(\%)\end{array}$ & $\begin{array}{c}\text { Teor de Matéria } \\
\text { Orgânica } \\
(\%)\end{array}$ & $\begin{array}{c}\text { Teor de } \\
\text { Metacaulinita } \\
(\%)\end{array}$ & $\begin{array}{c}\text { Densidade relativa } \\
\text { dos Grãos } \\
(\text { Gs })\end{array}$ \\
\hline KF 95/96 & $140-200$ & - & 12.1 & - \\
\hline KF220197 & 123 & 68,0 & 21,1 & 1,91 \\
\hline KF040497 & 124 & 61,5 & 21,1 & 1,95 \\
\hline PC260597 & 160 & 48,5 & 21,4 & 2.06 \\
\hline PC150598 & 90 & 46,6 & 21,4 & 2,09 \\
\hline KF190698 & 130 & 59,0 & 21,1 & 1,96 \\
\hline KF030299 & 126 & 60,9 & - & 1,94 \\
\hline
\end{tabular}

Tabela 6 - Propriedades básicas dos resíduos estudados por Cabral et al (1996).

Examinando-se as Tabelas 5 e 6, observa-se a esperada relação entre a densidade relativa dos grãos e quantidade de matéria orgânica. O resíduo que contém menor teor de matéria orgânica tem uma densidade relativa dos grãos mais elevada. O resíduo que contém menor teor de matéria orgânica tem uma grande quantidade de Caolinita. A Caolinita tem um peso específico entre 2,60 a $2,65 \mathrm{~g} / \mathrm{cm}^{3}$ e as fibras em geral tem um peso específico em torno de $1,5 \mathrm{~g} / \mathrm{cm}^{3}$, portanto, no resíduo que contém baixo teor de Caolinita ocorre uma diminuição na densidade relativa dos grãos. Moo-Young e Zimmie (1996) apresentam os resultado em forma de gráfico 
em que se pode observar a redução da densidade relativa dos grãos com o aumento do teor de matéria orgânica (Figura 2).

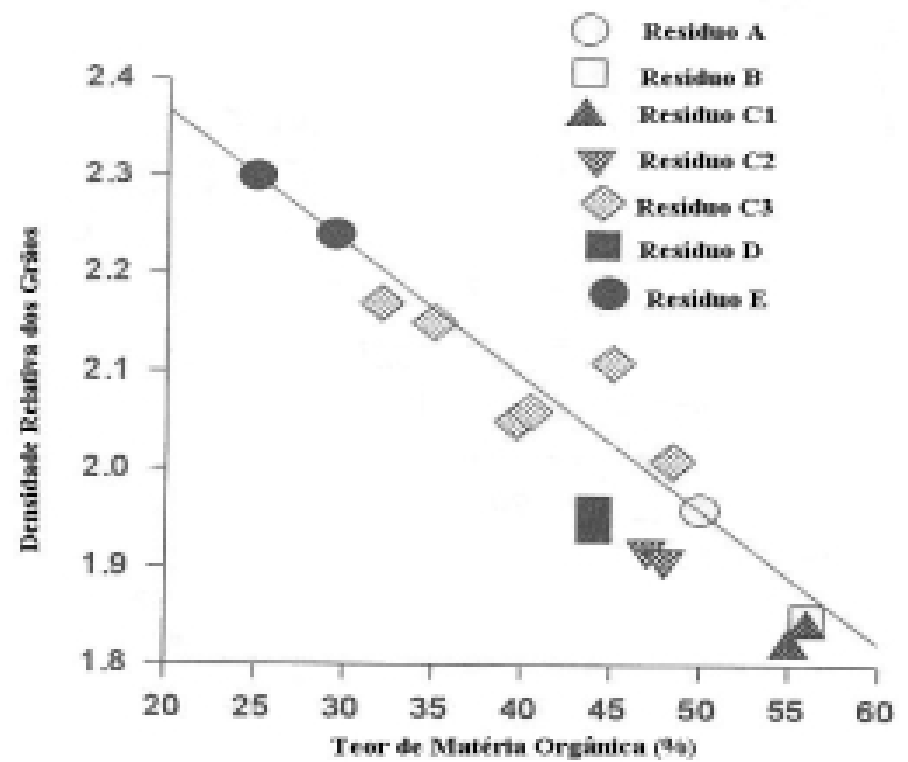

Figura 2 - Teor de matéria orgânica e densidade relativa dos grãos dos ensaios realizados por Moo-Young e Zimmie (1996).

Na Tabela 7 estão resumidas as propriedades do resíduo de papel estudado por Kamon et al (2000).

\begin{tabular}{|c|c|c|c|c|c|c|}
\hline Resíduo & $\begin{array}{c}\text { Teor de } \\
\text { Umidade Natural } \\
(\%)\end{array}$ & $\begin{array}{c}\text { Teor de Matéria } \\
\text { Orgânica } \\
(\%)\end{array}$ & $\begin{array}{c}\text { Densidade relativa } \\
\text { dos Grãos } \\
(\mathrm{Gs})\end{array}$ & $\begin{array}{c}\mathrm{w}_{\mathrm{p}} \\
(\%)\end{array}$ & $\begin{array}{c}\mathrm{w}_{\mathrm{l}} \\
(\%)\end{array}$ & $\begin{array}{c}\mathrm{I}_{\mathrm{p}} \\
(\%)\end{array}$ \\
\hline PSM & 132,5 & 63,7 & 1,79 & 106 & 352 & 246 \\
\hline
\end{tabular}

Tabela 7 - Propriedades do resíduo estudado por kamon et al (2000).

As propriedades dos resíduos investigadas por Quiroz et al. (1998) estão resumidas na Tabela 8 , onde também se observa o valor do peso específico seco do material na sua condição natural.

\begin{tabular}{|c|c|c|c|c|}
\hline Resíduo & $\begin{array}{c}\text { Teor de } \\
\text { Umidade Natural } \\
(\%)\end{array}$ & $\begin{array}{c}\text { Teor de Matéria } \\
\text { Orgânica } \\
(\%)\end{array}$ & $\begin{array}{c}\text { Densidade relativa } \\
\text { dos Grãos } \\
(\mathrm{Gs})\end{array}$ & $\begin{array}{c}\text { Peso Específico } \\
\text { Seco } \\
\left(\mathrm{KN} / \mathrm{m}^{3}\right)\end{array}$ \\
\hline NCAS-P & 182 & 48 & 1,92 & - \\
\hline NCASI-C & 222 & 51 & 2,07 & - \\
\hline IP & 240 & 59,8 & 1,92 & 3,49 \\
\hline Erving & 244 & 49,3 & 2,11 & 3,50 \\
\hline
\end{tabular}

Tabela 8 - Propriedades estudadas por Quiroz el al. 
Anderland e Mathew (1973) estudaram o comportamento dos resíduos de papel variando o teor de matéria orgânica. As características dos resíduos estudados por eles estão apresentadas na Tabela 9.

\begin{tabular}{|c|c|c|c|c|c|c|c|}
\hline Resíduo & $\begin{array}{c}\text { Teor de Matéria } \\
\text { Orgânica } \\
(\%)\end{array}$ & $\begin{array}{c}\text { Teor de } \\
\text { cinzas } \\
(\%)\end{array}$ & $\begin{array}{c}\text { Densidade } \\
\text { relativa dos } \\
\text { Grãos } \\
\text { (Gs) }\end{array}$ & $\begin{array}{l}w_{p} \\
(\%)\end{array}$ & $\begin{array}{c}w_{1} \\
(\%)\end{array}$ & $\begin{array}{l}I_{p} \\
(\%)\end{array}$ & $\begin{array}{c}w_{c} \\
(\%)\end{array}$ \\
\hline $\begin{array}{c}\mathrm{H}-2 \\
43 \% \text { teor } \\
\text { de } \\
\text { matéria } \\
\text { orgânica }\end{array}$ & 43,6 & 61,1 & 2,27 & 108,0 & 175,5 & 67,5 & 83,7 \\
\hline $\begin{array}{c}\mathrm{H}-2 \\
43 \% \text { teor } \\
\text { de } \\
\text { matéria } \\
\text { orgânica } \\
+10 \% \text { cal }\end{array}$ & 40,2 & 63,9 & 2,34 & 127,3 & 155,3 & 28,0 & 94,8 \\
\hline $\begin{array}{c}\mathrm{H}-2 \\
43 \% \text { teor } \\
\text { de } \\
\text { matéria } \\
\text { orgânica } \\
+10 \% \\
\text { cinzas }\end{array}$ & 39,9 & 64,7 & 2,20 & 113,5 & 162,1 & 48,6 & 82,1 \\
\hline $\begin{array}{l}\text { H3 } 40 \% \\
\text { teor de } \\
\text { matéria } \\
\text { orgânica }\end{array}$ & 40,4 & 54,7 & 2,14 & 103,3 & 174,4 & 71,1 & - \\
\hline $\begin{array}{l}\text { H3 31\% } \\
\text { Teor de } \\
\text { matéria } \\
\text { orgânica }\end{array}$ & 31,3 & 63,5 & 2,25 & 83,4 & 131,2 & 47,8 & - \\
\hline $\begin{array}{l}\text { H3 } 50 \% \\
\text { teor de } \\
\text { matéria } \\
\text { orgânica }\end{array}$ & 49,5 & 45,7 & 2,04 & 147,3 & 215,2 & 67,9 & - \\
\hline $\begin{array}{l}\text { H3 68\% } \\
\text { teor de } \\
\text { matéria } \\
\text { orgânica }\end{array}$ & 67,6 & 28,4 & 1,84 & 215,2 & 382,5 & 380,6 & - \\
\hline C-1 & 51,3 & 48,5 & 2,30 & 169,0 & 245,3 & 76,3 & 124,8 \\
\hline C-2 & 65,2 & 27,4 & 1,95 & 203,5 & 413,0 & 209,5 & - \\
\hline $\mathrm{D}-1$ & 56,8 & 35,7 & 2,01 & 141,6 & 325,4 & 183,8 & - \\
\hline
\end{tabular}

Tabela 9 - Propriedade do resíduo de papel estudado por Andersland e Mathew. 
Os dados relativos a teor de finos, teor de argila, teor de cinzas e comprimento das fibras dos resíduos estudados por Kraus et al (1997) estão apresentados na Tabela 10.

\begin{tabular}{|c|c|c|c|c|}
\hline Resíduo & $\begin{array}{c}\text { Teor de Finos } \\
(\%)\end{array}$ & $\begin{array}{c}\text { Fração de argila } \\
(\%)\end{array}$ & Teor de cinzas (\%) & $\begin{array}{c}\text { Comprimento das fibras } \\
(\mathrm{mm})\end{array}$ \\
\hline A & 59 & 41 & 56 & 0,24 \\
\hline B & 76 & 23 & 53 & 0,12 \\
\hline C & 80 & 36 & 44 & 0,29 \\
\hline
\end{tabular}

Tabela 10 - Propriedade do resíduo de papel estudado por Kraus et al (1997).

\subsubsection{Ensaio de Compactação}

Os ensaios de compactação realizados por Moo-Young e Zimmie (1996) com os resíduos descritos anteriormente foram executados do ramo úmido da curva para o ramo seco, isso se deve ao fato do material possuir um elevado teor de umidade inicial. A Figura 3 apresenta os resultados dos ensaios de compactação para os resíduos A, B, F, e G.

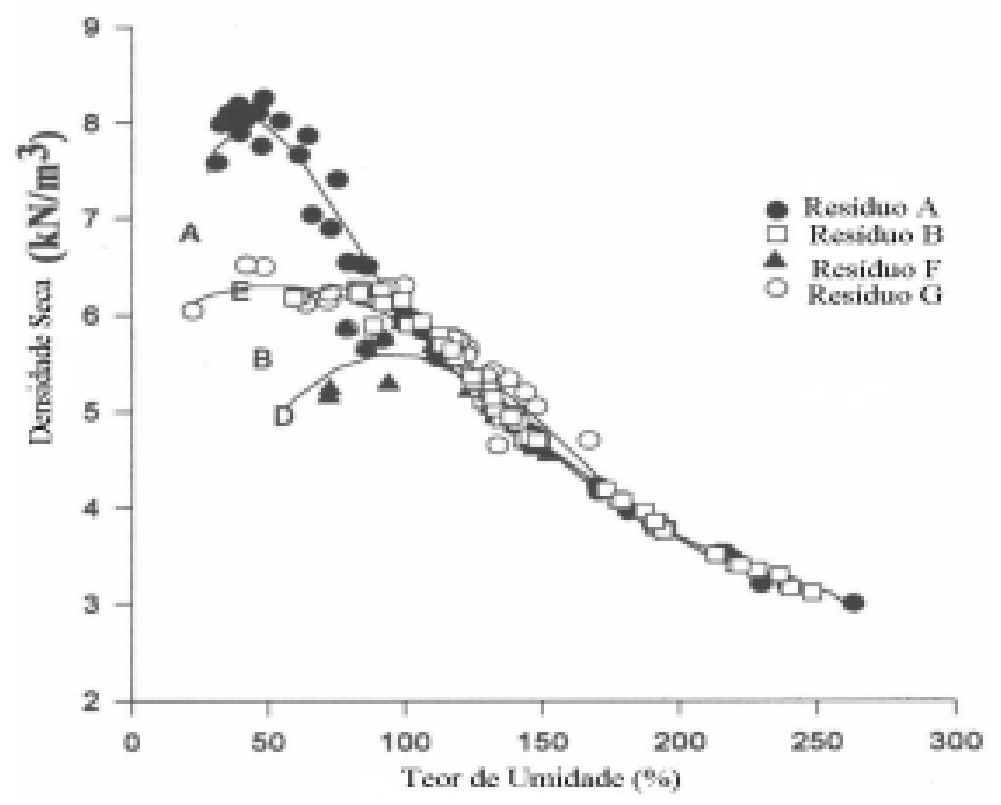

Figura 3 - Ensaio de compactação Proctor Normal feito por Moo-Young e Zimmie (1996). 
Os resíduos estudados por Cabral et al (1996) e Kraus et al (1997) também apresentaram as mesmas dificuldades encontradas por Moo-Young e Zimmie (1996), comentadas a seguir. A Figura 4 apresenta as Curvas de Compactação obtidas, onde a densidade seca máxima ( $\rho d$ ) variou de 510 $\mathrm{Kg} / \mathrm{m}^{3}$ a $680 \mathrm{Kg} / \mathrm{m}^{3}$, com teor de umidade ótimo ( $\mathrm{w}_{\mathrm{opt}}$ ) entre 55\% a 70\%.

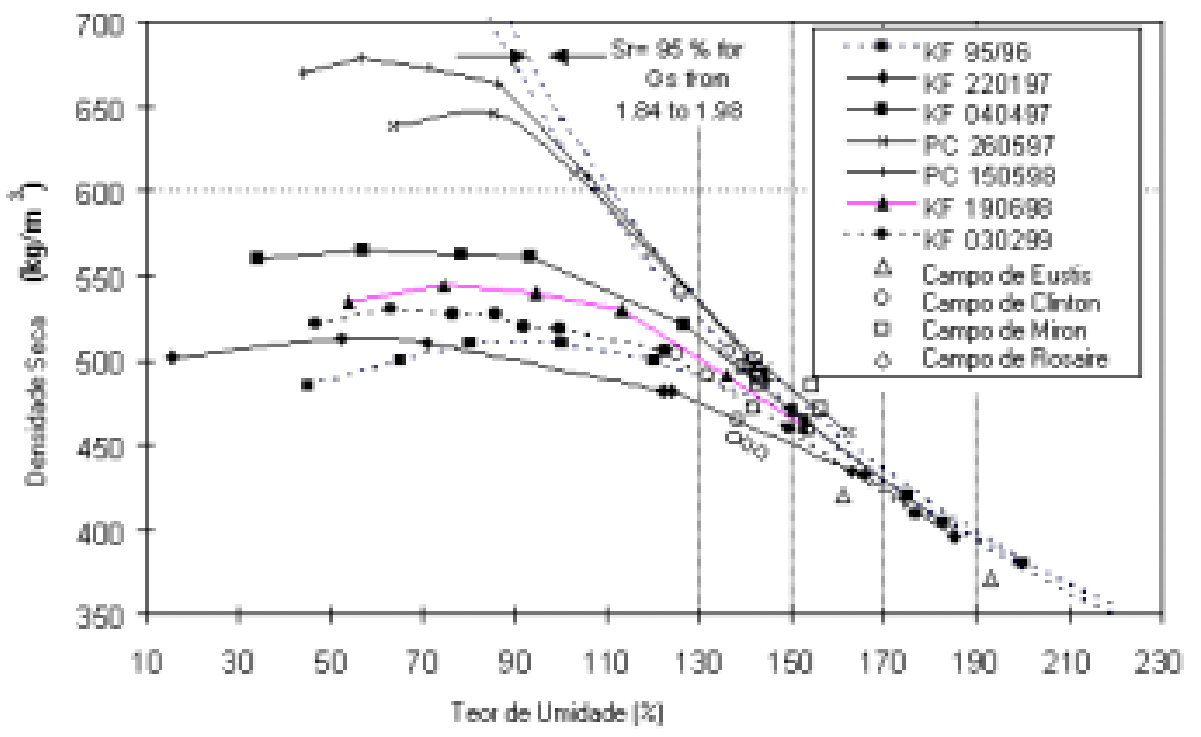

Figura 4 - Curva de compactação de Proctor Normal dos resíduos estudados por Cabral el al (1996).

Observando as curvas de compactação apresentadas nas Figura 3 e 4 percebemos a não definição do ramo seco e a aparente constância da densidade seca depois de um certo valor. Os resíduos que apresentam maior densidade seca foram os que apresentaram maior densidade relativa dos grãos e menor teor de matéria orgânica.

Na Figura 5 apresenta-se a fotografia dos corpos de provas do ensaio de Proctor Normal que foi feita por Cabral et al (1996). Estas amostras foram compactadas no lado seco e úmido em relação à ótima. Macro poros são evidenciados para a amostra compactada no lado seco (amostra da esquerda). 


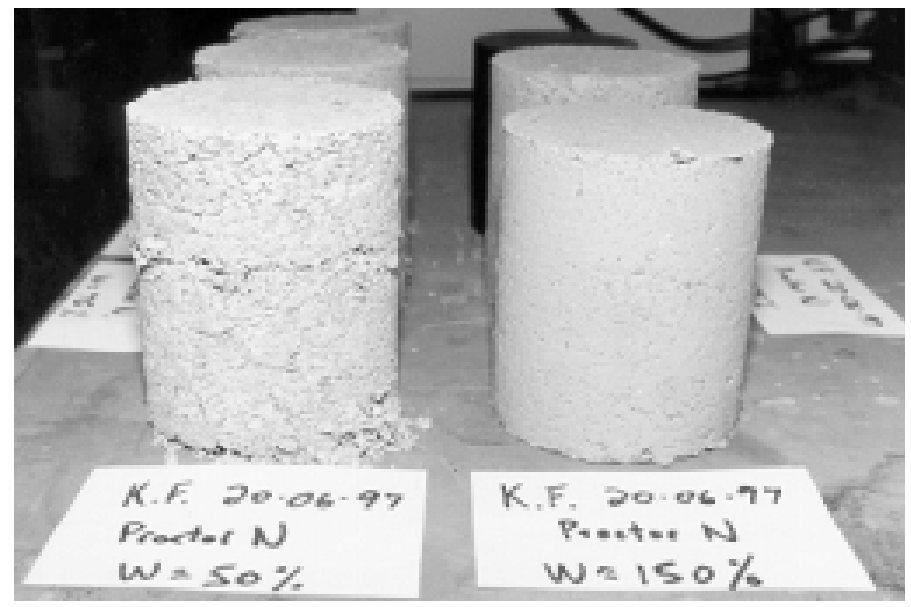

Figura 5 - Corpos de prova do ensaio de Proctor Normal (Cabral et al. 1996).

Kraus et al (1997) também observaram grandes índices de vazios nas amostras compactadas do lado seco em contraste com amostras compactadas do lado úmido da curva de compactação. As amostras compactadas do lado seco da curva de compactação apresentam torrões rígidos de difícil remoldagem. As amostras compactadas do lado úmido apresentam certa plasticidade, o que facilitava a remoldagem da amostra durante a compactação.

\subsubsection{Ensaio de Permeabilidade}

Os ensaio de permeabilidade foram executados para medir a condutividade hidráulica do material. Os resultados de permeabilidade executados nos resíduos de papel são altamente dependentes do teor de umidade na moldagem e são similares aos resultados obtidos em argila (LaPlante and Thomas, 1989, apud Moo-Young e Zimmie, 1996). 
Moo-Young (1993) realizou ensaio de permeabilidade em amostras de resíduo de papel compactas em uma ampla faixa de umidade. A menor permeabilidade ocorreu para um teor de umidade entre 50\% e 100\% acima do teor de umidade ótima. Na Figura 6 é apresentada a relação entre a permeabilidade e o teor de umidade de compactação obtido por Moo-Young (1993).

Moo-Young e Zimmie (1996) comentam que, quando se compacta o resíduo de papel para a construção de uma camada de cobertura com uma umidade próxima da umidade ótima obterá um material com alta permeabilidade e difícil trabalhabilidade.

Segundo Pinto (2000) "para umidades 2,5\% abaixo da ótima e densidade igual a 95\% da densidade máxima, por exemplo, o coeficiente de permeabilidade é cerca de 10 vezes maior do que na umidade ótima e densidade máxima. Para a mesma densidade, a permeabilidade diminui com o aumento do teor de umidade, apesar dos índices de vazios serem constantes e os dois corpos de prova ficarem com mesmo grau de saturação pelo efeito da própria água de percolação que aumenta a umidade do corpo de prova moldado mais seco". (Pinto, 2000, p.237)

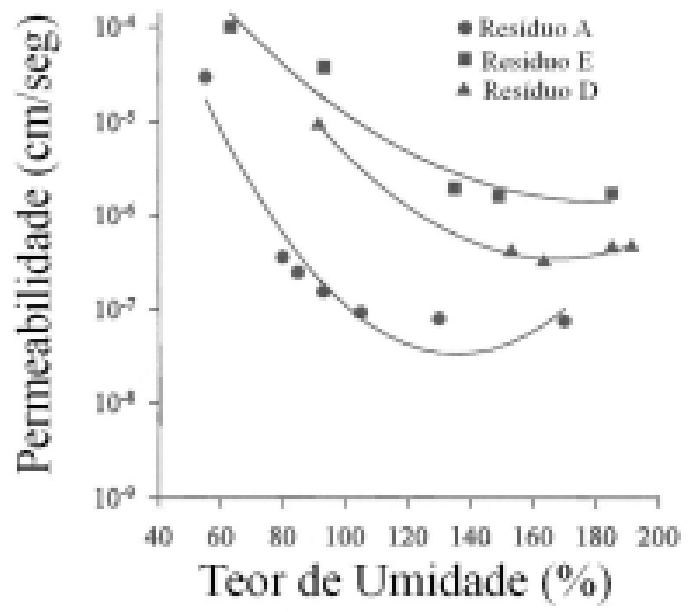

Figura 6 - Resultado teor de umidade x permeabilidade encontrados por Moo-Young e Zimmie (1996). 
Cabral et al (1996) avaliaram a permeabilidade pela média dos valores obtidos nos ensaios de adensamento. Incrementos de carga normal eram aplicados (12, 24, 48, $96 \mathrm{kPa}$ ), e os ensaios de permeabilidade de carga variável foram executados para cada tensão depois de permitir o adensamento por 24 horas. Os ensaios foram feitos em amostras com diferentes teores de umidade de moldagem e diferentes energias de compactação.

Os resíduos foram compactados com um teor de umidade de $50 \%$ a $60 \%$ acima da ótima objetivando-se atingir a mínima condutividade hidráulica (Krauss, et al,1997 e Cabral et al, 1997b). Na Figura 7 é apresentada a relação entre a permeabilidade e o índice de vazios, para um dos resíduos ensaiados por Cabral et al (1997), para vários teores de umidade de moldagem. Observou-se que o teor de umidade de moldagem é responsável pela variação de valor da permeabilidade.

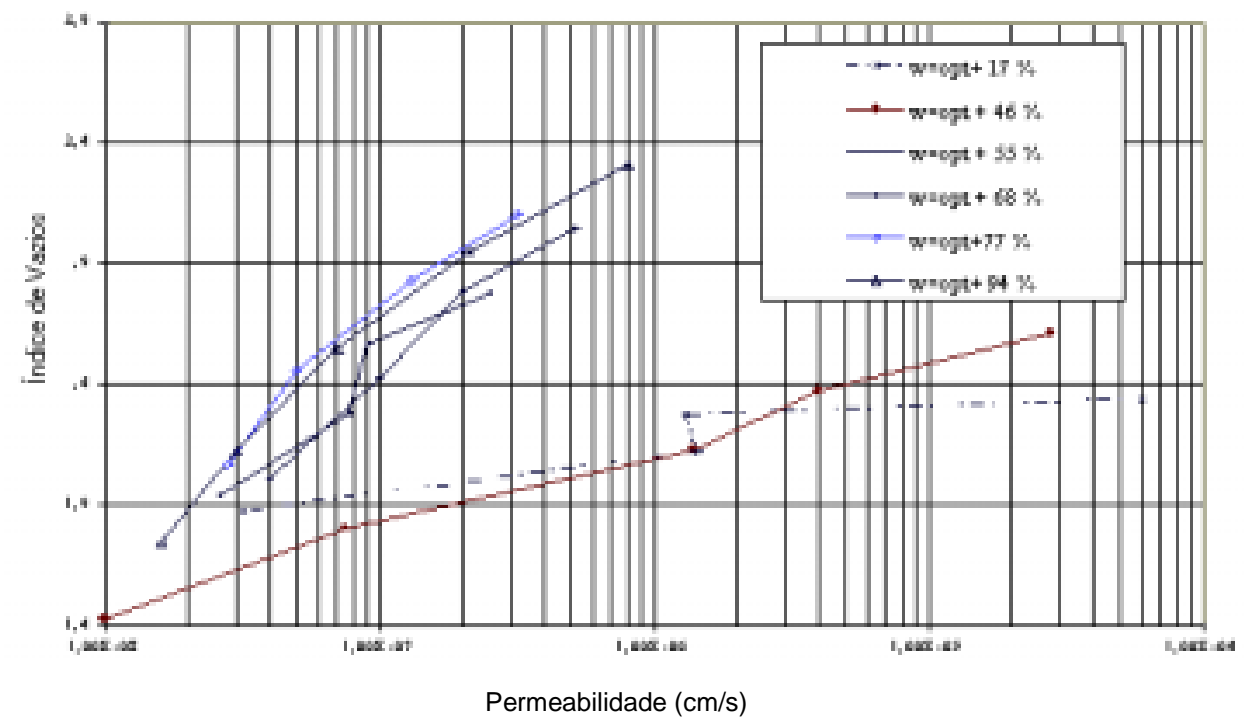

Figura 7 - Permeabilidade versus índice de vazios do resíduo (modificado de Cabral et al, 1997). 
Observa-se da Figura 7 que quando o teor de umidade de moldagem está aproximadamente $60 \%$ acima do teor de umidade ótimo, a influência do teor de umidade é menor. As curvas para diferentes teores de umidade tendem a se sobrepor. No caso das amostras com teores de umidade menor que $60 \%$ da umidade ótima, a permeabilidade apresentou-se significativamente maior, para o mesmo índice de vazios. Cabral et al (1996) atribuíram a isso compressão dos macro poros quando a amostra é compactada na umidade ótima. Moo-Young e Zimmie (1996a) concluíram que a permeabilidade para o resíduo de papel é fortemente dependente do teor de umidade de moldagem, do teor de matéria orgânica e do índice de vazios.

Kraus et al (1997) estudaram a relação do teor de umidade de moldagem e a permeabilidade. Os resultados obtidos por eles, para três resíduos, estão apresentados na Figura 8. Os autores concluíram que o comportamento do resíduo com relação à permeabilidade e teor de umidade de moldagem é similar ao das argilas compactadas. 

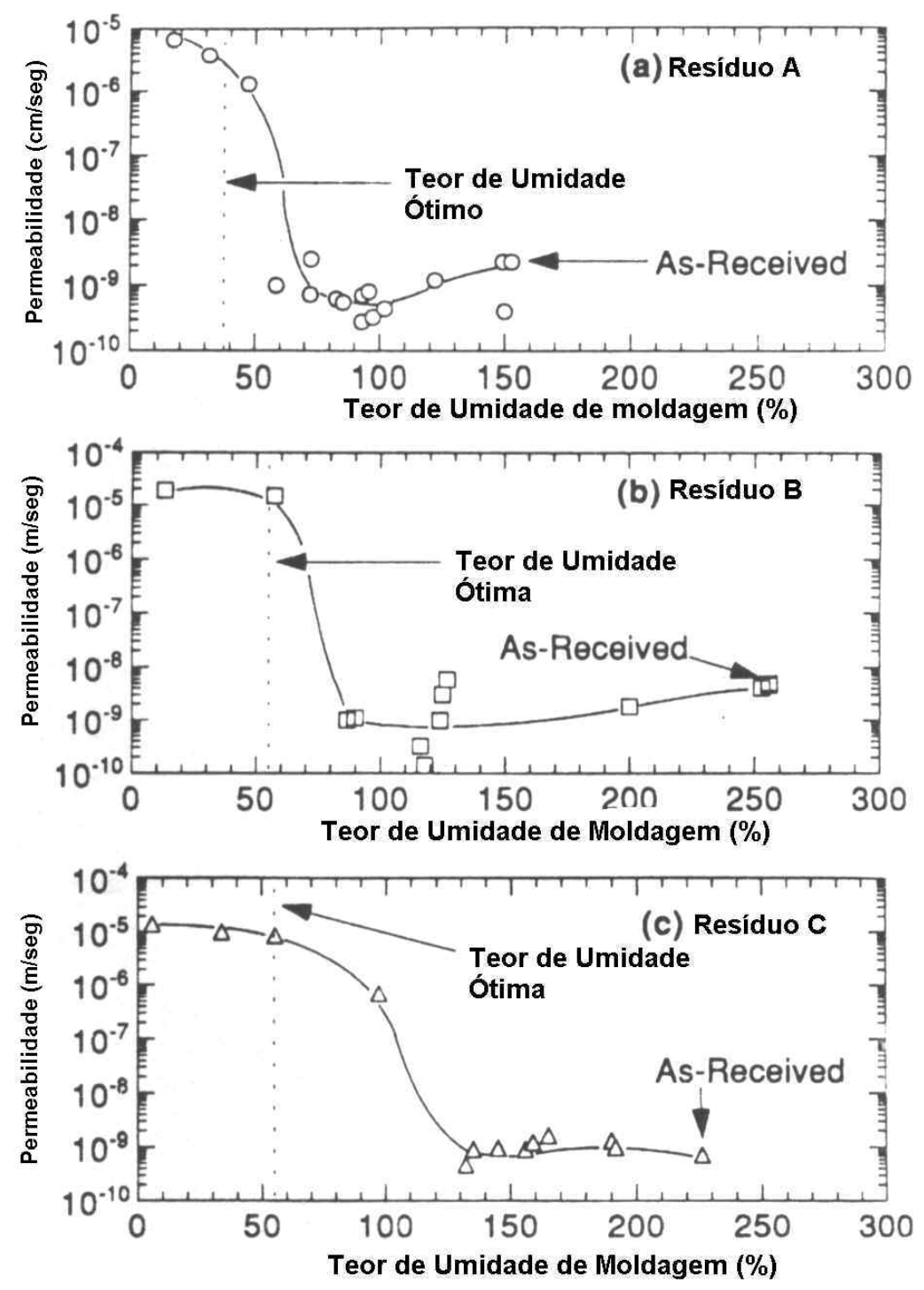

Figura 8 - Resultados do ensaio teor de umidade de moldagem $\mathrm{x}$ permeabilidade feito Kraus et al (1997).

A permeabilidade das amostras compactadas do lado seco foi quatro ordens de magnitude maior do que a das amostras compactadas do úmido. Essas variações na permeabilidade são coerentes com as diferenças na macro estrutura obtidas na compactação do lado seco e úmido da curva de compactação. A menor permeabilidade ocorreu de 50 a 100\% acima do teor de umidade ótima. 


\subsubsection{Ensaio de Adensamento}

Alguns estudos foram feitos para avaliar o comportamento $e$ as características de compressibilidade do resíduo de papel, tanto em campo como em laboratório (Moo-Young e Zimmie, 1996, Laudva e Charlei, 1976, Andersaland e Mathew 1973).

Através do ensaio de adensamento, Moo-Young e Zimmie (1996) observaram que os resíduos têm uma alta compressibilidade. O elevado teor de umidade inicial resulta em um índice de vazio inicial alto, tendo assim uma maior deformabilidade.

Com o objetivo de estudar a influência do teor de umidade na compressibilidade do resíduo "A", Moo-Young e Zimmie (1996) realizaram ensaios de adensamento com amostra remoldadas com vários teores de umidade. Foram executados 5 ensaios de adensamento onde o teor de umidade inicial variou entre 106 a 190\%. Na Figura 9 apresentam-se a variação do índice de vazios com a tensão efetiva aplicada. Observa-se que o índice de compressão (Cc) aumenta com o acréscimo do teor de umidade inicial. $O$ alto teor de umidade inicial pode resultar em um alto índice de vazios inicial.

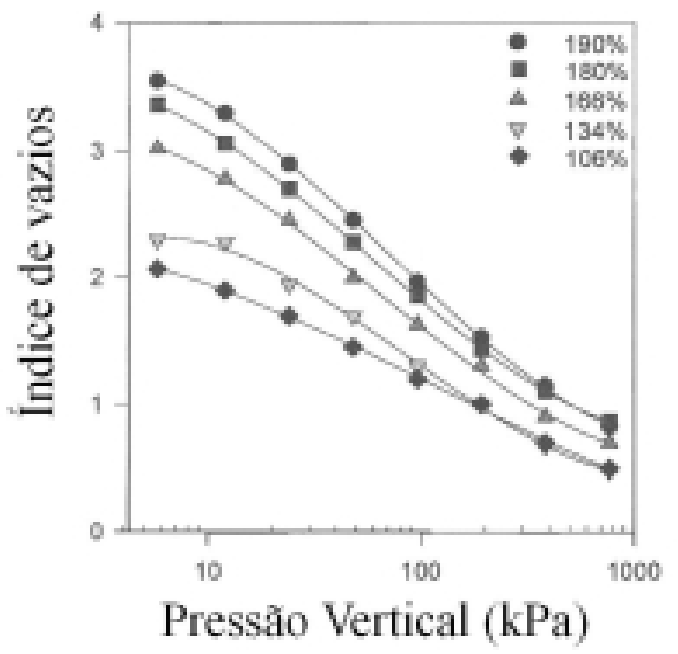

Figura 9 - Resultado do ensaio de adensamento para o resíduo "A" (MooYoung e Zimmie, 1996). 
Wang et al (1991) apresentaram uma correlação entre o teor de umidade inicial e o índice de compressão para resíduo de papel e lamas de estação de tratamento de água, que é apresentada a seguir:

$$
\mathrm{Cc}=0,009 \mathrm{w}_{0}
$$

Também é apresentada por Wang et al (1991) uma expressão que relaciona o índice de compressão com o índice de vazio:

$$
\mathrm{Cc}=0,39 \mathrm{e}_{0}
$$

Landva and LaRochelle (1983)(apud Wag et al, 1991) estabeleceram uma relação entre o índice de compressão e o teor de umidade para as turfas que são similares aos obtidos para os resíduos de papel.

Moo-Young e Zimmie (1996) calcularam os recalques previstos para o aterro municipal de Hubbardston executado com o resíduo A. Para um carregamento de $23,9 \mathrm{kPa}$, a deformação média apresentada no final do adensamento primário, definido pelo autor, foi de 16,5\%. O recalque previsto foi de $14,9 \mathrm{~cm}$. Segundo os autores, o adensamento secundário contribuiu com mais $3 \%$ de deformação que corresponde a um recalque de $17,8 \mathrm{~cm}$. Depois de um ano, o sistema de cobertura apresentou um recalque de 14 cm, e após dois anos, o recalque observado foi de $16,19 \mathrm{~cm}$.

Os autores comentam que no primeiro ano o recalque foi equivalente ao estimado com os dados do recalque primário, obtido dos ensaios de laboratório. No entanto para o segundo ano os autores consideram que o recalque do aterro foi semelhante ao previsto com os dados tanto do recalque primário como do secundário. (Figura 10). Os Autores concluem que as previsões baseadas nos ensaios de laboratórios fornecem uma boa indicação do comportamento do recalque. Uma análise mais detalhada dos 
dados de Moo-Young e Zimmie (1996) indicam que a forma de análise não é correta.

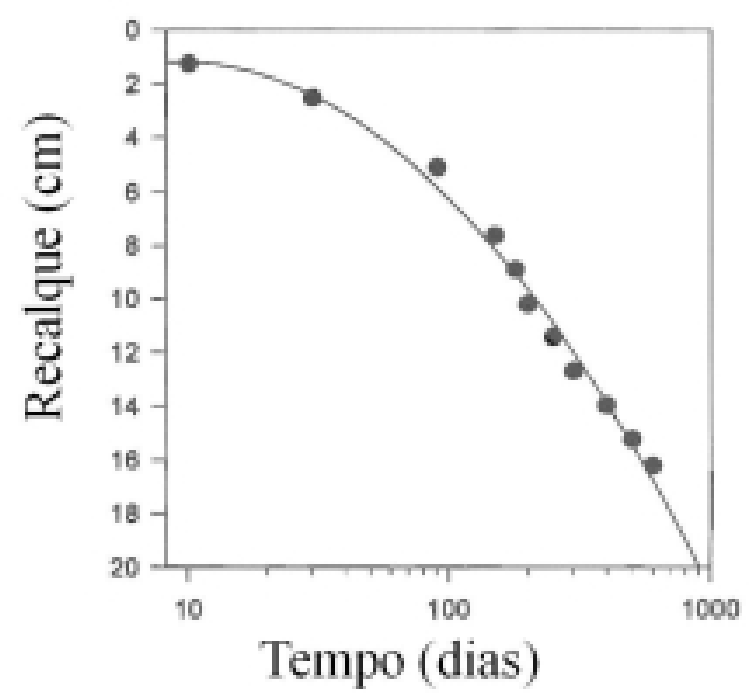

Figura 10 - Gráfico do ensaio de adensamento tempo x recalque (MooYoung e Zimmie,1996).

Para Day (1998), baseando-se na curva tempo versus recalque obtido por Moo-Young e Zimmie (1996) (Figura 10) o final do adensamento primário não parece ocorrer para $14,9 \mathrm{~cm}$ de deslocamento. Pode-se dizer também, que é difícil estabelecer se existe de fato uma separação clara dos fenômenos de adensamento primário e secundário.

Segundo Charlie et al (1979) (apud Quiroz et al, 2000), o processo de adensamento do resíduo de papel desenvolve-se com as mesmas características de um solo. Podendo ser separado em três categorias distintas, adensamento imediato, adensamento primário e adensamento secundário.

O adensamento imediato pode ser causado pelo gás ou ar existente na matriz do solo, compressão elástica do solo e água, tensão cisalhante ou a soma destes fatores. O adensamento primário é o resultado da dissipação 
do excesso de pressão nos poros devido a uma carga aplicada externamente. O adensamento secundário pode ser causado pelo deslizamento ou movimento relativo das partículas de solo, ou compressão das fibras dos orgânicos e decomposição da matéria orgânica ou todos os três efeitos. Métodos para avaliar a compressão secundária são apresentados por vários pesquisadores (e.g. Gibson e Lo 1961, Wahls 1962, MacFarlene 1969, Alkhafaji e Andersland 1981, Edil e Machtar 1984 e Stinnette 1998).

Andersland e Matheus (1973) realizaram ensaios de adensamento onde foi possível a medição de poro-pressão. As amostras foram preparadas em camadas diretamente no anel de adensamento. $O$ teor de umidade das amostras variou de $180 \%$ a $300 \%$. Foram feitos experimentos com diferentes relações de incrementos de carga. Usualmente o ensaio de adensamento utiliza uma relação entre o acréscimo de carga e a carga aplicada igual a um $((\Delta \mathrm{p} / \mathrm{p})=1)$. Os Autores realizaram ensaios com $(\Delta \mathrm{p} / \mathrm{p})$ variando de 0,25 a 1.

Na Figura 11 estão apresentados os resultados obtidos por Andersland e Matheus (1973) em que se pode observar a relação entre as leituras do extensômetro em função do tempo, para o resíduo $\mathrm{H} 2$.

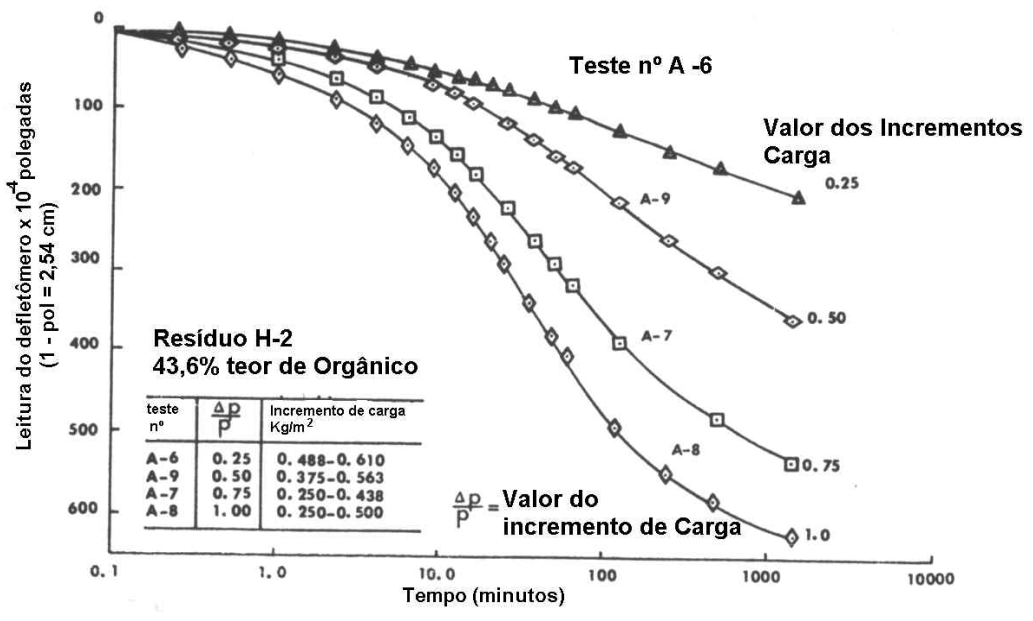

Figura 11 - Resultados encontrados para o resíduo $\mathrm{H}_{2}$ feitos por Andersland and Matheus (1973). 
Com base nos seus resultados Andersland e Matheus (1973) concluíram que:

1. o índice de compressão $\left(\mathrm{C}_{\mathrm{c}}\right)$ é independente da relação de incremento de carga utilizada;

2. o índice de compressão $\left(\mathrm{C}_{\mathrm{c}}\right)$ aumenta com o aumento do teor de matéria orgânica e com o aumento teor de umidade inicial;

3. quando é utilizada uma pequena relação de incremento de carga, fica difícil a separação do adensamento primário do secundário;

4. ao se utilizar uma pequena relação de incremento de carga $(\Delta \mathrm{p} / \mathrm{p})$ a dissipação de poro-pressão diverge da teoria do adensamento de Terzaghi, sendo mais rápida a dissipação do excesso de poropressão no resíduo até $80 \%$ do excesso da mesma. Além deste ponto a dissipação passa a ser mais lenta do que a prevista pela teoria. Quando se utiliza uma maior relação de incremento de carga a dissipação passa a concordar com a teoria de Terzaghi para valores até $70 \%$ do excesso de poro-pressão. Dessa forma os autores questionam a aplicação da teoria de adensamento para o resíduo de papel.

5. o coeficiente de adensamento (Cv) aumenta com a temperatura, ou seja, aumento na temperatura pode induzir maior compressão;

Al-Khafaji e Andersland (1981) realizaram ensaios de adensamento em equipamentos diferentes dos convencionais. O resíduo foi testado tanto na sua condição natural como com a adição de nutrientes e sementes, que objetivaram a aceleração do processo de decomposição. O material utilizado para o estudo foi uma mistura artificial de caolinita e fibras orgânicas. Embora o material estudado não seja um resíduo de papel, o seu comportamento pode ser comparado ao do resíduo de papel. As conclusões obtidas por Al-Khafaji e Andersland (1981) são: 
1. O recalque final em solos fibrosos pode ser previsto em termos de fração orgânica e incrementos de pressão utilizando-se o índice de vazios de equilíbrio (final).

2. O aumento do recalque como resultado da decomposição da matéria orgânica, pode ser previsto usando-se fração orgânica inicial e a decomposta para uma dada sobrecarga aplicada.

\subsubsection{Ensaio de Resistência ao Cisalhamento}

Moo-Young e Zimmie (1996) executaram ensaios de resistência ao cisalhamento nos resíduos A, B, E e F, definidos na Tabela 2. Os ensaios executados foram de compressão triaxial, adensados - não drenado (CU), com medida de poro pressão da água.

Os resultados obtidos indicam uma variação na coesão efetiva (c') de 2,8 a $9,0 \mathrm{kPa}$ e uma variação no ângulo de atrito ( $\left.\phi^{\prime}\right)$ de $25^{\circ}$ a $40^{\circ}$. Moo-Young e Zimmie (1996) também apresentam os valores do parâmetro de poro pressão da água na ruptura $A_{f}$. Os valores obtidos variaram entre 0,72 e 0,9. Day (1998) apresenta uma discussão sobre o trabalho de Moo-Young e Zimmie (1996) sobre o comportamento do resíduo. Os valores obtidos por Moo-Young e Zimmie (1996) sugerem que os resíduos ensaiados comportam-se como as argilas normalmente adensadas. Entretanto, os valores de coesão obtidos não indicam um material com características de um solo normalmente adensado. Além disso, os ângulos de atrito ( $\phi$ ') obtidos são muito alto e são valores típicos de solos granulares compactados. Day (1998) questiona assim, os valores elevados para o ângulo de atrito afirmando ser improvável que estes se apresentem com valores de $37^{\circ} \mathrm{e}$ $40^{\circ}$. Os resultados obtidos por Moo-Young e Zimmie estão resumidos na Tabela 11. 


\begin{tabular}{|c|c|c|c|}
\hline Resíduo & $\begin{array}{c}\text { Ângulo de Atrito } \\
\text { Interno Efetivo }\left(^{\circ}\right)\end{array}$ & $\begin{array}{c}\text { Coesão Efetiva } \\
(\mathrm{kPa})\end{array}$ & $\begin{array}{c}\text { Parâmetro } \mathrm{A}_{\mathrm{f}} \text { de } \\
\text { poro pressão }\end{array}$ \\
\hline A (teste 1) & 37 & 2,8 & 0,72 \\
\hline A (teste 2) & 25 & 9,0 & 0,74 \\
\hline B & 37 & 5,5 & 0,9 \\
\hline C3 & 32 & 9,0 & 0,7 \\
\hline D & 40 & 5,5 & 0,73 \\
\hline
\end{tabular}

Tabela 11 - Resumo dos ensaios de cisalhamento do resíduo utilizado Zimmie.

Durante a fase de adensamento, no ensaio triaxial, uma grande variação de volume ocorreu, o que já era esperado devido a grande compressibilidade do material.

Com relação à curva tensão deformação destes materiais observou-se que o ponto de ruptura era de difícil determinação. $O$ material não apresentou um ponto bem definido de ruptura. A ruptura foi, arbitrariamente, definida para uma deformação de $10 \%$. Caso outro valor fosse definido, os parâmetros de resistência seriam diferentes. As variações de resistência observada por Moo-Young e Zimmie (1996) foram atribuídas às variações no teor de umidade, as diferentes características de produção dos resíduos e ao teor de matéria orgânica. Eles consideram também que o teor de fibras afetam significativamente a coesão medida.

Al-Khafaji e Andersland (1981) estudaram a influência do teor de fibras na resistência ao cisalhamento. Para medir a resistência ao cisalhamento não drenado estes pesquisadores utilizaram o Vane Teste de laboratório. Assumindo uma variação linear da resistência ao cisalhamento com teor de matéria orgânica, os autores mostram a influência da tensão de adensamento nos materiais ensaiados. A Figura 12 ilustra os resultados obtidos. 


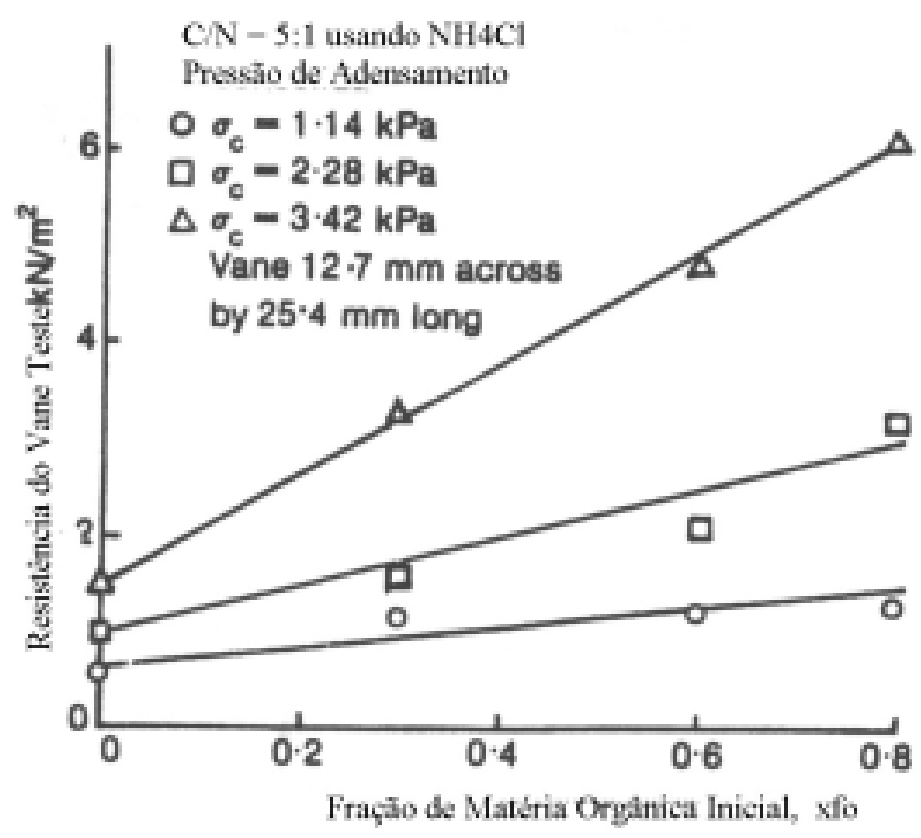

Figura 12 - Resistência ao cisalhamento pelo Vane teste x fração de matéria orgânica inicial (Al-Khafaji e Andersland ,1981).

Os pesquisadores concluirão que este aumento na resistência pode ser causado não somente pelo teor de matéria orgânica, mas também pelo comprimento das fibras, entrelaçamento das mesmas e o aumento da tensão de tração das fibras.

\subsubsection{Ensaio de Curva de Retenção}

Um outro aspecto de grande importância para a caracterização do resíduo de papel é estudar a sua capacidade de retenção de água. A obtenção da relação entre a quantidade de água e a sucção não é normalmente obtida para materiais porosos não orgânicos. No caso do resíduo de papel poucas informações são encontradas na literatura.

Cabral et al (1996) apresenta curvas de retenção, que relaciona o teor de umidade volumétrico com a sucção do material (Figura 13). Os dados foram obtidos utilizando-se um equipamento especialmente projetado para este fim 
e que utiliza a técnica da translação de eixos. Os resultados obtidos por Cabral et al (1996) indicam valores de entrada de ar entre 25 a $30 \mathrm{kPa}$. Esse parâmetro é importante para a caracterização do material para uso como barreiras capilares, pois ele define o ponto em que o material começa seu processo de dessaturação.

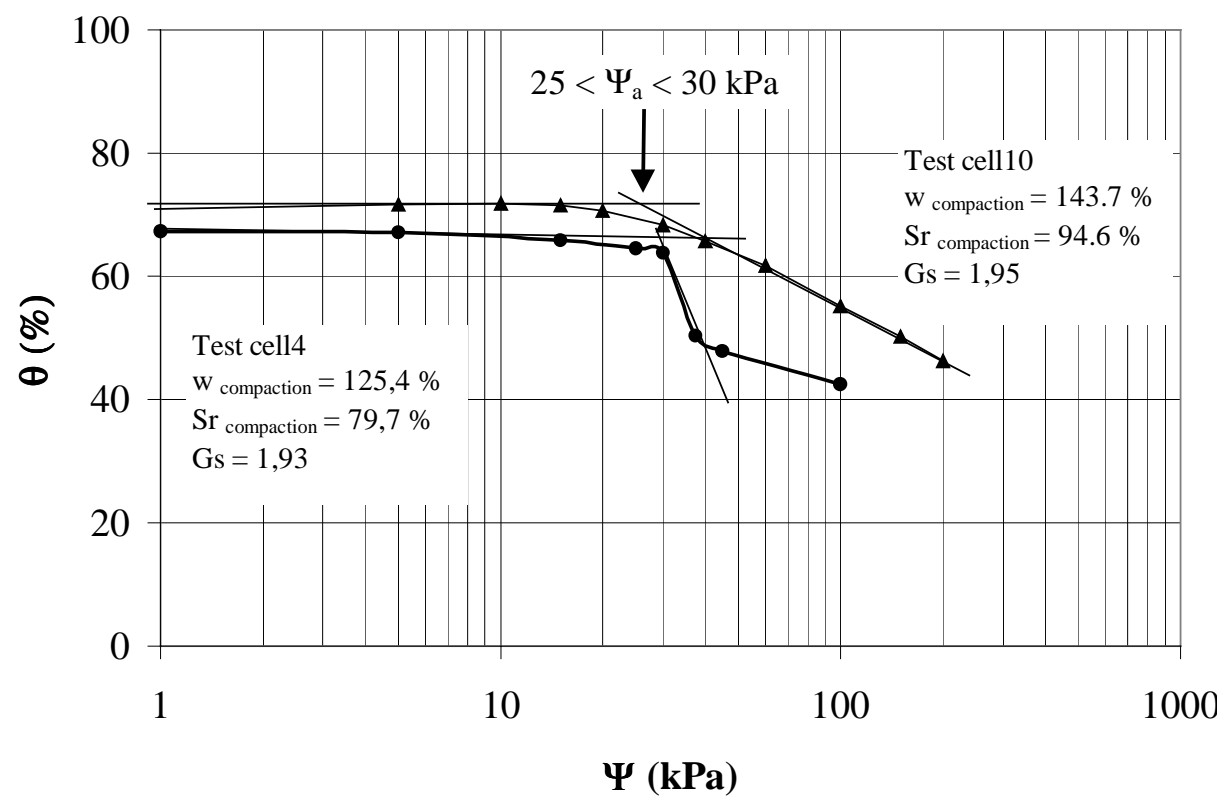

Figura 13 - Curva de retenção de água estudada por Cabral et al (1996).

A boa capacidade de retenção de água do material ajuda a manter o alto grau de saturação, que por sua vez reduz o fluxo de oxigênio $\left(\mathrm{O}_{2}\right)$ por difusão (Cabral et al, 2000).

Cabral et al (2002) apresentam curvas de retenção para o mesmo resíduo de papel usado pelos autores em trabalhos anteriores, além de outro resíduo com 10 anos de vida útil em um aterro. A curva de retenção é apresentada relacionando o grau de saturação de várias amostras com a sucção. Os resultados estão apresentados na Figura 14. Observa-se que para as amostras ensaiadas os valores de sucção de entrada de ar variaram entre $15 \mathrm{kPa}$ e $25 \mathrm{kPa}$. Com base nas informações fornecidas por Cabral et al (2002) pode-se concluir que: O nível de saturação necessário para manter a 
restrição ao fluxo de oxigênio é mantido em níveis satisfatórios no campo. Isto demonstra que o valor da entrada de ar do material é adequada para as condições climáticas do local onde o mesmo foi utilizado. Os autores consideram que a bio-degradação do resíduo, em dez anos, não afeta o comportamento do material.

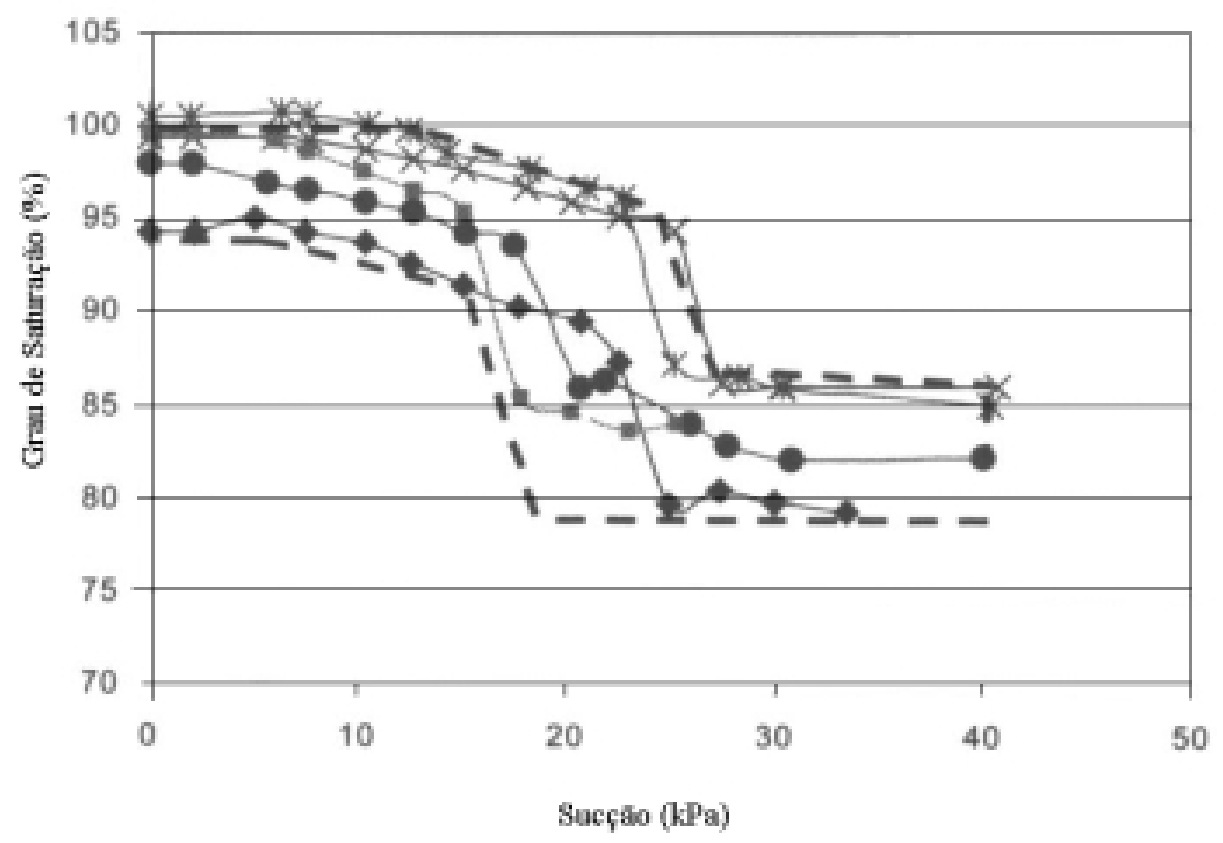

Figura 14 - Relação entre grau de saturação e sucção para o resíduo (adaptada Cabral et al, 2002).

\subsubsection{Efeito da decomposição da matéria orgânica na caracterização dos solos}

Problemas associados à decomposição dos solos orgânicos não são, na maioria das vezes avaliados pela engenharia por causa das incertezas das características dos solos orgânicos e a falta de informações do efeito da decomposição nas propriedades de engenharia. 
A decomposição dos solos argilo-fibrosos envolve a diminuição do volume dos sólidos orgânicos que em conseqüência afeta a compressibilidade e a resistência do material. Pode-se fazer uma avaliação do comportamento destes solos assumindo que o resíduo de papel tenha um comportamento semelhante.

A decomposição dos solos orgânicos envolve a perda e a transformação de resíduos de plantas e animais em húmus. Este processo é normalmente lento e muitas vezes ignorado para fins de engenharia.

Al-Khafaji e Andersland (1981a) induziram a decomposição de um solo argilo-fibroso artificial. O material é uma mistura de caulinita com fibras de celulose $(\mathrm{G}=1,54)$. Al-Khafaji e Andersland (1981a) prepararam uma mistura de caolinita e fibra de celulose, adicionaram água destilada até a formação de uma mistura com consistência de uma lama. Nutrientes e microorganismos em proporções pré-determinadas foram adicionados diretamente na mistura para acelerar a decomposição anaeróbica das amostras no laboratório. Foi utilizado teste de queima em estufa para medir o teor de matéria orgânica decomposta. Os autores realizaram estudos que demonstraram que o processo de medir a decomposição do teor de matéria orgânica decomposta dos solos orgânicos por queima em estufa é adequado, desde que alguns cuidados sejam tomados.

Ao se determinar o teor de matéria orgânica por queima em estufa, admitese que apenas a matéria orgânica é destruída na queima. Os demais componentes do material se manterão inalterados. Al-Khafaji e Andersland (1981a e 1981b) apresentam resultados da redução de massa dos componentes mais comuns nos solos em função da temperatura aplicada aos mesmos. Os autores mostram que existe a necessidade, em alguns casos, de se aplicar um fator de correção (C) que depende do tipo de material presente no solo. 
Al-Khafaji e Andersland (1981 a) concluíram que a determinação da fração orgânica $\left(\mathrm{x}_{\mathrm{f}}\right)$ para os solos argilo- fibrosos é obtida da seguinte forma:

$$
x_{f}=1-x_{m}=1-C\left(w_{2} / w_{1}\right)
$$

Onde: $x_{f}=$ a fração orgânica;

$x_{m}=$ fração mineral;

$\mathrm{w}_{1}=$ massa seca inicial da amostra secado a $105^{\circ} \mathrm{C}$;

$\mathrm{w}_{2}=$ massa final da amostra após a queima da matéria orgânica:

O valor de C para o material fibroso ensaiado por Al-Khafaji e Andersland (1981a) vale 1.014 quando a temperatura utilizada for de $400^{\circ} \mathrm{C}$ (durante $12 \mathrm{~h})$.

Com o objetivo de apresentar um procedimento para se medir a decomposição, Al-Khafaji e Andersland (1981b) apresentam um diagrama esquemático dos sólidos orgânicos antes e depois da decomposição (Figura 15).

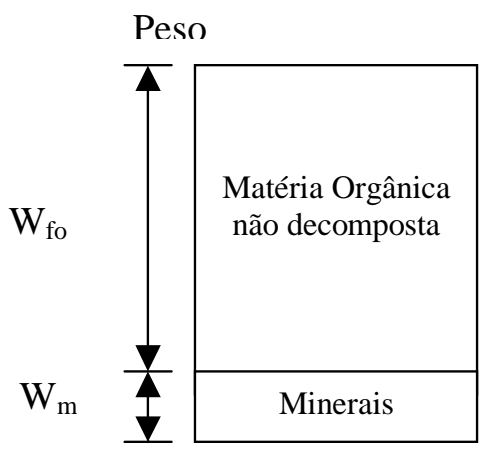

Condição Inicial

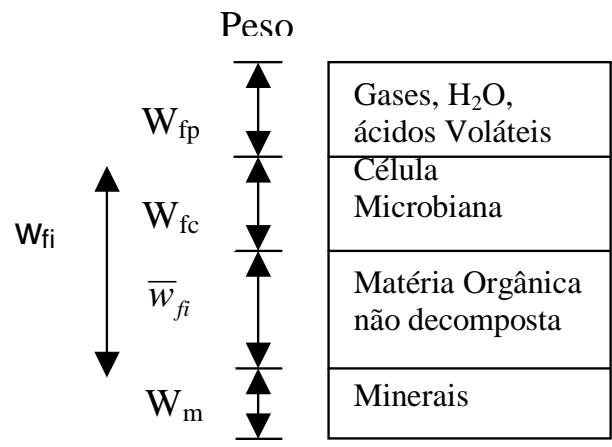

Decomposição Parcial

Figura 15 - Diagrama esquemático dos sólidos orgânicos do solo antes e depois da decomposição. 
Os autores consideram que seja razoável assumir que a perda de peso mostrada no esquema da Figura 15 possa ser usada como medida do grau de decomposição do solo $\left(\mathrm{x}_{\mathrm{di}}\right)$. Assim:

$$
\mathrm{X}_{\mathrm{di}}=\left(\mathbf{w}_{\mathrm{fo}}-\overline{w_{f i}}\right) \cdot\left(\mathbf{w}_{\mathrm{fo}}\right)^{-1}
$$

Onde: $w_{f o}$ é o peso inicial da matéria orgânica e $\overline{w_{f i}}$ é o peso da matéria orgânica não decomposta depois da decomposição parcial.

Separar a matéria orgânica do material inorgânico não é tão simples como mostrado na Figura 15. Define-se a fração de matéria orgânica inicial da seguinte forma:

$$
x_{f o}=w_{f o} /\left(w_{f o}+w_{m}\right)
$$

e a fração de matéria orgânica depois da decomposição parcial definida como:

$$
\mathrm{X}_{\mathrm{fi}}=\overline{w_{f i}} /\left(\overline{w_{f i}}+\mathrm{w}_{\mathrm{m}}\right)
$$

Onde: $w_{m}$ é o peso do material mineral;

Substituindo as equações 6 e 7 na equação 5 temos:

$$
X_{d i}=\left(1-\frac{X_{f i}}{X_{f o}}\right) \cdot \frac{1}{\left(1-x_{f i}\right)}
$$

Para a determinação de $\mathrm{x}_{\mathrm{fo}}$ e $\mathrm{x}_{\mathrm{fi}}$ usa-se o ensaio de queima estabelecendose assim o grau de decomposição do material.

O componente de decomposição dos solos orgânicos é dependente da contribuição dos nutrientes, umidade e temperatura. Os metabolismos e 
atividades dos microorganismos resultam em uma formação de dióxido de carbono, ácidos voláteis, gás metano, água, novas células de bactérias e uma diminuição no teor de sólidos orgânicos. Estas variações nos solos alteram drasticamente suas propriedades mecânicas num rápido período de tempo.

Moo-Young e Zimmie (1996) estudaram os efeitos da decomposição da matéria orgânica nas características do resíduo de papel. Os autores observaram que durante a estocagem do material ocorre um decréscimo no teor de matéria orgânica com o aumento da idade do resíduo de papel (ver Tabela 5 do item 3.2.1.). Este decréscimo no teor de matéria orgânica é resultado da decomposição biológica das fibras da matéria orgânica e dos tecidos que compõem o resíduo de papel com o tempo.

Os pesquisadores encontraram uma relação direta entre a densidade relativa dos grãos e o teor de matéria orgânica. Os resíduos contendo baixas porcentagens de matéria orgânica têm alta porcentagem de caolinita. Como em geral a caolinita tem um peso específico de $2,60 \mathrm{~g} / \mathrm{cm}^{3}$ a $2,65 \mathrm{~g} / \mathrm{cm}^{3}$ e as fibras têm um peso específico de $1,5 \mathrm{~g} / \mathrm{cm}^{3}$, o alto teor de fibras no resíduo diminui a sua densidade relativa. Portanto, diminuindo o teor de matéria orgânica aumenta a densidade relativa dos grãos, com visto na Figura 2 do item 3.1.1.

Em relação aos parâmetros de adensamentos Moo-Young e Zimmie utilizaram ensaios de adensamentos unidimensionais, com amostra contendo um teor de umidade variando de 109 a 224\%, com carregamento de 24 horas obtiveram uma relação entre o teor de matéria orgânica e a compressibilidade.

A Figura 16 apresenta a relação entre o índice de compressão e o teor de matéria orgânica para os vários resíduos estudados. Salienta-se que o coeficiente de correlação obtido pelos autores foi baixo $(0,47)$. 


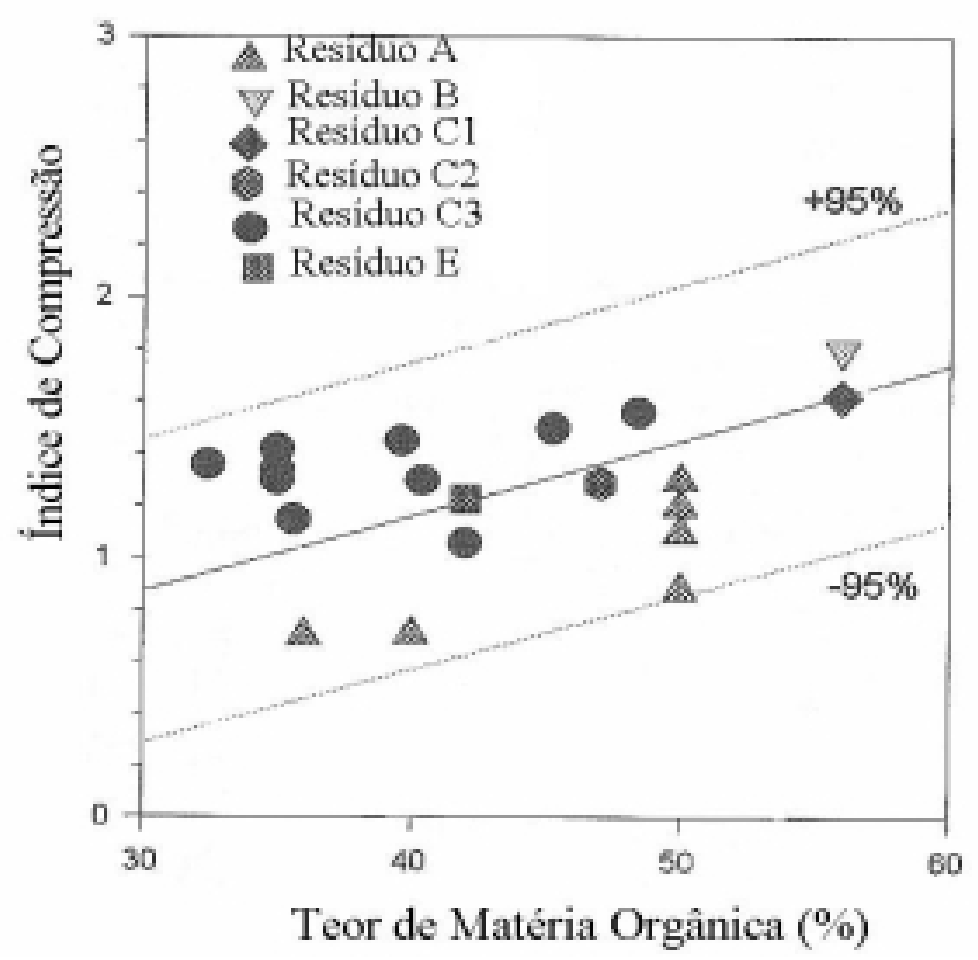

Figura 16 - Teor de matéria orgânica versus índice de compressão para vários resíduos (Moo-Young e Zimmie,1996).

A relação entre o índice de compressão e $\left(\mathrm{C}_{c}\right)$ e o teor de matéria orgânica (Oc\%) obtida com base nos resultados da figura 16 é a seguinte:

$$
\mathrm{C}_{\mathrm{c}}=0,027 \mathrm{Oc}
$$

A Figura 17 mostra o coeficiente de compressibilidade $\left(a_{v}\right)$ e $\circ$ teor de matéria orgânica $(\mathrm{Oc})$ para os vários resíduos de papel. A relação do coeficiente de compressibilidade $a_{v}\left(m^{2} / k N\right)$ e o teor de matéria orgânica Oc (\%) é dada pela expressão:

$$
a_{v}=0,000274 \text { Oc }
$$


3. Experiências Anteriores

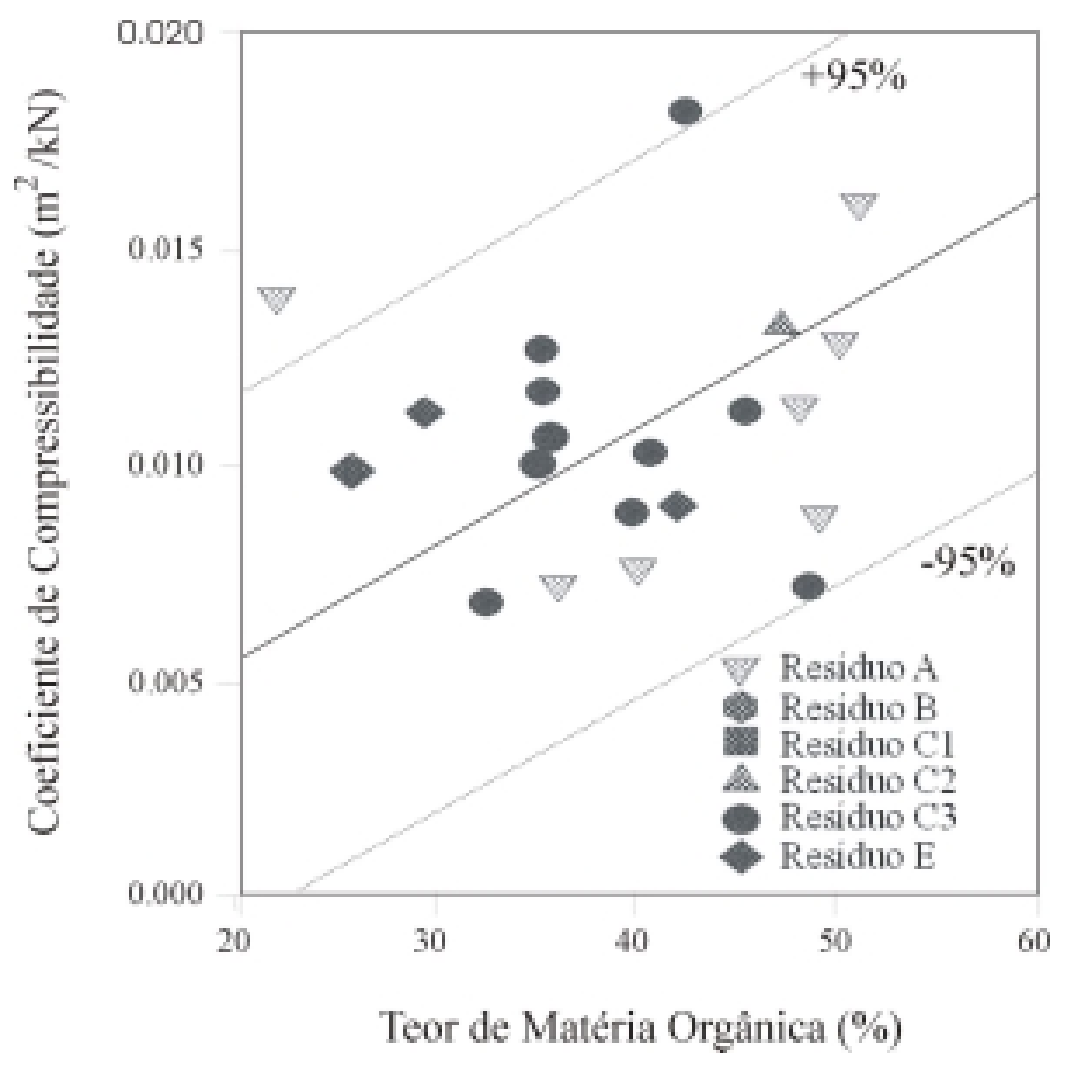

Figura 17 - Teor de matéria orgânica versus coeficiente de compressibilidade.

Moo-Young e Zimmie (1996c) também estudaram a relação do teor de matéria orgânica e a permeabilidade, por meio do ensaio de permeabilidade de parede flexível, obtidos com várias amostras remoldadas e também em amostras tipo Shelby. A Figura 18 ilustra a relação entre o teor de matéria orgânica e o logarítimo da permeabilidade. A relação encontrada pelos autores foi a seguinte:

$$
\mathrm{Oc}=-5,5 \log \mathrm{k}
$$




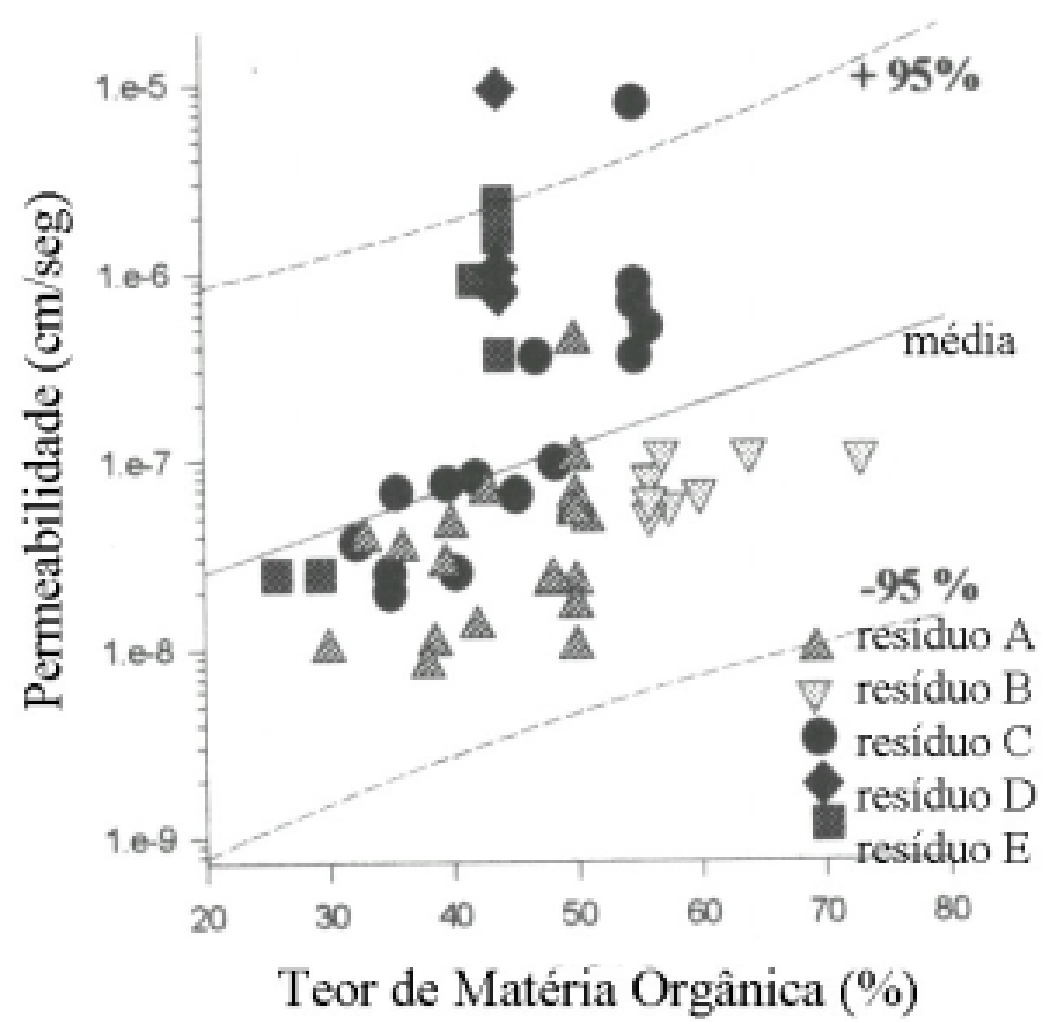

Figura 18 - Teor de matéria orgânica versus permeabilidade (Moo-Young e Zimmie, 1996).

Para avaliar o efeito da decomposição da matéria orgânica na permeabilidade, foram preparadas três amostras com as seguintes características: amostra C1 (1mês), amostra C2 (2-4 anos) e amostra C3 (10-14anos). Cada uma das amostras foi remoldada com teor umidade de $250 \%$. A permeabilidade das amostras foram obtidas para um tensão efetiva de $34,5 \mathrm{kPa}$. Observou-se que a permeabilidade diminui com o decréscimo do teor de matéria orgânica, ou seja, com a idade da amostra. A redução na permeabilidade pode ser atribuída ao incremento da porcentagem de argila caolinita na matriz da amostra ou à decomposição da matéria orgânica com o tempo (LaPlante,1993, apud Moo-Young 1995). A amostra envelhecida C3 apresenta maior teor de argila na composição que as amostras C1 e C2. 


\subsection{Considerações gerais para projeto de aterro utilizando o resíduo de papel.}

Para Quiroz e Zimmie (1998), o primeiro passo importante para o projeto de cobertura de aterro utilizando resíduo de papel é determinar os valores da densidade seca e o teor de umidade a serem utilizados na compactação. Estas caracterizações são importantes para obter-se a permeabilidade e uma resistência ao cisalhamento adequado, pois estes são os critérios para assegurar a perfeita integridade da cobertura do aterro.

Na Figura 19 apresenta-se uma seção transversal típica para cobertura de aterro utilizando resíduo de papel. A espessura típica para a camada de resíduo varia entre $0,75 \mathrm{~m}$ a $1,00 \mathrm{~m}$ dependendo do recalque esperado. As

deformações que ocorrem nas coberturas feitas com argila são abaixo de 2 a $3 \%$ da sua espessura, enquanto que para cobertura de papel os valores podem alcançar 20 a 35\% (Zimmie et al 1993, 1997, apud Quiroz e Zimmie, 1998).

Uma importante consideração mencionada por Quiroz e Zimmie (1998) é a instalação de uma camada drenante acima e abaixo da camada de resíduo para promover o adensamento. Não é recomendável a colocação de geomembrana acima da camada de resíduo, pois este diminui a velocidade do adensamento e evita a migração de alguns gases gerados pelo próprio resíduo de papel, com isso pode provocar a diminuição do valor da tensão efetiva facilitando uma ruptura. 


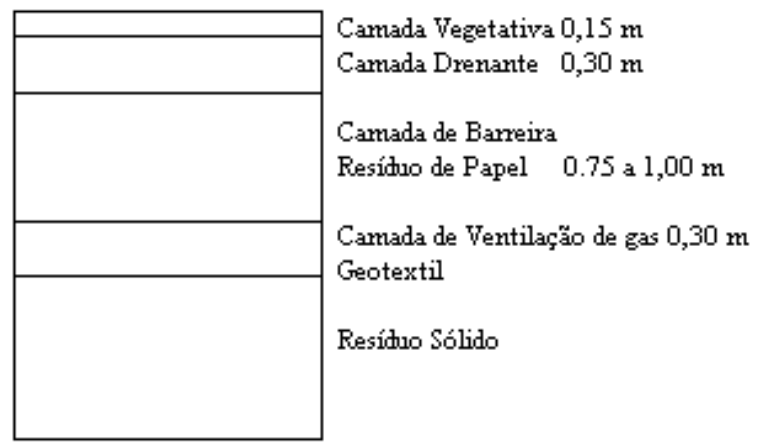

Figura 19 - Perfil típico de um aterro utilizando resíduo de papel.

A interface entre a geomembrana e a camada de resíduo é um ponto crítico. $\mathrm{O}$ atrito desta interface pode alcançar valores críticos (cria-se uma interface lisa) devido ao alto teor de umidade do resíduo de papel. Em sistemas sem o uso do resíduo de papel, o geotextil é colocado entre a base da camada impermeabilizante e no topo da camada de ventilação de gases. Esta camada de geotextil pode ser omitida quando executada com uma camada de barreira de resíduo de papel.

O resíduo de papel pode ser colocado diretamente sobre o solo arenoso sem ocorrer o entupimento da camada ou que ocorra mistura entre ambos (Quiroz e Zimmie, 1998).

Outro aspecto importante no projeto de cobertura para aterro utilizando resíduo de papel é a estabilidade do talude. A baixa resistência ao cisalhamento do resíduo de papel, pode torna-se um fator importante para a integridade geral da cobertura do aterro.

Quiroz et al. (1998) apresentaram resultados de ensaios de palheta, in situ, realizados em uma cobertura de aterro que utilizou o resíduo de papel da fábrica Erving Papel Mill, estudados por Moo-Young e Zimmie (1996). Na Figura 20 são apresentados os resultados da resistência ao cisalhamento não drenada em função do teor de umidade do resíduo. Embora exista uma 
grande variabilidade dos resultados, observa-se a esperada tendência de redução da resistência com o aumento do teor de umidade.

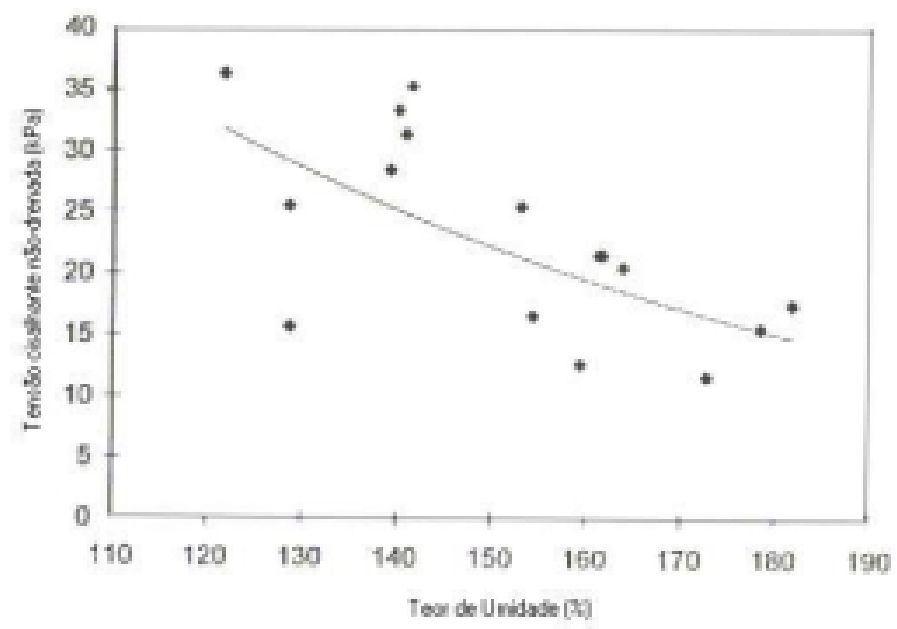

Figura 20 - Resultados do ensaio de palheta apresentados por Quiroz et al.(1998).

De acordo com Sharma and Lewis (1994) (apud Quiroz e Zimmie, 1998) um fator de segurança de cerca de 1,5 é razoável para o projeto. Na análise da estabilidade considera-se a hipótese de talude infinito, desde que a possibilidade da falha mecânica seja plana. A regra prática para resíduo de papel em relação à estabilidade da cobertura é talude lateral de $1(\mathrm{~V}): 4(\mathrm{H})$ de inclinação, que é menor que as das típicas coberturas de argila onde a inclinação do talude é de $1(\mathrm{~V}): 3(\mathrm{H})$.

Cabral et al. (1996), apresentaram dados sobre 3 aterros onde foram utilizados resíduos de papel (Eustis, Clinton, Mirion) onde o perfil típico da cobertura destes aterros é mostrado na Figura 21.

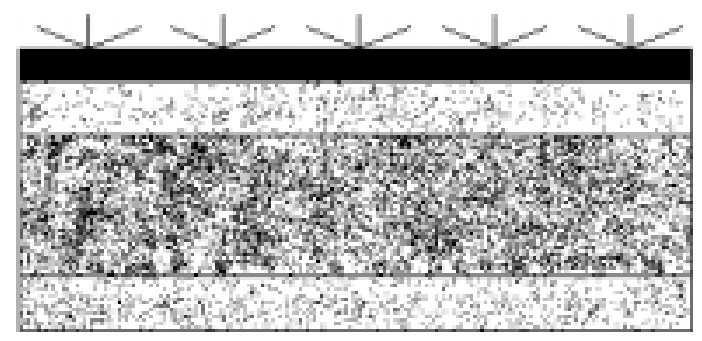

Camada Vegetativa $(15 \mathrm{~cm})$

Camada Granular $(30 \mathrm{~cm})$ Camada de Resíduo Papel $(150 \mathrm{~cm})$

Camada Granular $(30 \mathrm{~cm})$

Figura 21 - Típico perfil utilizando resíduo de papel estudado por Cabral. 
No aterro de Clinton usou-se o resíduo estudado por Cabral et al. (1998) (KF98, PC98) com características descritas na Tabela 3 e 4. A compactação do resíduo foi feita em três camadas de aproximadamente 0,4 $\mathrm{m}$ de espessura de resíduo, finalizando um total de aproximadamente 1,2 $\mathrm{m}$ de espessura de resíduo. Cada camada foi espalhada com a escavadeira de esteira e compactada em três passagens do trator de roda (Figura 22).

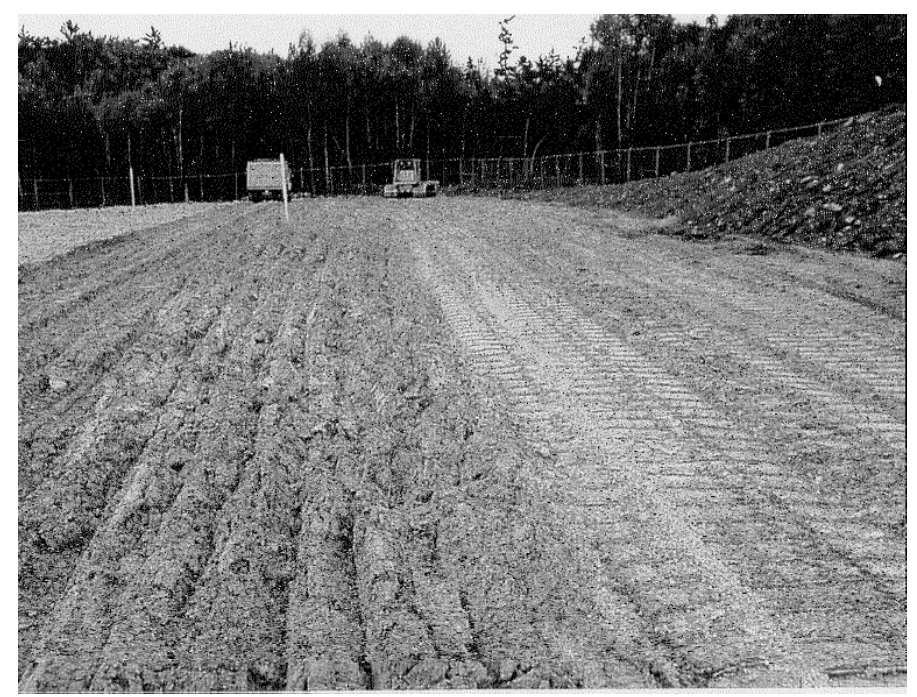

Figura 22 - Construção do aterro de Clinton utilizando resíduo estudado por Cabral et al. (1996).

Cabral et al. (1998), forneceram informações sobre a determinação da densidade obtida no aterro de Clinton. Ensaios utilizando o método do cone de areia realizado durante a compactação, mostraram que o grau de compactação foi menor que o obtido pelo proctor normal. Na Figura 23 são apresentadas as curvas de compactação do resíduo utilizado e, os valores obtidos no campo em um trecho experimental (pontos $A, B$, e C).

No laboratório, a condutividade hidráulica foi de aproximadamente 2,0 x 10 ${ }^{-7}$ $\mathrm{cm} / \mathrm{seg}$ e em campo a mesma variou entre 1 a $5 \times 10^{-6} \mathrm{~cm} / \mathrm{seg}$. Segundo Cabral et al. (1998) as diferenças obtidas entre campo e laboratório estão associadas ao método de ensaio, e suas interpretações, além das diferenças entre as amostras de campo e laboratório. 


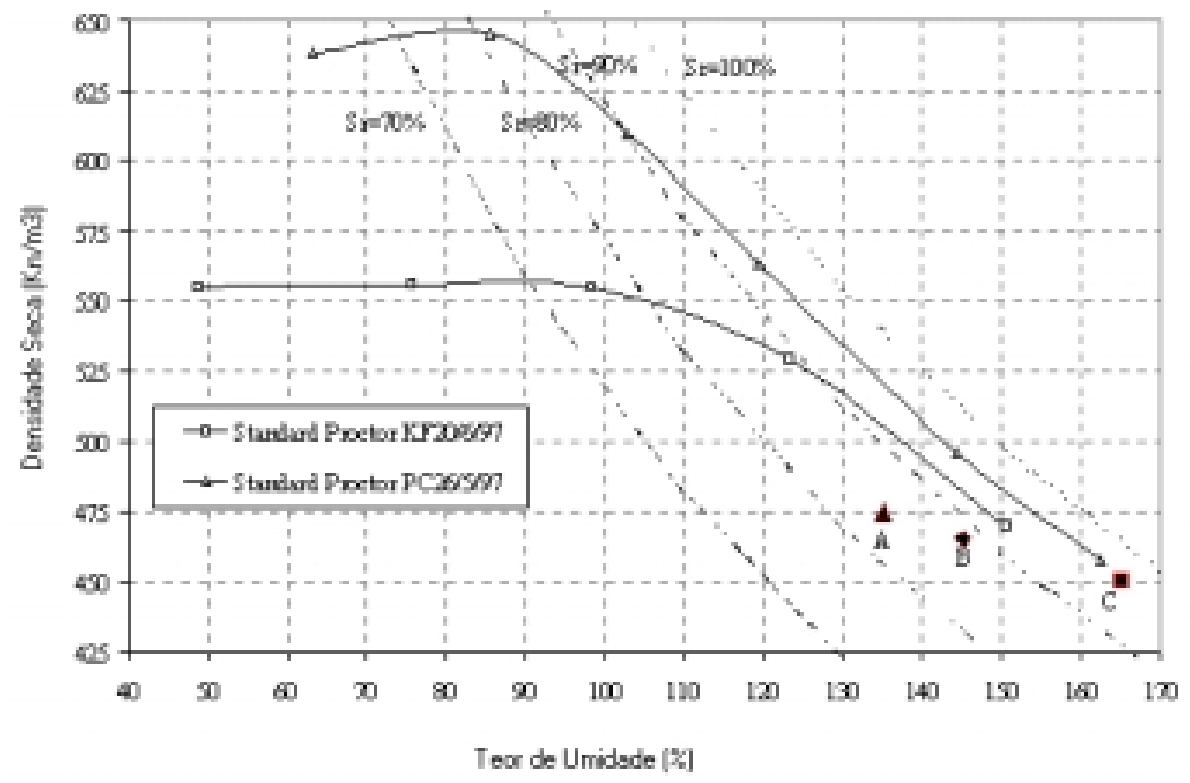

Figura 23 - Curva de compactação do resíduo estudado por Cabral et al. (1996). 


\section{Metodologia de Ensaio}

Para determinar os parâmetros geotécnicos do resíduo da Rigesa serão executados ensaios de caracterização, ensaios de adensamento, cisalhamento direto, placa de sucção e placa de pressão. Estes ensaios foram executados conforme as normas e quando necessário, foram feitas adaptações devido às características do material, obtendo-se assim as seguintes características do resíduo: curva granulométrica, massa específica, curva de compactação, parâmetros de compressibilidade, resistência ao cisalhamento e curva de retenção, parâmetros hidráulicos e ponto de entrada de ar.

$\mathrm{Na}$ Tabela 12 apresenta-se a relação de normas utilizadas para os respectivos ensaios, bem como observações de alterações quando assim houver.

\begin{tabular}{|c|c|c|}
\hline Norma & Nome & Observações \\
\hline NBR 6457/1986 & Determinação do teor de umidade. & \\
\hline NBR 13600 & Determinação do teor de Orgânico. & \\
\hline ABNT,MB-32, NBR 7181 & Solo-Análise Granulométrica & Modificado \\
\hline ABNT, MB -28, NBR 6508 & $\begin{array}{l}\text { Grãos de solos que passam na } \\
\text { peneira de } 4,8 \mathrm{~mm} \text { - Determinação } \\
\text { da Massa Específica. }\end{array}$ & Modificado \\
\hline ABNT, MB - 30, NBR 6459 & $\begin{array}{l}\text { Solo - Determinação do Limite de } \\
\text { Liquidez }\end{array}$ & \\
\hline Britanica BS1377: parte 2:1990 & $\begin{array}{l}\text { Solo- Determinação do Limite de } \\
\text { Liquidez Método do Cone. }\end{array}$ & \\
\hline ABNT, MB -31, NBR7180 & $\begin{array}{l}\text { Solo - Determinação do Limite de } \\
\text { Plasticidade }\end{array}$ & \\
\hline ABNT, MB -33, NBR 7182 & Solo - Ensaio de Compactação & Modificado \\
\hline ABNT 2:04.16-001/1990 & $\begin{array}{l}\text { Solo - Ensaio de Adensamento } \\
\text { Unidimensional }\end{array}$ & \\
\hline
\end{tabular}

Tabela 12 - Resumo das normas utilizadas para o resíduo da Rigesa.

\subsection{Características Geotécnicas}

A classificação geotécnica para resíduo de papel não é a mesma que é utilizada para argilas usadas em sistemas de cobertura de aterro. No 
entanto, o resíduo de papel tem comportamento similar às argilas (MooYoung and Zimmi 1996). Por exemplo, o Ensaio de Limites de Atterberg é de difícil execução, devido ao alto teor de umidade inicial do resíduo de papel e a presença de fibras. Os resultados não podem ser manipulados em termos de classificação geotécnica (apud. LaPlante;1993). Na literatura a grande maioria dos autores mencionam que a determinação do teor de matéria orgânica, densidade relativa dos grãos, teor de umidade natural e compressibilidade são as propriedades físicas mais importantes para a caracterização do resíduo de papel. Deve-se, no entanto incluir também a curva de retenção e as características de resistência.

Durante a estocagem do resíduo da Rigesa no laboratório observou-se o aparecimento de fungo na superfície do resíduo em poucos meses de estocagem.

A avaliação físico-química do resíduo da Rigesa foi executada pelo setor de Química da ESALQ/USP. O resíduo da Rigesa é proveniente do tratamento dos efluentes da estação de reciclagem do papel. As determinações foram feitas de acordo com a metodologia usual para análise de resíduos orgânicos utilizados no setor de Química Ambiental da ESALQ/USP. Através desta análise concluímos que eventuais variações na sua composição será função do processo utilizado na indústria.

Para esta avaliação, diariamente foram coletadas amostras de lodo recémproduzido. Essas amostras diárias foram armazenadas em refrigerador e após uma semana foram misturadas para formar uma amostra composta correspondente àquelas semanas. Dessa forma, num período de 9 semanas, 9 amostras compostas foram obtidas, correspondentes a esse período de trabalho da indústria.

Também foram analisadas quatro amostras compostas formadas por três amostras simples do lodo armazenado em valas pela indústria para 
verificação de possíveis alterações na sua composição devidas a esse armazenamento.

A caracterização do lodo fresco apresenta o resíduo como sendo um material orgânico, que é composto principalmente por fibras com elevado teor de umidade e baixa acidez. Dentre os seus constituintes se destaca o nitrogênio, como sendo o de maior concentração. Os metais pesados $(\mathrm{Cd}$, $\mathrm{Cr}, \mathrm{CU}, \mathrm{Mn}, \mathrm{Ni}$, e $\mathrm{Zn}$ ) analisados estiveram em níveis muito baixos, inclusive desestimulando qualquer estudo de biodisponibilidade desses elementos. Para o lodo armazenado em valas, a variação na composição foi maior, porém essa variação foi devida ao teor de água da amostra. A Figura 24 apresenta o resíduo durante o processo de secagem ao ar.
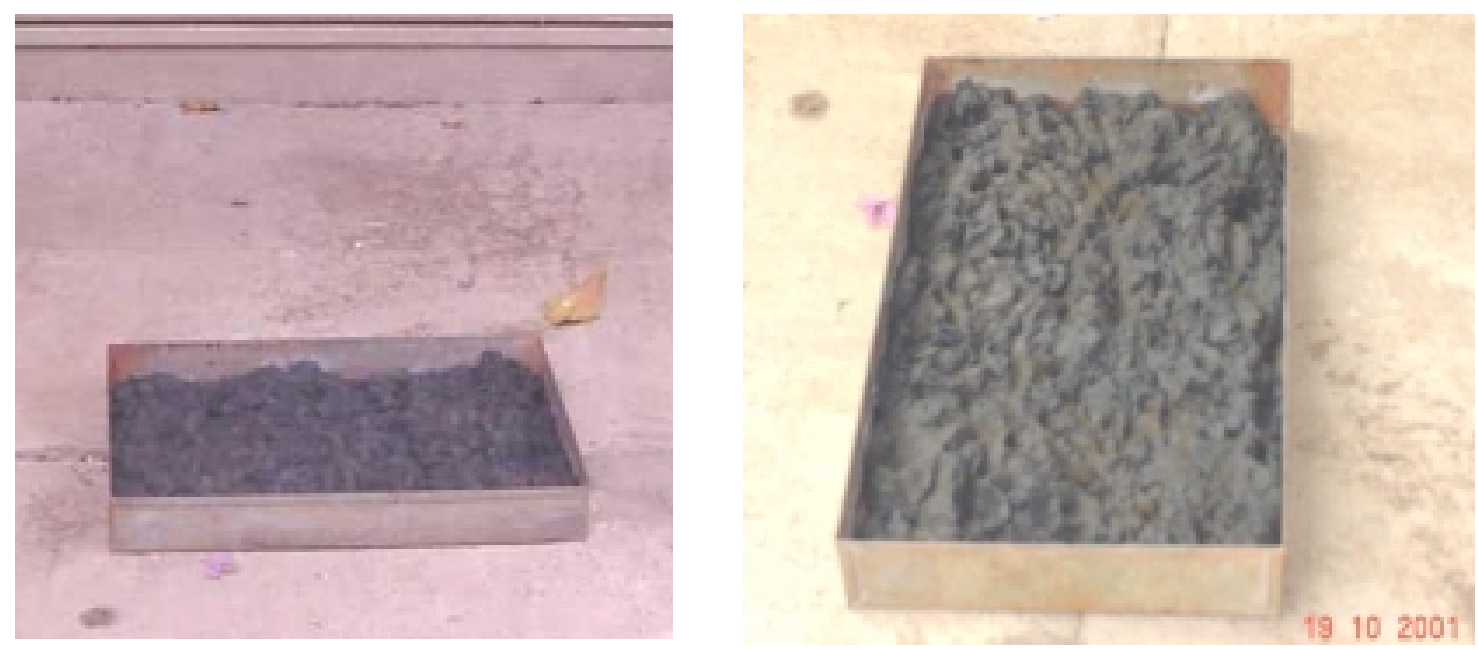

Figura 24 - Resíduo de papel da Rigesa secando ao ar.

\subsection{Determinação do Teor de Umidade e Teor de Matéria Orgânica}

Para a determinação do teor de umidade foi utilizada inicialmente uma estufa com temperatura entre $105^{\circ} \mathrm{C}$ e $110^{\circ} \mathrm{C}$, depois se optou em utilizar a estufa com temperatura de $60^{\circ} \mathrm{C}$. Com isso houve uma variação no teor de 
umidade que ocorre devido à queima de matéria orgânica quando se utiliza a estufa com temperatura de $105^{\circ} \mathrm{C}$. Para a determinação do teor de matéria orgânica foi utilizado mufla à temperatura de $600^{\circ}$ para a queima total da matéria orgânica.

Para verificar a influência da temperatura na perda de peso do resíduo da Rigesa, o material foi ensaiado variando-se a temperatura da estufa. Utilizaram-se as seguintes temperaturas: 60, 70, $105^{\circ} 400^{\circ}, 450^{\circ}$ e $600^{\circ} \mathrm{C}$. A Figura 25 apresenta a redução de peso da amostra com a variação da temperatura da estufa.

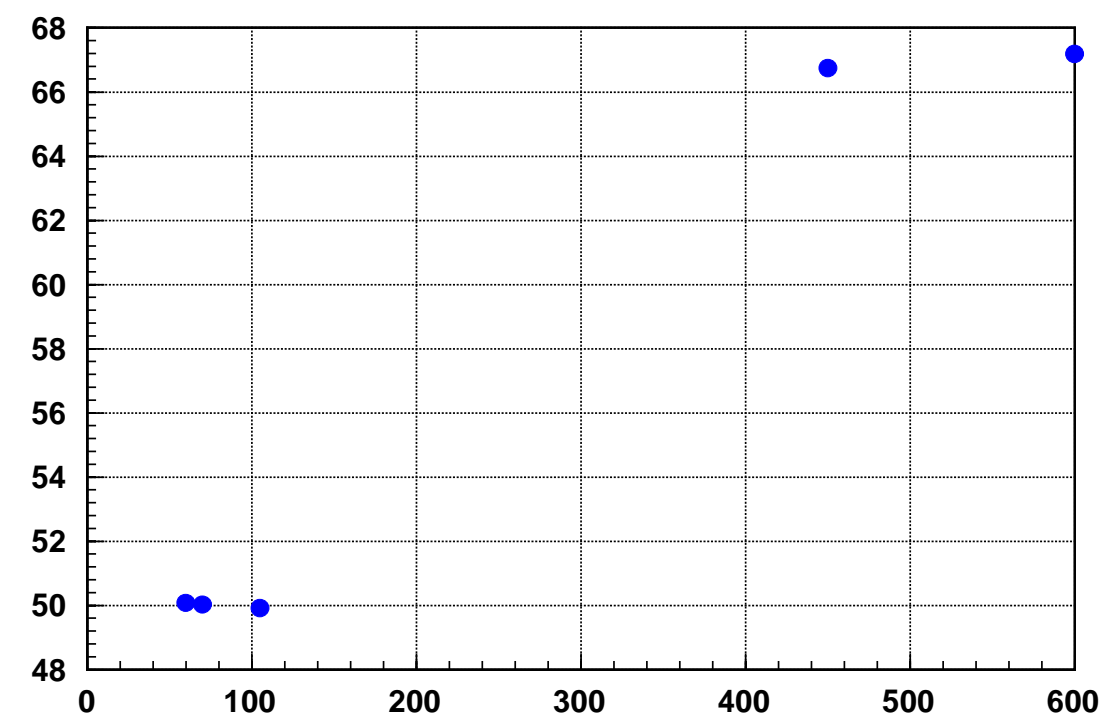

Amostra

- Rigesa

Figura 25 - Redução de peso e temperatura da estufa.

\subsection{Ensaio de Massa Específica dos Sólidos}

A massa específica dos sólidos, de um solo ou material poroso, é função dos materiais sólidos constituintes e da porcentagem de ocorrência de cada um deles no material. 
Após a homogeneização da amostra foram retiradas três porções de resíduo para a determinação do teor de umidade, e cerca de $60 \mathrm{~g}$ de amostra úmida, para a determinação da massa específica dos sólidos. Em seguida determinou-se a massa dessa porção de resíduo colocando-a em uma cápsula, acrescentando-se água destilada necessária à formação de uma pasta homogênea. A água destilada foi acrescentada até a completa imersão da pasta, que ficou em repouso por 12 horas.

Após o repouso transferiu-se o conteúdo da cápsula para o copo do dispersor, tomando-se o cuidado para que não perdessem partículas, e adicionou-se mais água destilada para diminuir a concentração e deixou-se no dispersor durante 15 minutos.

Com o auxílio de um funil, transferiu-se a suspensão para o picnômetro, tomando o cuidado para que não restassem partículas no copo, no funil e nem na parte interna da haste. O volume da suspensão, neste instante, não deverá ser maior do que a metade do volume útil do picnômetro.

O ar existente na suspensão foi retirado com ajuda de uma bomba de vácuo $(710 \mathrm{mmHg})$ durante aproximadamente 2 horas até quando se percebeu que não mais apareciam bolhas de ar à superfície da suspensão. Este tempo elevado foi provavelmente devido à natureza fibrosa e sua "granulométria" fina que dificulta a saída de ar da amostra. A norma orienta deixar no mínimo 30 minutos na bomba de vácuo para solos argiloso, ou até que não mais apareçam bolhas de ar na suspensão.

Colocou-se mais água destilada no picnômetro, até um centímetro abaixo da marca de referência na haste, de forma cuidadosa, evitando-se a movimentação da água existente e aplicou-se novamente vácuo até a completa retirada de ar da suspensão.

Após a completa retirada de ar da suspensão adicionou-se água destilada cuidadosamente até que a base do menisco tangencia-se a marca de 
referência na haste. Colocou-se a suspensão em repouso em ambiente fechado para homogeneização da temperatura. Após este fato, enxugou-se a parte interna do picnômetro, acima da marca de referência, e a superfície externa do picnômetro e assim foi determinada a massa do conjunto (picnômetro + sólido + água). Após a pesagem determinou-se a temperatura do conjunto. A suspensão foi recolhida em um recipiente de evaporação e levada a uma estufa para secagem, que estava ajustada para uma temperatura de $60^{\circ} \mathrm{C}$. A amostra seca foi pesada para a determinação da massa de sólido. Foram executados dois ensaios seguindo o procedimento acima descrito e calculou-se a média. Os valores encontrados não se afastaram da média mais do que $0,020 \mathrm{~g} / \mathrm{cm}^{3}$. A norma recomenda considerar os ensaios satisfatórios quando os resultados não diferirem de mais que $0,02 \mathrm{~g} / \mathrm{cm}^{3}$. O resultado final é a média obtida de pelo menos dois ensaios considerados satisfatórios.

Para o resíduo da Rigesa obteve-se uma densidade dos grãos de 1,62 $\mathrm{g} / \mathrm{cm}^{3}$.

\subsection{Ensaio de Granulometria}

Para o ensaio de Granulometria foram realizados cinco procedimentos objetivando avaliar o comportamento do resíduo. Na tabela 13 abaixo são apresentados os procedimentos utilizados no ensaio.

\begin{tabular}{|c|c|c|c|}
\hline Procedimento & $\begin{array}{c}\text { Característica inicial } \\
\text { da amostra }\end{array}$ & Defloculante & $\begin{array}{c}\text { Tempo de repouso da } \\
\text { suspensão }\end{array}$ \\
\hline 1 & Sem secagem prévia & Com & 12 horas \\
\hline 2 & Sem secagem prévia & Sem & 12 horas \\
\hline 3 & Com secagem prévia & Com & 12 horas \\
\hline 4 & Sem secagem prévia & Com & 24 horas \\
\hline 5 & Sem secagem prévia & Sem & 24 horas \\
\hline
\end{tabular}

Tabela 13 - Procedimentos de ensaio para o ensaio de gramulometria. 


\subsubsection{Procedimento 1}

Explicaremos inicialmente o ensaio no qual utilizou-se a amostra sem secagem prévia. Todo o resíduo passa pela peneira $n^{\circ} 10$. Para a sedimentação foram utilizadas cerca de $60 \mathrm{~g}$ de material úmido o que corresponde a $20 \mathrm{~g}$ de material seco devido ao alto teor de umidade do mesmo. Sendo que a norma recomenda cerca de $70 \mathrm{~g}$ de material seco ao ar, no caso de solos siltosos e argilosos. O material foi colocado num recipiente com $125 \mathrm{~cm}^{3}$ de defloculante (hexametafosfato de sódio) e foi deixado de repouso por cerca de 12 horas, após este tempo foi colocada a mistura no copo de dispersão, removendo-se com água destilada, com auxílio da bisnaga, o material aderido ao recipiente. Adicionou-se água destilada e submeteu-se a amostra a ação do aparelho dispersor durante 15 minutos.

Transferiu-se o material para a proveta e removeu-se com água destilada, com auxílio da bisnaga, todo o material aderido ao copo. Juntou-se água destilada até atingir o traço correspondente a $1.000 \mathrm{~cm}^{3}$; em seguida foi deixado em repouso em ambiente fechado para a estabilização da temperatura por 12 horas. Logo após este tempo tomou-se a proveta e tampando a sua boca com a outra mão, foram feitos, com auxílio da outra, movimentos enérgicos de rotação, durante 1 minuto, pelos quais a boca da proveta passava de cima para baixo e vice-versa. Imediatamente após a agitação, colocou-se a proveta sobre a bancada, efetuando as leituras do densímetro correspondente aos tempos de sedimentação $(\mathrm{t})$ de 0,5, 1 e 2 minutos. Retirou-se lenta e cuidadosamente o densímetro da dispersão. Fazemos as leituras subseqüentes com 4, 8, 15 e 30 minutos , 1, 2, 4, 8 e 24 horas a contar do início da sedimentação. Após cada leitura foi medida a temperatura. Terminada a última leitura, verteu-se todo o material da proveta na peneira de $0,075 \mathrm{~mm}$ (peneira $\mathrm{n}^{0} 200$ ) e efetuou-se a lavagem do material na peneira mencionada, utilizando água com baixa pressão. Após a lavagem, colocou-se o material retido na peneira de $0,075 \mathrm{~mm}$ numa cápsula de porcelana que foi secado em estufa a $60^{\circ} \mathrm{C}$. Depois da secagem do 
material deveria se fazer o peneiramento fino, mas isso não foi possível, pois o material após essa secagem ficou fixado na cápsula de porcelana, formando uma película em sua parede.

\subsection{Procedimento 2}

No segundo procedimento utilizado optou-se pela não utilização do defloculante, para avaliar o seu efeito no ensaio com o resíduo.

Pesou-se cerca de $60 \mathrm{~g}$ de resíduo sem secagem prévia e que foram colocados em um recipiente onde se acrescentou água destilada. O material foi deixado em repouso por 12 horas.

Seguiu-se a mesma rotina apresentada para o procedimento 1. O material retido na peneira 200 foi colocado em estufa para ser utilizado no peneiramento fino. No entanto, não foi possível a execução do peneiramento fino, pois o material após a secagem ficou fixado na cápsula de porcelana, formando uma película em sua parede da mesma forma que no procedimento anterior.

\subsubsection{Procedimento 3}

Para o terceiro procedimento, utilizou-se o resíduo com secagem prévia e defloculante. Como o resíduo, após a secagem, forma torrões foi necessário que os mesmos fossem peneirados na peneira $\mathrm{n} \times 10$. Com o material passado pela peneira foi executada a sedimentação.

Para a sedimentação foram utilizados cerca de $60 \mathrm{~g}$ de resíduo, o mesmo foi colocado num recipiente com $125 \mathrm{~cm}^{3}$ de defloculante (hexametafosfato de sódio) e foi deixado de repouso por cerca de 12 horas. Após seguir toda a rotina mencionada nos procedimentos anteriores, a amostra retida na peneira 200 foi seca em estufa (a $60^{\circ} \mathrm{C}$ ). Mais uma vez observou-se a 
formação de uma película que impossibilitou a execução do peneiramento fino.

\subsubsection{Procedimentos 4 e 5}

Os procedimentos 4 e 5 só diferem dos procedimentos 1 e 2 respectivamente, em relação ao tempo de repouso da suspensão que passou de 12 para 24 horas.

\subsubsection{Resultados obtidos}

Durante a execução dos ensaios pudemos notar certas dificuldades tais como surgimento de uma espessa espuma que impediu uma leitura confiável principalmente nas primeiras leituras. Quando se utilizou amostra com secagem prévia, o resíduo não se hidratou imediatamente, ficando flutuando acima do defloculante. Durante a sedimentação ocorreu uma inversão na queda dos "grãos", as partículas, ao invés de causar sedimentação sobem. As dificuldades encontradas na execução dos ensaios podem ser devido ao material ser muito fibroso e quando seco forma torrões e perde sua plasticidade inicial.

$\mathrm{Na}$ Figura 26 observam-se três provetas durante um ensaio de sedimentação. Nas duas externas foi utilizado defloculante e na do meio apenas água destilada. O tempo de sedimentação do material sem defloculante foi significativamente menor, podendo-se observar a água límpida na parte superior da proveta. 


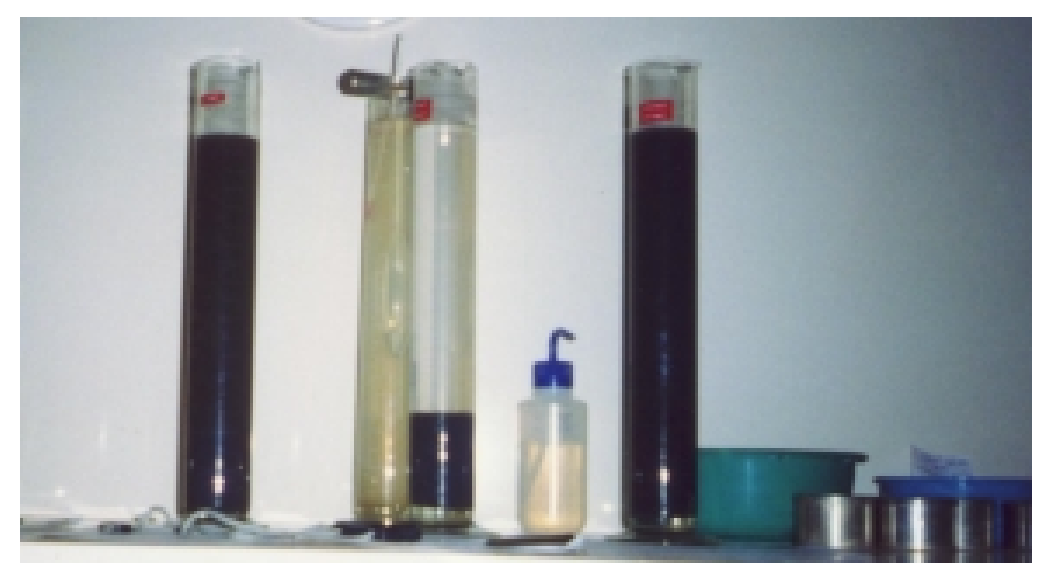

Figura 26 - Ensaio de sedimentação do resíduo da Rigesa.

Para uma melhor visualização das diferenças nos procedimentos são apresentados a seguir os resultados obtidos. Salienta-se antecipadamente que a interpretação das curvas obtidas não pode ser feita de forma convencional. Os resultados serão comparados para se avaliar os efeitos dos diferentes procedimentos utilizados.

Nas Figuras 27 e 28 são apresentados os resultados dos ensaios sem secagem prévia da amostra, com e sem uso de defloculante, respectivamente. Observa-se que o uso do defloculante acarreta um aumento aparente, porém significativo dos "finos". Houve uma grande dispersão nos resultados do ensaio sem defloculante.

Comparando-se os resultados da Figura 27 com os da Figura 29 pode-se verificar a influência da secagem prévia. Os resultados sugerem que a secagem induz a uma maior aglutinação das partículas (ou fibras). 


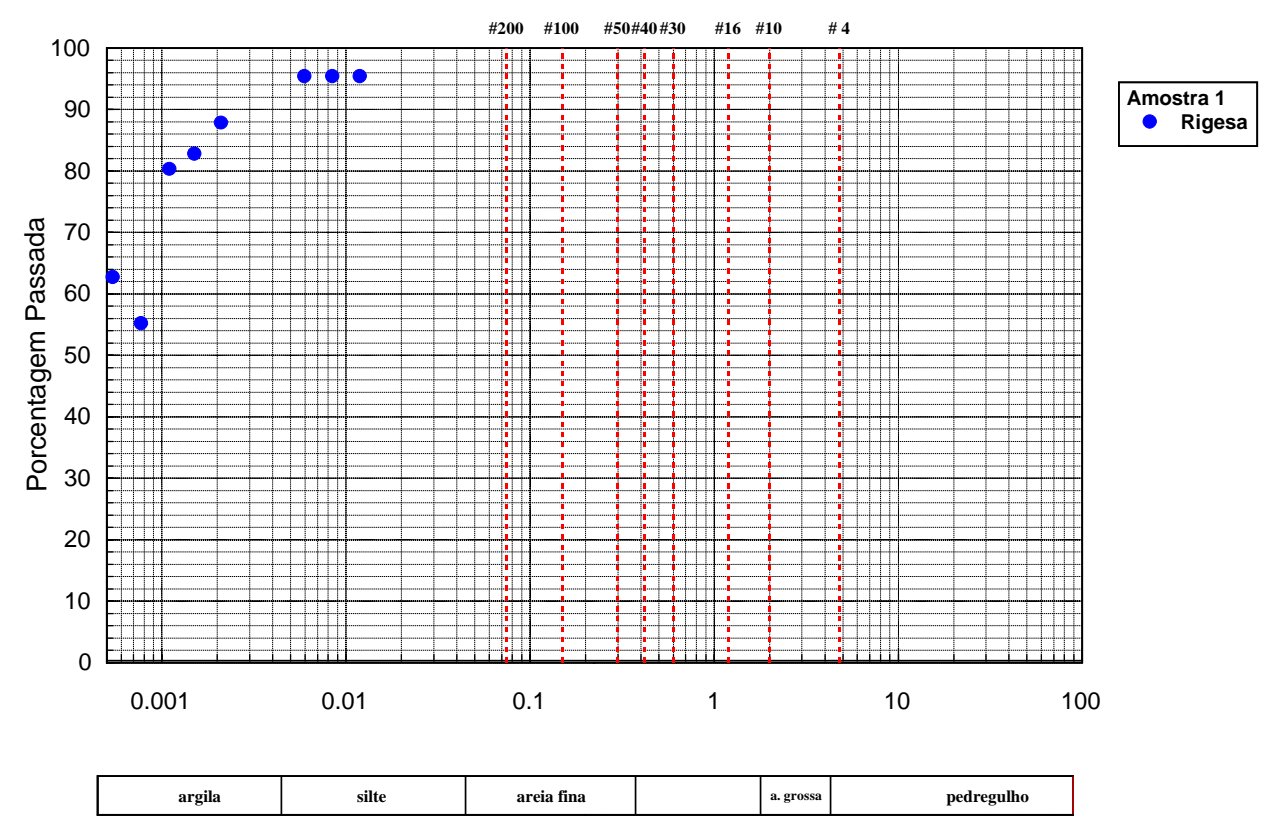

Figura 27- Curva granulométrica sem secagem e com uso de defloculante (Procedimento1)

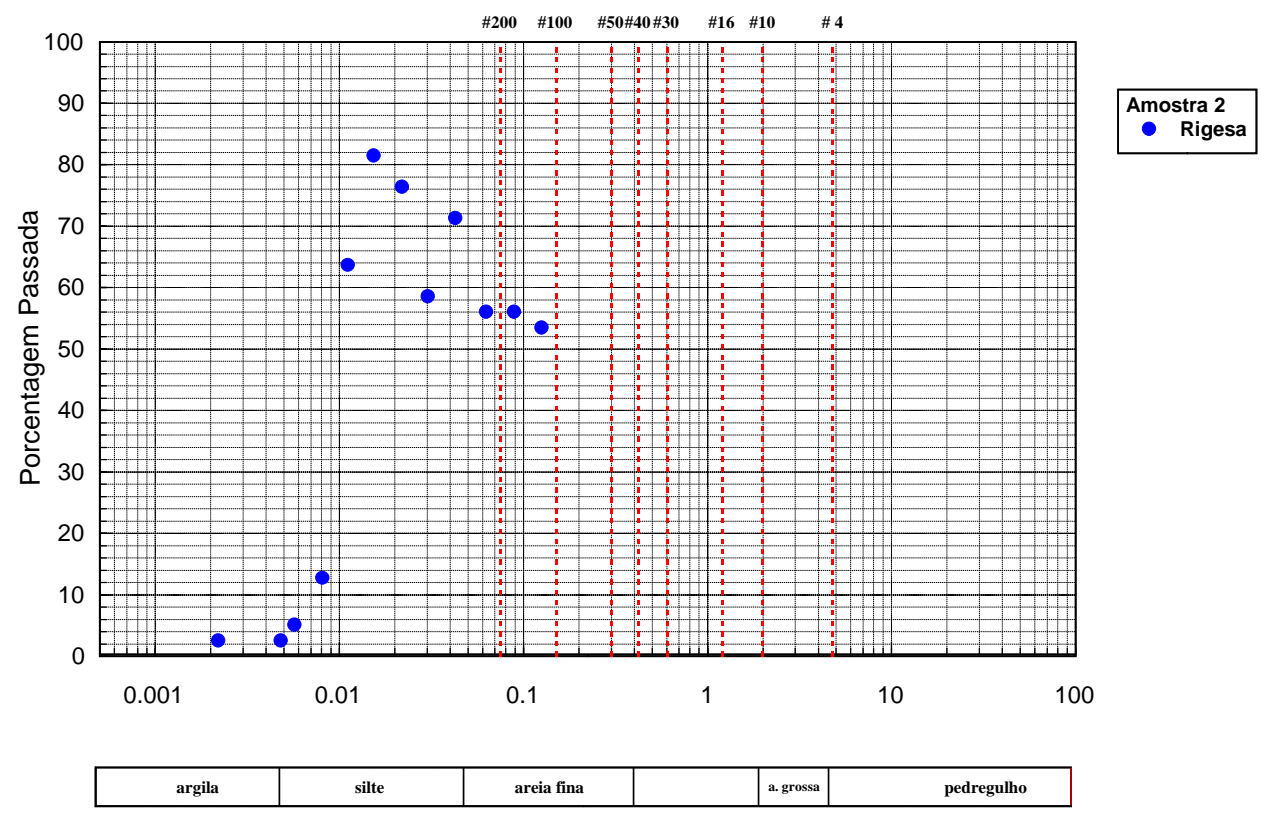

Figura 28 - Curva granulométrica sem secagem e sem uso de defloculante (Procedimento 2) 


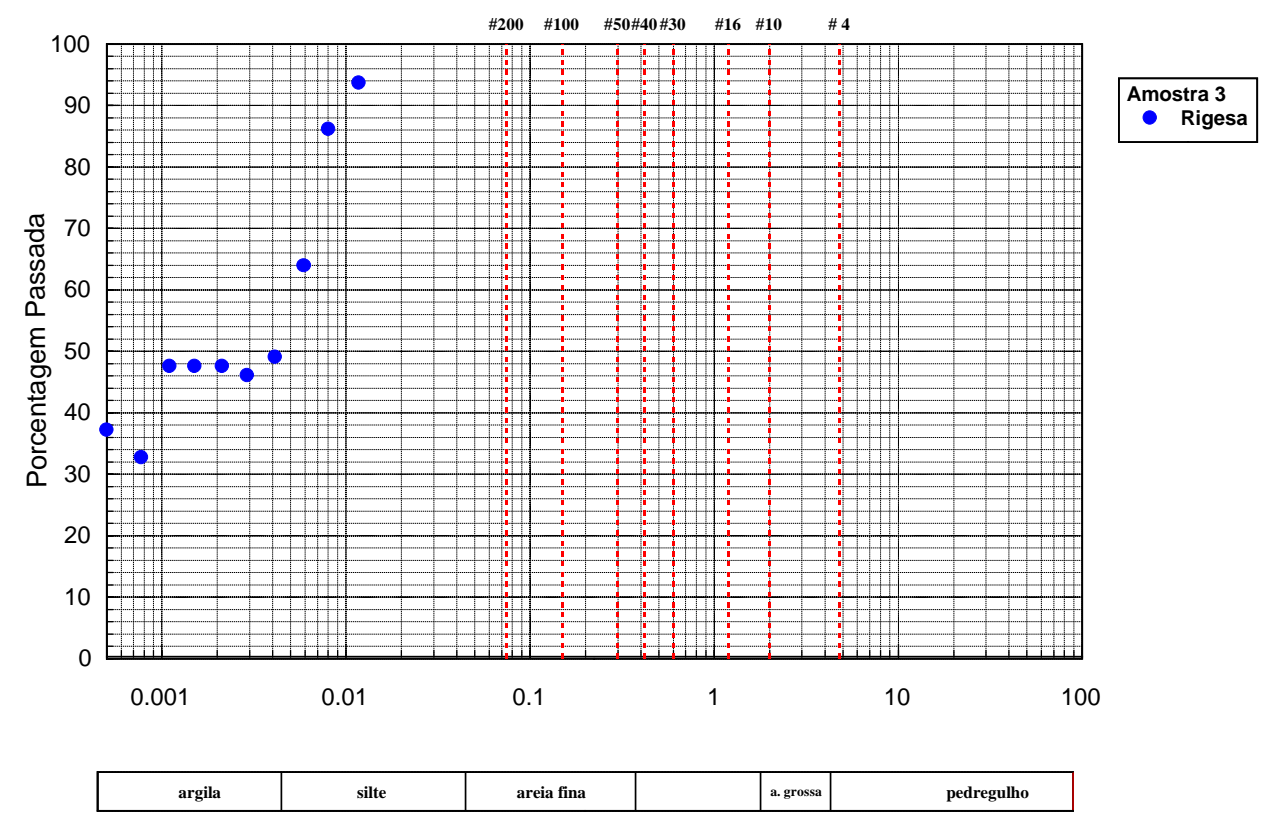

Figura 29- Curva granulométrica com secagem e com uso de defloculante (Procedimento 3).

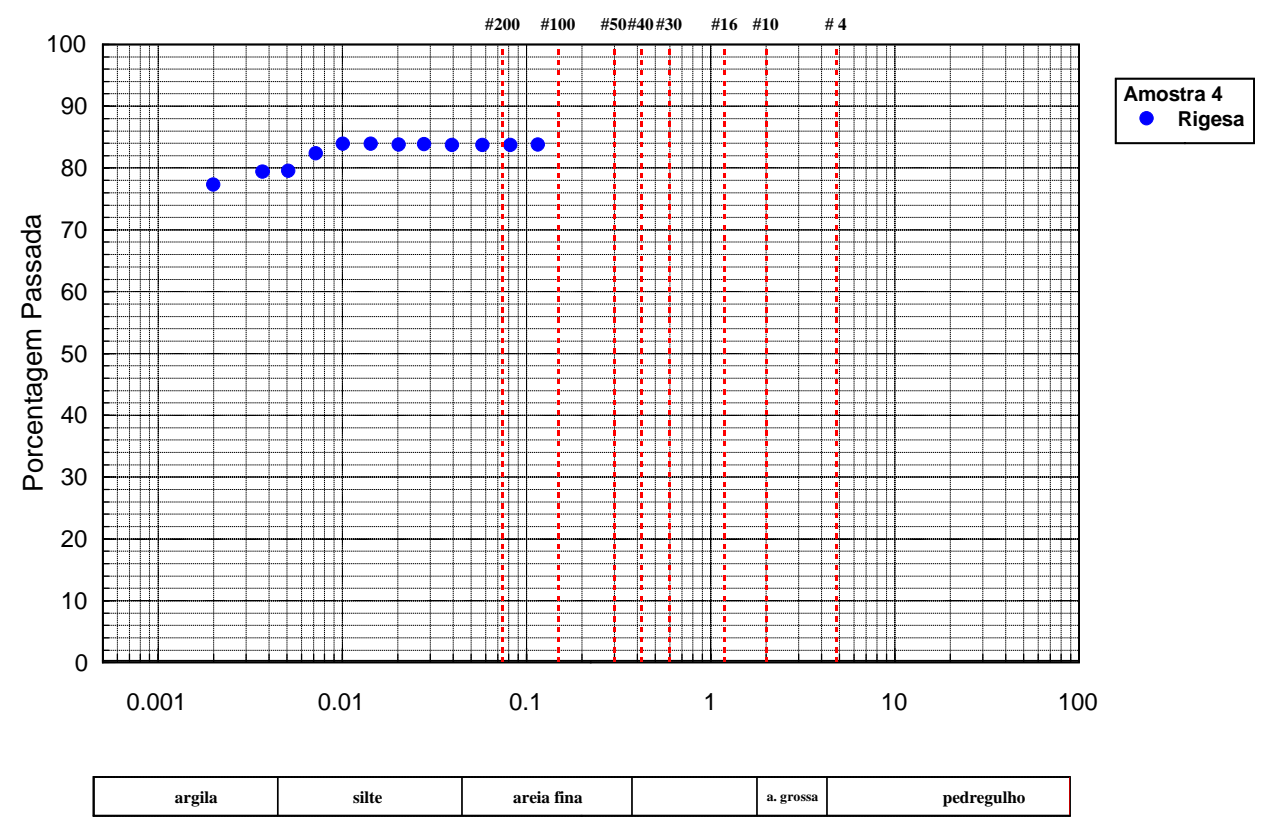

Figura 30- Curva granulométrica do resíduo da Rigesa (Procedimento 4). 
Uma comparação entre os tempos de repouso da suspensão pode ser feita entre os resultados apresentados nas Figuras 27 e 30 . Embora haja uma aparente redução na dispersão, nada se pode concluir sobre o tempo de repouso. A falta do trecho correspondente ao peneiramento fino está ausente em todas as curvas.

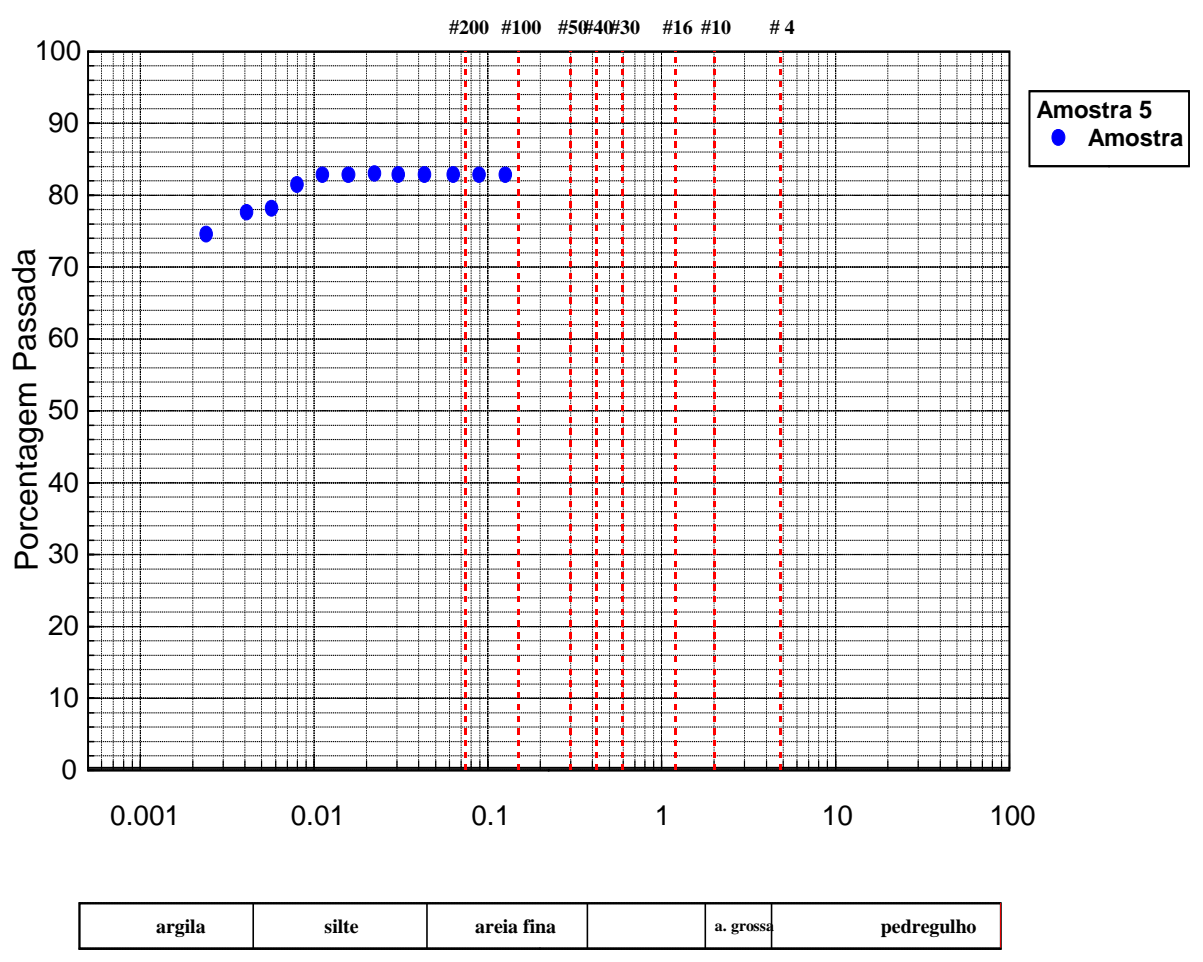

Figura 31 - Curva granulométrica sem secagem e com uso de defloculante (Procedimento 5).

Observa-se, no entanto, que as amostras ensaiadas sem secagem e sem defloculante, para os tempos de repouso de 12 e 24 horas, Figuras 28, e 31, respectivamente, apresentam uma significativa redução na dispersão, de modo a sugerir que o tempo de repouso possa ter uma influência significativa nos resultados quando não se usa secagem prévia nem defloculante. 


\subsection{Ensaio de Limite de Consistência}

Os índices de consistência mostraram-se muito úteis para a identificação dos solos e sua classificação. Desta forma, com o seu conhecimento, podese prever muito do comportamento do solo, sob o ponto de vista da engenharia, com base em experiências anteriores (Pinto, 2000). Salienta-se, no entanto que o significado dos limites para o caso do resíduo de papel não é o mesmo dos solos.

Utilizamos para execução deste ensaio amostras sem secagem prévia, onde após cada ponto obtido a amostra era seca revolvendo-a com uma espátula metálica dentro de um cadinho de porcelana até alcançar o teor de umidade estimado para cada ponto.

\subsubsection{Limite de Liquidez - Aparelho de Casagrande}

Após a perfeita homogeneização da amostra, a mesma foi colocada sobre a concha do aparelho de Casagrande e distribuída de forma uniforme, utilizando uma espátula flexível, resultando uma superfície não muito lisa devido ao alto teor de fibras existente no resíduo. A espessura máxima da camada de resíduo, na concha, não passou de $10 \mathrm{~mm}$ e a largura igual a 2/3 do diâmetro da concha. A distribuição da amostra na concha foi realizada com movimento lento e de baixa pressão tomando-se o cuidado para evitar a presença de bolhas de ar no interior da massa. Com cinzel padronizado abriu-se uma ranhura no resíduo, ao longo de um plano normal ao sistema de fixação de tal forma, que as partes resultantes tenham massas, aproximadamente iguais. Nas operações descritas, a concha do aparelho de Casagrande estava apoiada na palma da mão. Após a preparação desta operação a manivela foi girada, a uma razão de 2 voltas por segundo, e contando o número de golpes necessários para que as bordas inferiores do resíduo se unam ao longo de $13 \mathrm{~mm}$ de comprimento aproximadamente. Do local onde as bordas se uniram retirou-se uma amostra do resíduo para a 
determinação do teor de umidade, assim determina-se um par de valores teor de umidade - número de golpes.

O resíduo restante na concha foi transferido para a cápsula de porcelana e misturado com o que lá está, de forma a homogeneizá-lo, quanto ao teor de umidade. A concha foi então limpa e seca antes da próxima determinação. As operações descritas para a obtenção do primeiro ponto foram repetidas, até que, um mínimo de 5 pares de valores fossem obtidos. Em um papel semi-logarítmico inseriram-se os pontos representativos dos pontos obtidos, e traçou-se, visualmente a reta que melhor se ajusta aos pontos. O limite de liquidez é o teor de umidade correspondente a 25 golpes e o resultado obtido levado ao inteiro mais próximo e dado em porcentagem.

A Figura 32 mostra o gráfico do limite de liquidez obtido para o resíduo da Rigesa. Com estes resultados, o valor do limite de liquidez encontrado para o resíduo da Rigesa foi de $520 \%$.

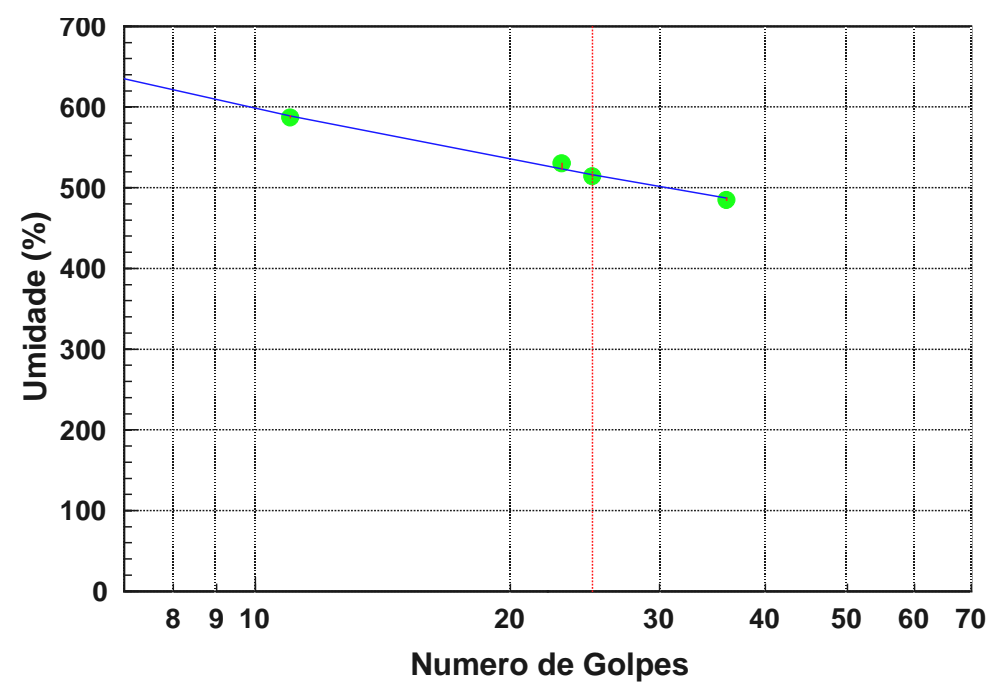

Figura 32 - Gráfico do limite de liquidez do resíduo da Rigesa. 


\subsubsection{Limite de Liquidez - Ensaio de Cone}

Com o objetivo de se comparar os resultados obtidos com o aparelho de Casagrande foi executado o ensaio para determinação do limite de liquidez utilizando-se o cone. A amostra foi preparada da mesma forma que para o ensaio de limite de liquidez determinado por Casagrande. A colocação da pasta de resíduo, previamente preparada, na cápsula deve seguir um procedimento que minimizou a formação de bolhas de ar no meio da amostra. Para isso iniciou-se a colocação de uma fina camada de resíduo sobre a lateral e o fundo e a seguir preencheu-se o centro da cápsula distribuindo a pasta de resíduo de forma uniforme, usando uma espátula flexível até que houve um pequeno excesso de resíduo sobre a cápsula. Com uma régua metálica rígida foi retirado esse excesso de resíduo deixando uma superfície plana e quase lisa, pois, o excesso de fibras não permitiu que a superfície ficasse totalmente lisa. Durante o processo de colocação da pasta de resíduo na cápsula uma leva pressão sobre o resíduo foi exercida.

A cápsula com o resíduo foi colocada na base do penetrômetro e, após, abaixar o cone, com todo o cuidado, até que sua ponta tocou a superfície da amostra. A movimentação da cápsula para os lados fez com que aparecesse uma marca na amostra. Com o cone situado sobre o centro da cápsula foi feita uma leitura no relógio comparador com resolução de $0,1 \mathrm{~mm}\left(\mathrm{R}_{0}\right)$.

Para se realizar o ensaio deve-se, inicialmente, pressionar o sistema que libera a descida do cone deixando-o livre para penetrar na amostra, durante cinco segundos e, em seguida aliviar esse sistema interrompendo a movimentação do cone. Em seguida, faz-se uma leitura $\left(R_{f}\right)$ no relógio comparador e a diferença $R_{0}-R_{f}=R_{1}$ indicará a penetração do cone na amostra. O controle do intervalo de tempo de penetração deve ser realizado com muito rigor evitando-se, também, que o penetrômetro sofra qualquer vibração durante a realização do ensaio. Em seguida, retira-se o cone e fazse uma cuidadosa limpeza da sua superfície. Adiciona-se mais resíduo à 
cápsula deixando o topo da amostra bem plano para se obter um segundo par de leitura, $R_{0}, R_{f}$. Se a diferença entre $R_{1}$ e $R_{2}$ for inferior a $0.5 \mathrm{~mm}$ tomase à média destas duas leituras.

Caso a diferença seja superior a $0,5 \mathrm{~mm}$ mais inferior a $1 \mathrm{~mm}$ deve-se obter um terceiro ponto com o qual se faz a média dos três, sendo que nenhum dos pontos pode diferir mais que $1 \mathrm{~mm}$.

Terminada a medição da penetração deve-se retirar uma amostra do resíduo no local ensaiado para a determinação do teor de umidade $(R-w)$.

O resíduo contido na cápsula foi retirado e juntado ao resíduo excedente da cápsula de porcelana e o teor de umidade, novamente, homogeneizado. Em seguida, juntar uma quantidade de água destilada amostra e proceder a uma homogeneização do teor de umidade.

Após a primeira determinação a cápsula foi limpa e seca internamente e o procedimento anterior para a determinação da penetração foi repetido até a obtenção de no mínimo de 4 pare de valores, penetração do cone - teor de umidade. $O$ intervalo de variação da penetração deverá estar, preferencialmente, entre 15 e $25 \mathrm{~mm}$.

Os pares de valores obtido são colocados em um gráfico, com escala natural, onde na abscissa serão marcados os teores de umidade e na ordenada os respectivos valores das penetrações.

Em seguida, traça-se a reta que melhor se ajusta aos pontos. O limite de liquidez é obtido determinando-se o teor de umidade, levado ao inteiro mais próximo, correspondente a uma penetração de $20 \mathrm{~mm}$. A Figura 33 mostra os valores obtidos no ensaio. 


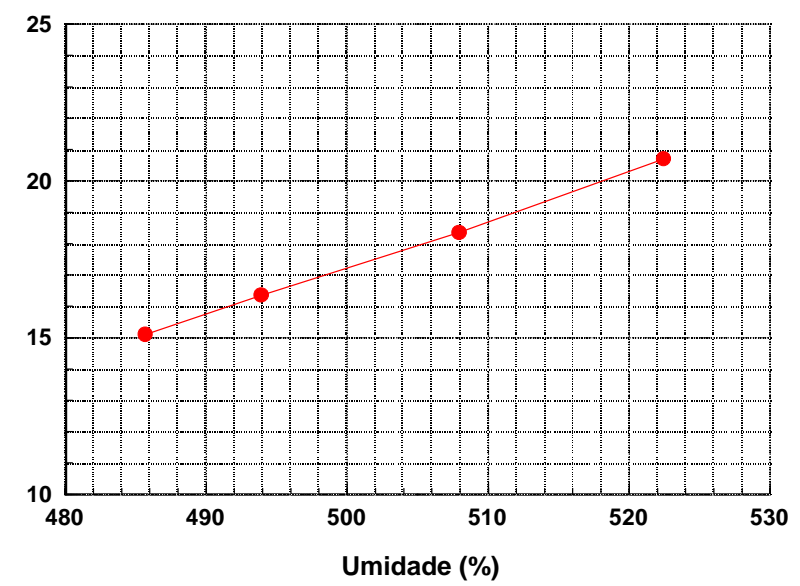

Figura 33 - Gráfico do limite de liquidez pelo método do cone para o resíduo da Rigesa.

Observa-se que os resultados obtidos com os dois procedimentos indicam aproximadamente os mesmos valores de $\mathrm{w}_{\mathrm{l}}$. O limite de liquidez obtido com o ensaio de cone foi de $518 \%$.

\subsubsection{Limite de Plasticidade}

Uma parte da amostra foi transferida para uma cápsula de porcelana e homogeneizada, quanto ao teor de umidade. Com cerca de $10 \mathrm{~g}$ dessa pasta de resíduo fez-se uma bola e, em seguida, colocou-se sobre a fase esmerilhada da placa de vidro e com a palma da mão iniciou-se a rolagem da amostra até transformá-la em um cilindro, evitando aplicar uma pressão que possa amassar o cilindro de resíduo em vez de rolá-lo. Nesse período o operador deverá estar atento ao que poderá estar acontecendo na superfície do rolinho.

Quando as duas condições, rolinho com diâmetro $3 \mathrm{~mm}$ (comparar com o gabarito) e o aparecimento de fissuras na superfície, forem obtidos, simultaneamente, parar o ensaio e determinar o teor de umidade das partes dos rolinhos que estão fissuradas. Se houver alguma sobra de resíduo, juntar à amostra contida na cápsula de porcelana e homogeneizar o seu teor 
de umidade e repetir as operações descritas até a obtenção de cinco pontos que satisfaçam, simultaneamente, as duas condições anteriores.

Se as fissuras aparecerem em um rolinho com diâmetro maior que $3 \mathrm{~mm}$, o resíduo já está no estado semi-sólido e não na interface entre os estados plástico e semi-sólido. Nesse caso, acrescenta-se água ao material, homogeneíza-se e repete-se o procedimento descrito. Se o rolinho atingir um diâmetro menor que $3 \mathrm{~mm}$ sem fissuras, o resíduo ainda se encontra no estado plástico. Utilizar uma espátula para revolver a pasta de resíduo, na própria placa e com isso retirar um pouco da umidade do resíduo. A seguir refazer o ensaio.

Tendo-se o teor de umidade de cada ponto calcular a média aritmética desses valores, bem como, o desvio de $\pm 5 \%$ da média. Se um ou mais dos valores dos teores de umidade dos pontos caírem fora desse intervalo eles deverão ser desprezados e uma nova média e o valor do desvio, novamente calculados. A definição do limite de plasticidade de um solo deverá ser pela média de pelo menos três determinações. Caso isso não aconteça o ensaio deverá ser refeito.

O valor da média, indicativo do limite de plasticidade, é levado ao inteiro mais próximo e apresentado em forma de percentual. A Tabela 14 mostra o resultado do limite de plasticidade do resíduo da Rigesa.

\begin{tabular}{|l|c|c|c|}
\hline Cápsula no & 30 & 59 & 67 \\
\hline Peso úmido +tara(g) & 39,07 & 50,40 & 39,24 \\
\hline Peso seco + tara(g) & 38,58 & 49.95 & 38,70 \\
\hline Tara (g) & 38.37 & 49,75 & 38,48 \\
\hline Peso da água (g) & 0,49 & 0,45 & 0,54 \\
\hline Peso seco & 0,21 & 0,20 & 0,23 \\
\hline Umidade (\%) & 231,13 & 21,67 & 241,14 \\
\hline Umidade média & & 233,00 \\
\hline
\end{tabular}

Tabela 14 - Resultados do ensaio de plasticidade. 
Os ensaios de limite de Atterberg com o resíduo são de difícil execução devido ao alto teor de umidade do material, além do alto teor de fibras que constitui o resíduo. As fibras dificultam a formação de uma superfície lisa e as fibras também atrapalham o aparecimento das fissuras no ensaio de plasticidade, sendo assim os resultados não pode ser interpretado em termos de classificação geotécnica (LaPlante;1993).

Moo-Young e Zimmie (1996) também encontraram dificuldades e inconsistência durante os ensaios de limite de consistência, para os resíduos de papel. Em geral, os limites de Atterberg são questionáveis para sua utilização como parâmetro geotécnico do resíduo de papel.

\subsection{Ensaios de Compactação}

\subsubsection{Ensaio de Compactação Proctor Normal}

A compactação de um solo é sua densificação por meio de equipamento mecânico.

A compactação objetiva os seguintes aspectos: aumentar a intimidade de contato entre os grãos e tornar o material mais homogêneo. $O$ aumento da densidade ou redução do índice de vazios é desejável não por si, mas porque diversas propriedades do solo melhoram com isso (Pinto, 2000). As propriedades de maior interesse são: resistência, compressibilidade e permeabilidade.

A maneira pela qual optou-se pela realização deste ensaio para o resíduo do papel foi partindo-se de uma amostra única úmida secando-a para cada ponto.

Será descrito o procedimento do ensaio de compactação para uma energia igual ao do Proctor Normal, para isso foi utilizado o cilindro e o soquete, com as seguintes características: Volume útil do cilindro $1000 \mathrm{~cm}^{3}$, massa do 
soquete $2,50 \mathrm{~kg}$, altura de queda do soquete $0,305 \mathrm{~m}$, número de camadas três e número de golpes por camada 26 , resultando uma energia de compactação por unidade de volume igual a $583 \mathrm{~kJ} / \mathrm{m}^{3}$.

Os ensaios foram realizados partindo-se do ramo úmido para o seco. Este procedimento foi adotado devido à dificuldade na homogeneização do material partindo-se da condição seca ao ar. Comportamento semelhante foi observado por Moo-Young e Zimmie (1996).

Após este procedimento, com o cilindro previamente preparado e colocado sobre uma base rígida, colocou-se uma quantidade de resíduo solto no cilindro e com o soquete padronizado compactou-se a primeira camada. Os golpes aplicados com o soquete, que tem a sua base junto ao resíduo, mas não apoiados nele, foram sendo distribuídos uniformemente sobre a área do cilindro, de tal forma, a resultar uma superfície plana e horizontal, garantindo assim uma aplicação uniforme da energia. A altura da camada compactada foi, aproximadamente, igual a um terço da altura final total do corpo de prova.

Após a compactação da primeira camada verificamos a altura da camada compactada e foi feita uma ligeira escarificação no topo da camada compactada, de forma a permitir um entrosamento maior entre as duas camadas. Colocou-se mais resíduo no cilindro e repetiu-se o procedimento usado na compactação da primeira camada e assim também, para a terceira camada. As três camadas devem ficar com espessura aproximadamente iguais, e a camada de resíduo acima do cilindro de compactação, não deve ter uma espessura superior a $10 \mathrm{~mm}$, sob pena do resultado desse ponto não poder ser aproveitado para o traçado da curva de compactação. Terminada a operação de compactação do primeiro ponto, o colar e o excesso de resíduo foi retirados, usando um arco de serra e procurou-se deixar o corpo de prova com o mesmo volume do cilindro. O que não é muito fácil, pois as fibras não permitem a formação de uma camada lisa e plana. 
Em seguida, foi determinada a massa do conjunto resíduo-cilindro, levandoo depois para um extrator de amostra para a retirada do corpo de prova. Após este procedimento determinou-se o teor de umidade para este ponto, retirando do interior do corpo de prova uma porção de resíduo para determinação de três teores de umidades. Sendo assim, foi obtido o teor de umidade da amostra compactada, correspondente ao primeiro ponto da curva massa específica seca - teor de umidade. Repetiu-se a operação para os demais pontos secando a amostra.

Durante a secagem do resíduo ao ar até uma umidade abaixo de aproximadamente $40 \%$, formaram grandes torrões, que foram difíceis de serem rompidos e o resíduo perdeu a plasticidade inicial. Foram executados ensaios onde durante a secagem o material era passado na peneira número 4 e outro onde não se peneirava o material, e os resultados foram muito próximos.

Para o resíduo da Rigesa foi difícil a determinação do lado seco da curva de compactação. O tempo de ensaio demorou semanas e quanto mais o resíduo era seco ocorria a formação de torrões. Estes torrões eram difíceis de serem destorroados, dificultando a compactação.

A Figura 34 apresenta os resultados obtidos no ensaio de compactação. Observa-se que não há uma boa caracterização da máxima densidade. Com base nos resultados adotou-se como teor de umidade ótimo do resíduo da Rigesa $50 \%$ e a densidade seca máxima $6,35 \mathrm{kN} / \mathrm{m}^{3}$. 


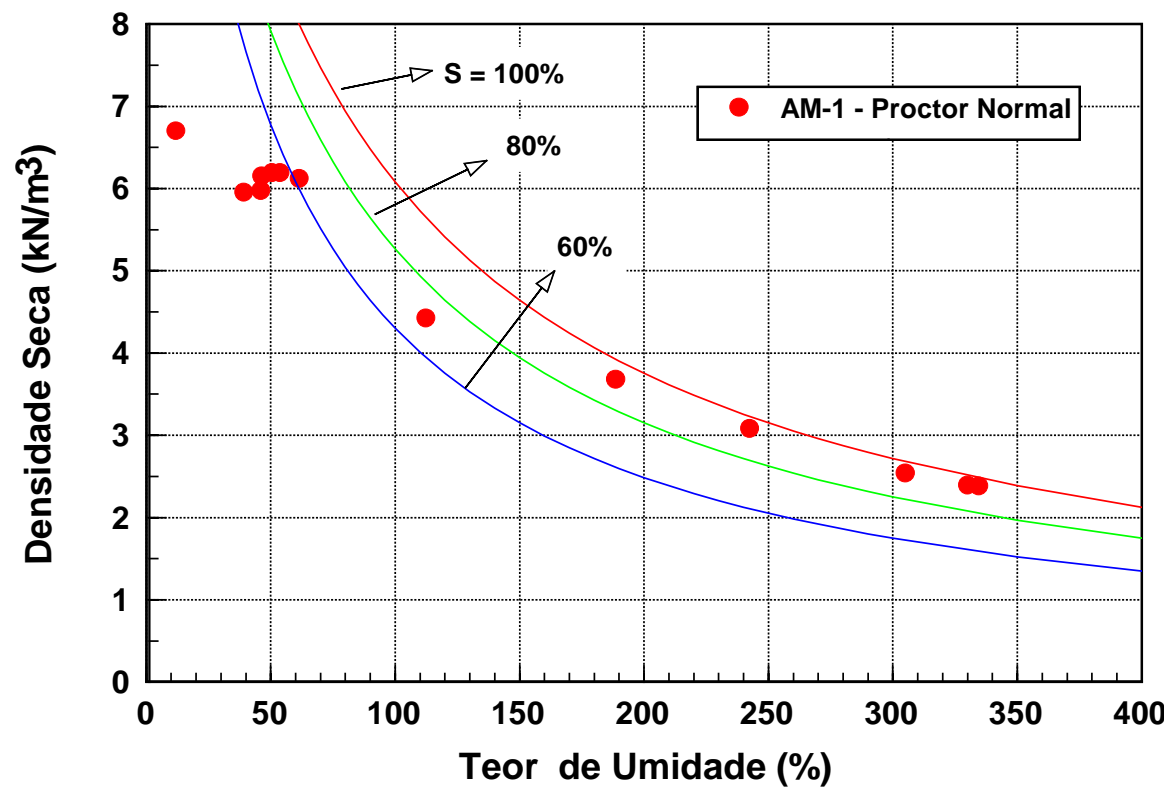

Figura 34 - Curva de compactação Proctor Nornal do resíduo da Rigesa.

A Figura 35 apresenta a fotografia dos corpos de prova do resíduo da Rigesa após a compactção no Proctor Normal. A amostra da esquerda foi compactada no lado seco e a da direita compactada no lado úmido em relação ao teor de umidade ótima. Macro poros podem ser observados para a amostra compactada no lado seco.

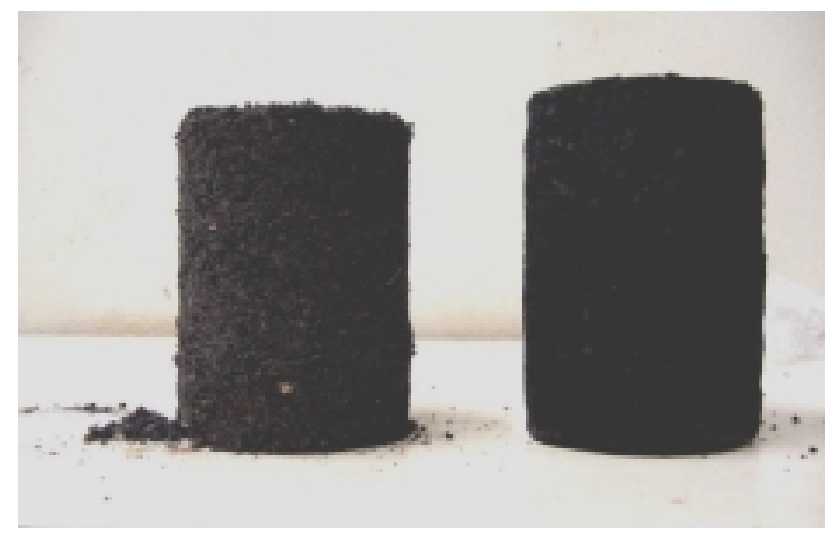

Figura 35 - Corpo de prova da Rigesa compactado do lado seco e do lado úmido. 


\subsubsection{Ensaio de Compactação Molde Reduzido}

Este processo de compactação e moldagem de corpo de prova é bastante simples, e de operação mais rápida e econômica do que os processos tradicionais. O principal objetivo de se usar este processo nesta pesquisa foi facilitar a compactação das amostras, e também pela necessidade de se utilizar uma quantidade menor de material, o que facilitou na rápida secagem do mesmo. Assim sendo, este ensaio não veio substituir o ensaio de compactação normal, mas o de facilitar a obtenção das amostras para a curva de retenção.

O equipamento de ensaio é mostrado na figura 36 . O equipamento consiste dos seguintes itens:

1. Cilindro e colar: Os corpos de prova moldados por este processo têm $5 \mathrm{~cm}$ de diâmetro e $5 \mathrm{~cm}$ de altura. $O$ cilindro de moldagem tem, portanto, $5 \mathrm{~cm}$ de diâmetro e altura superior de maneira a receber 0 solo solto. O colar facilita a colocação do solo solto antes da compactação.

2. Base de moldagem: A base de moldagem possui local para assentamento do cilindro e apoio do soquete.

3. Soquete: A compactação se faz com um peso de $2.250 \mathrm{~g}$ caindo de uma altura de $305 \mathrm{~mm}$. O peso cai sobre uma peça com $49 \mathrm{~mm}$ de diâmetro que se apoia diretamente sobre o solo colocado no cilindro.

4. Suporte temporário: o suporte é usado para apoio do cilindro na base. Ele só é empregado até ser aplicado o primeiro golpe do soquete sobre o solo, sendo então removido. A partir do segundo golpe, portanto, as duas extremidades do cilindro ficam livres e a compactação se faz pelo método do pistão duplo.

5. Extrator: Constituído de um apoio para o cilindro e um macaco hidráulico que permite a retirada do corpo de prova compactado de dentro do cilindro. 
6. Medidor de altura: Uma base para colocação do corpo de prova e um deflectômetro são usados para medir a altura do corpo de prova. $O$ deflectômetro é ajustado de maneira a acusar uma altura conhecida quando o corpo de prova tiver $5 \mathrm{~cm}$ de altura. Por diferença se fica conhecendo a altura de cada corpo de prova.
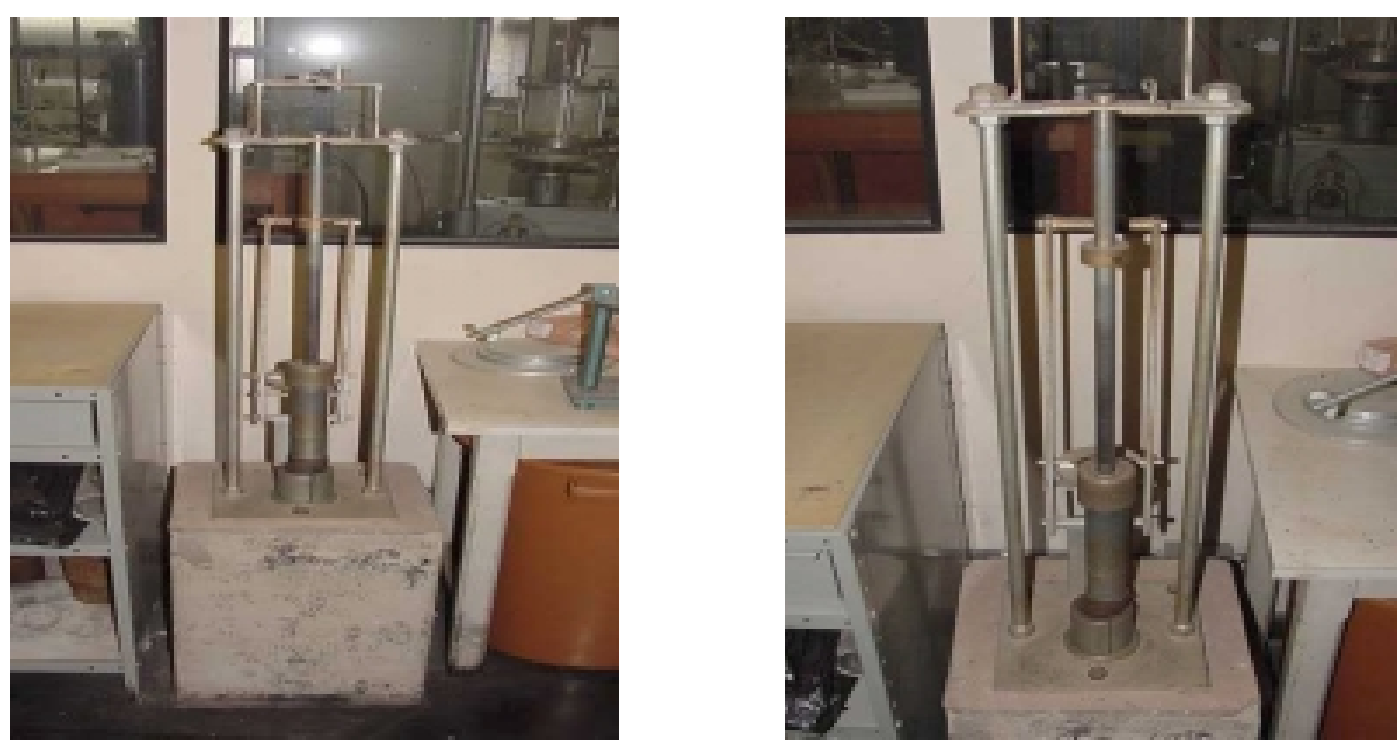

Figura 36 - Foto do equipamento do ensaio de compactação molde reduzido.

A moldagem do corpo de prova é feita conhecendo a densidade máxima e a umidade ótima da mistura pelo ensaio de proctor normal, os corpos de prova são moldados da seguinte forma: prepara-se a mistura com a umidade ótima, pesa-se uma quantidade de mistura igual ao peso que 0 corpo de prova de $5 \mathrm{~cm}$ por $5 \mathrm{com}$ deve ter na densidade máxima. Este peso é dado pela fórmula:

$$
P=\rho d(1+w) V
$$

Onde:

- $\rho d=$ densidade seca máxima em $\mathrm{g} / \mathrm{cm}^{3}$;

- $\mathrm{w}=$ umidade da mistura;

- $\mathrm{V}=$ volume do corpo de prova $\left(98,2 \mathrm{~cm}^{3}\right)$ 
Coloca-se a mistura no cilindro apoiado no suporte temporário. Aplica-se um golpe do soquete, retira-se o suporte temporário e aplicam-se mais quatro golpes do soquete. Retira-se o colar, inverte-se a posição do cilindro sobre a base, e aplicam-se mais cinco golpes do soquete.

Retira-se o corpo de prova do cilindro por meio do extrator. Pesa-se o corpo de prova. Mede-se a altura do corpo de prova com o medidor e calcula-se seu volume.

Da mistura preparada retira-se uma amostra para determinação da umidade. Com os dado obtido de peso, altura e umidade determina-se a densidade seca do corpo de prova.

A aplicação de cinco golpes do soquete em cada lado do corpo de prova, compacta-o a uma densidade muito próxima da densidade máxima do ensaio de Proctor Normal.

Este método utilizado para o resíduo de papel forneceu uma curva de compactação muito próxima da curva de compactação do Proctor Normal, sendo seu uso muito mais rápido e apresentando uma economia de material, facilitando assim a secagem do mesmo e ganhando tempo em relação ao ensaio de proctor normal.

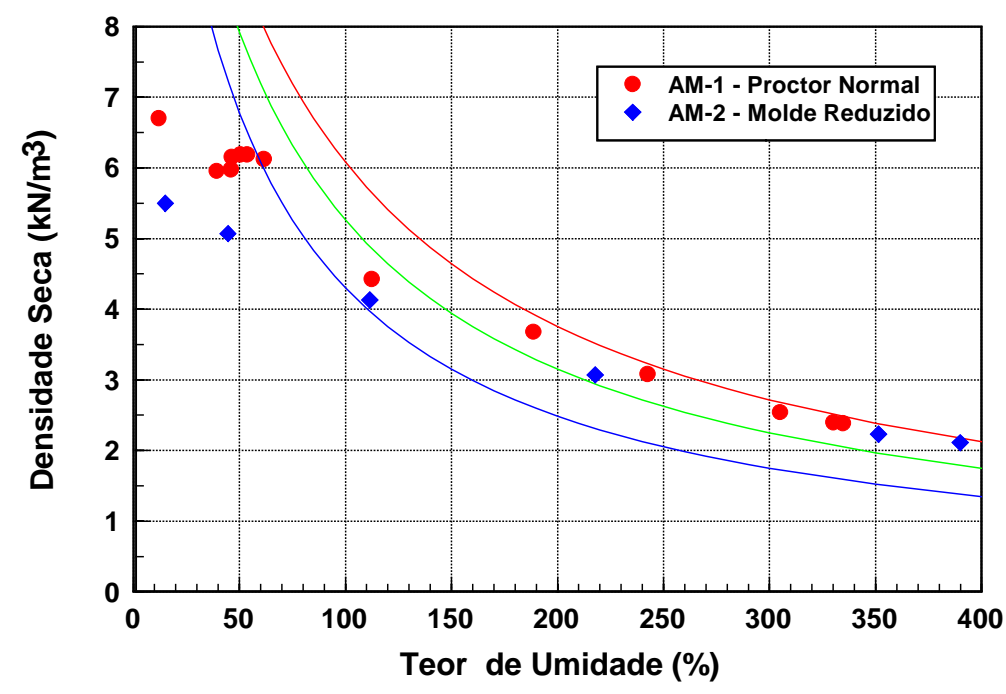

Figura 37 - Ensaio de compactação proctor normal e molde reduzido. 
Observa-se, no entanto, que para o teor de umidade de $50 \%$ a densidade seca obtida foi inferior aquela do ensaio de Proctor normal.

\subsection{Ensaio de Adensamento}

O comportamento dos solos perante os carregamentos depende da sua constituição e do estado em que o solo se encontra, e pode ser expresso por parâmetros que são obtidos em ensaios ou através de correlações estabelecidas entre estes parâmetros e as diversas classificações (Pinto, 2000).

O ensaio empregado para a determinação da deformabilidade do resíduo foi o ensaio de compressão edométrica. O ensaio de compressão edométrica consiste na compressão do resíduo contido dentro de um molde que impede qualquer deformação lateral.

Para a execução do ensaio compactou-se uma amostra através do processo de Proctor Normal, onde após sua extração do cilindro, talhou-se o corpo de prova de modo que se preencheu totalmente os vazios do anel de adensamento. Com uma faca, nivelou o topo e a base do anel, tomando-se o cuidado de deixar nivelados os mesmos. Após a talhagem do corpo de prova, com a material restante da talhagem, foram determinados o teor de umidade da amostra, e o peso do conjunto anel de adensamento e amostra. Mediu-se a altura e o diâmetro do corpo de prova.

Após a pesagem do anel com o corpo de prova foi montada a célula de adensamento, as pedras porosas e os papéis-filtro. As pedras porosas foram previamente fervidas e mantidas imersas em água, até o instante de entrar em contato com a amostra. À montagem da célula de adensamento obedeceu-se a seguinte seqüência: base rígida, pedra porosa inferior, papel filtro, corpo de prova contido no anel, papel filtro e pedra porosa superior. 
Uma vez colocado o anel com o corpo de prova na prensa, e acertado o extensômetro, procedeu-se ao primeiro carregamento, que é da ordem de 10 $\mathrm{kPa}$, Optou-se por este carregamento, pois a norma recomenda para solos moles esta ordem de carregamento. Como o resíduo tem características de solos moles, este carregamento inicial, evitou a expulsão do resíduo. O ensaio foi executado com inundação do corpo de prova imediatamente após a aplicação do carregamento de $0,10 \mathrm{~kg} / \mathrm{cm}^{2}$, enchendo o reservatório com água destilada.

Os acréscimos de carga para os estágios subseqüentes foram de $100 \%$, isto é, dobrou-se a carga do estágio anterior. As leituras foram feitas em intervalos de tempo compatíveis com a escala logaritmo: 1/8, 1/4, 1/2 segundo e $1,2,4,8,15$ e 30 minutos e $1,2,4,8$ e 24 horas. $O$ descarregamento foi feito com decréscimos de carga de $50 \%$ em relação ao carregamento anterior. Para o descarregamento optou-se em executar as leituras nos mesmos intervalos de tempo, utilizadas para o carregamento. Após o ensaio determinou-se o teor de umidade e o peso seco da amostra, bem como a altura final do corpo de prova.

A Tabela 15 apresenta os dados iniciais da amostra no ensaio de adensamento bem como o índice de compressão obtido em cada ensaio. Saliente-se que o índice de compressão foi determinado no intervalo entre $100 \mathrm{kPa}$ e $1000 \mathrm{kPa}$.

\begin{tabular}{|c|c|c|c|c|}
\hline Amostra & $\begin{array}{c}\text { Teor de } \\
\text { Umidade }(\%)\end{array}$ & $\begin{array}{c}\text { Densidade } \\
\text { Seca }\left(\mathrm{Kn} / \mathrm{m}^{3}\right)\end{array}$ & $\begin{array}{c}\text { Índice de } \\
\text { Vazios }\end{array}$ & $\begin{array}{c}\text { Índice de } \\
\text { Compressão }\end{array}$ \\
\hline 1 & 51 & 6,620 & 2,71 & 0,79 \\
\hline 2 & 126 & 4,360 & 2,727 & 1,36 \\
\hline 3 & 130 & 4,250 & 2,824 & 1,2 \\
\hline
\end{tabular}

Tabela 15 - Características das amostras da Rigesa no ensaio de adensamento. 
A Figura 38 apresenta a fotografia da amostra 1(esquerda) e 2(direita) da Rigesa após o ensaio de adensamento. Na amostra da esquerda observa-se macro poroso, pois a amostra foi compactada do lado seco da curva de compactação. A amostra da direita foi compactada com um teor de umidade de $126 \%$ e a da esquerda com $51 \%$.
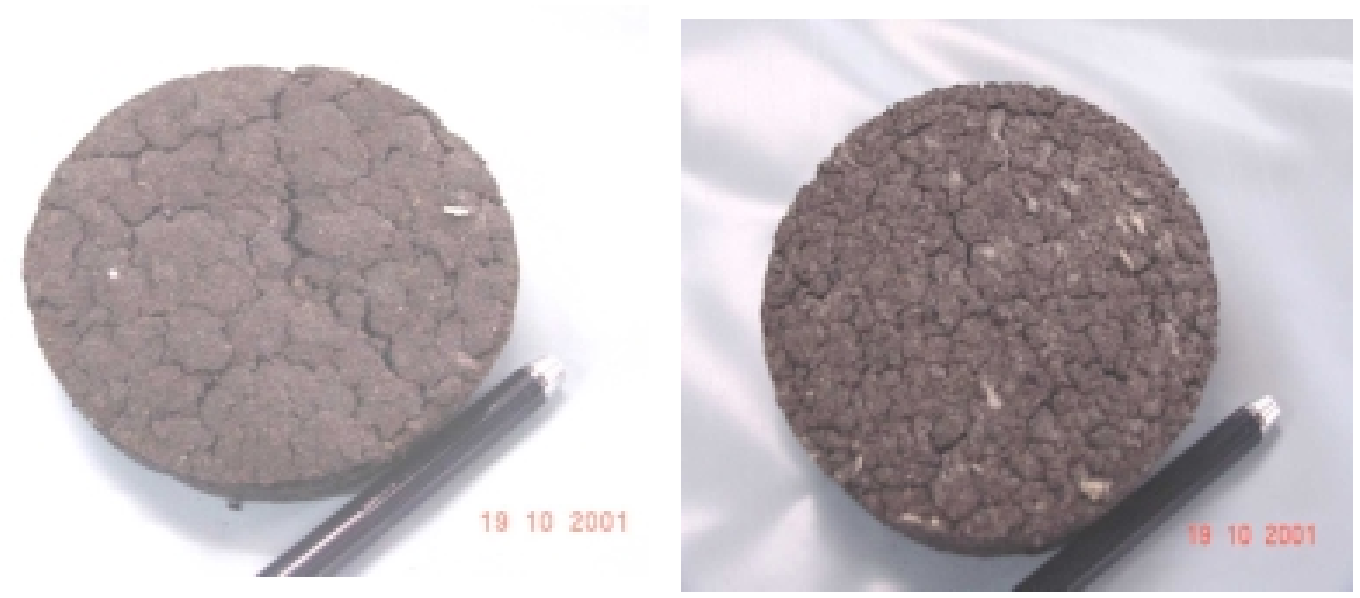

Figura 38 - Amostra da Rigesa no ensaio de adensamento após secagem em estufa.

Os resultados dos ensaios de adensamento obtidos com as amostras 1,2 e 3 estão apresentados nas Figura 39, 40 e 41. Nestas Figuras são apresentadas as relações entre índices vazios com o tempo e com a tensão aplicada. 
4. Metodologia de Ensaio
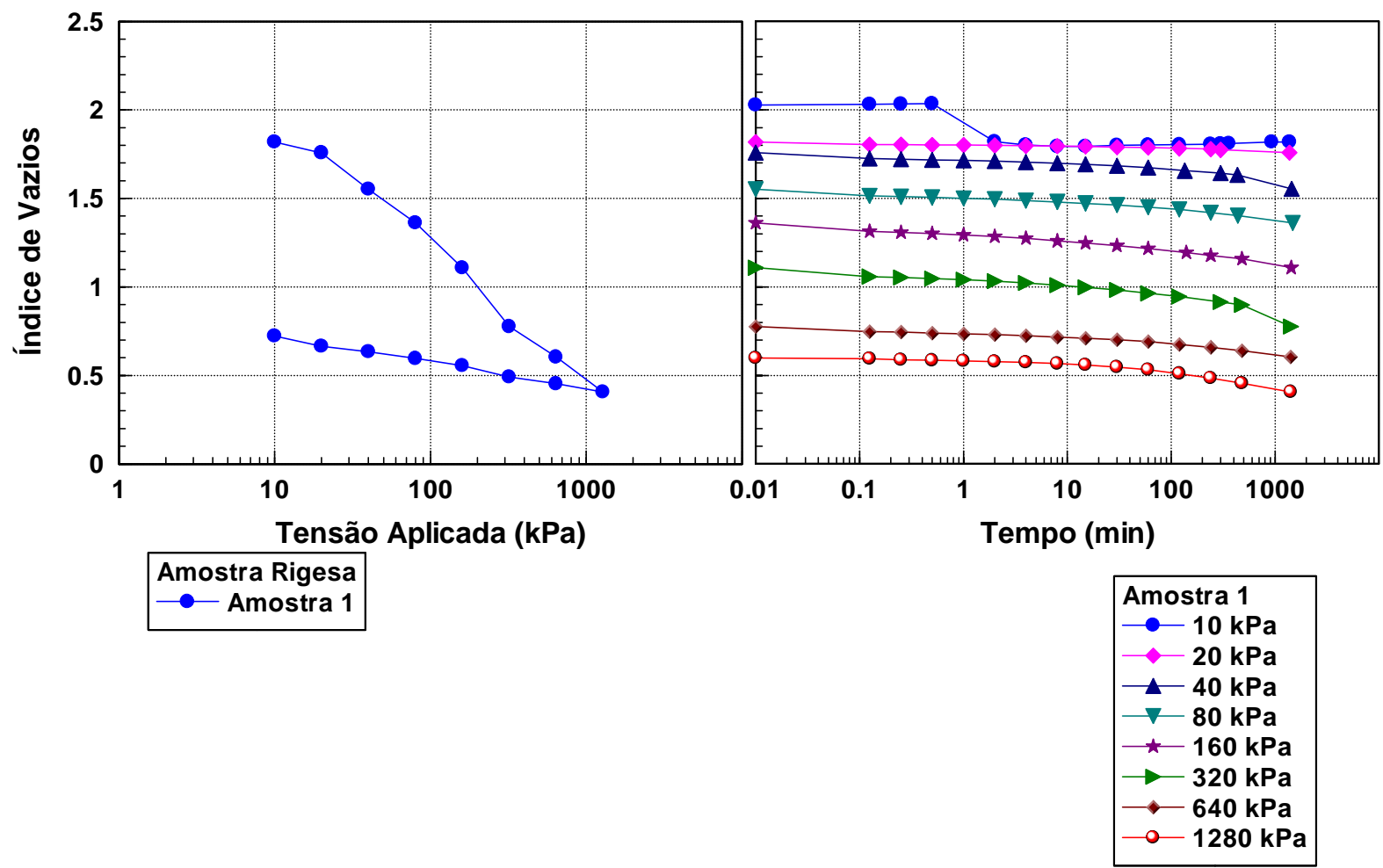

Figura 39 - Curvas do ensaio de adensamento da amostra 1 da Rigesa.
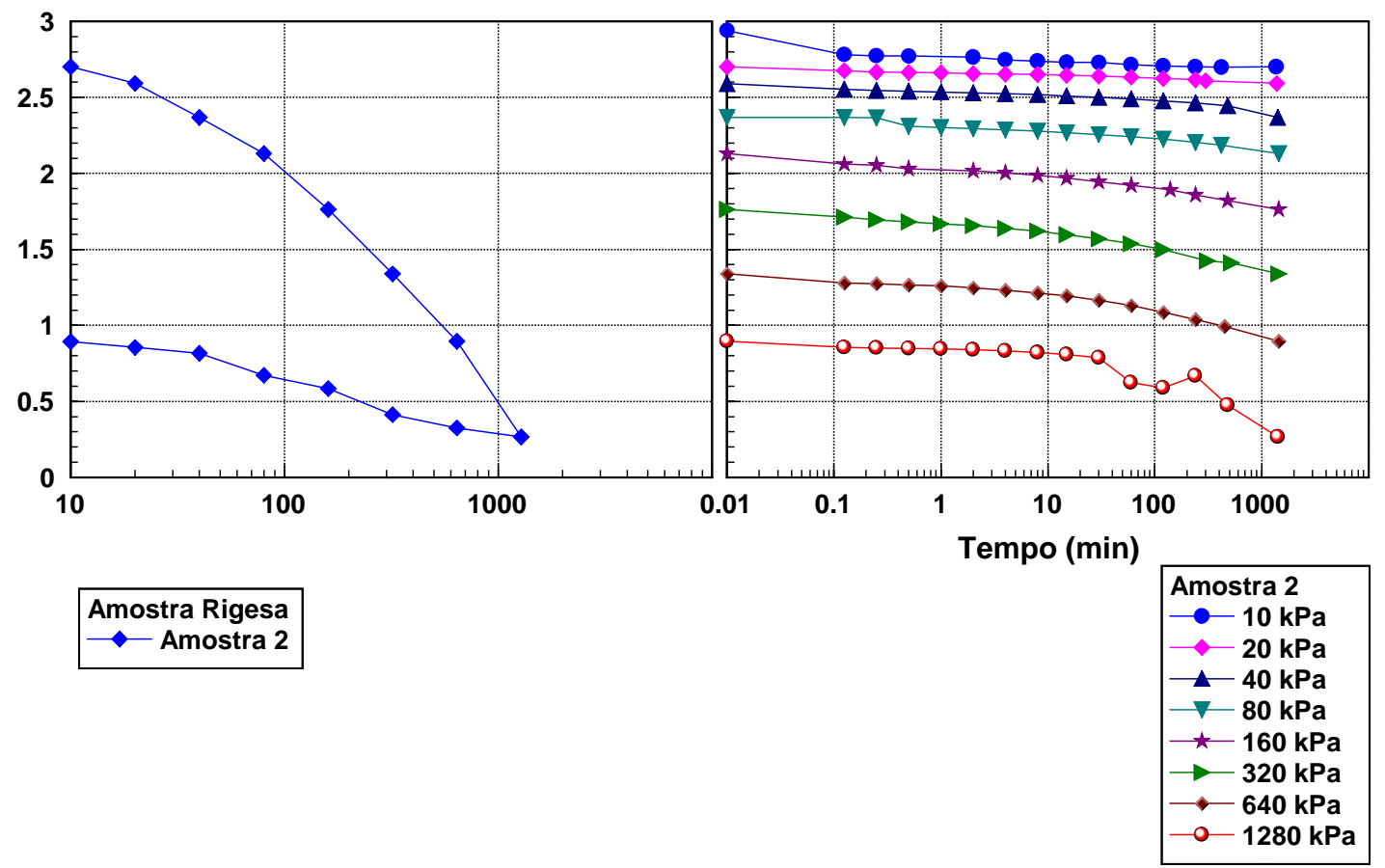

Figura 40 - Curvas do ensaio de adensamento da amostra 2 da Rigesa. 


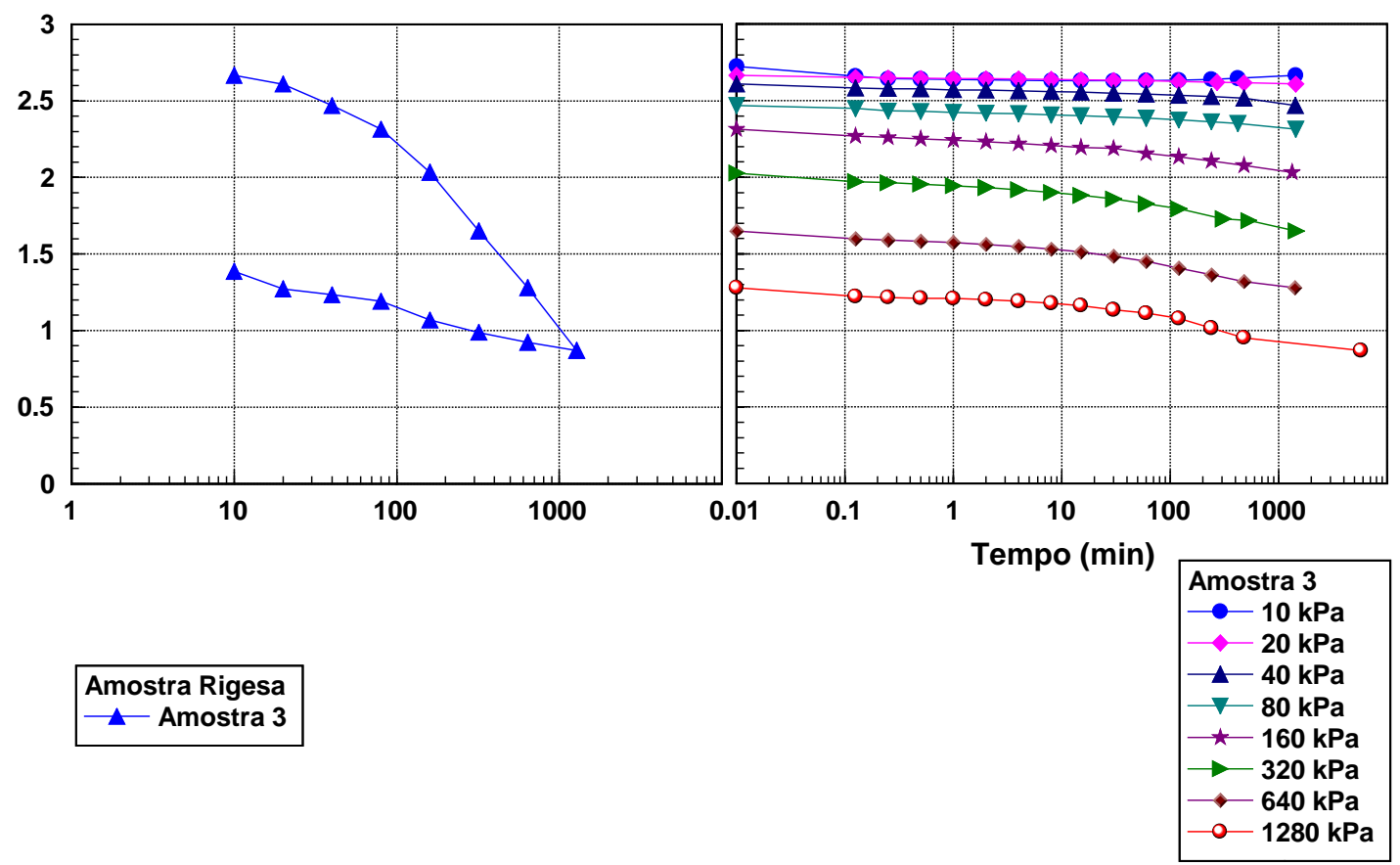

Figura 41 -Curvas do ensaio de adensamento da amostra 3 da Rigesa.

Analisando as curvas de índice de vazios versus tempo observou-se que o deslocamento em 24 horas não se estabilizava. Assim, optou-se em controlar os carregamentos aplicados através da velocidade de recalque versus tempo. Quando a velocidade se mantém constante dobrava-se a carga aplicada para iniciar o próximo estágio de carregamento.

Uma nova série de ensaios foi feita com o procedimento de carregamento acima descrito. As amostras foram compactadas através do método de Proctor normal com uma umidade aproximadamente de $131 \%$. Na tabela 16 apresentamos os dados iniciais das amostras e os índices de compressão obtidos. 


\begin{tabular}{|c|c|c|c|c|}
\hline Amostra & $\begin{array}{c}\text { Teor de } \\
\text { Umidade }(\%)\end{array}$ & $\begin{array}{c}\text { Densidade } \\
\text { Seca }\left(\mathrm{Kn} / \mathrm{m}^{3}\right)\end{array}$ & $\begin{array}{c}\text { Índice de } \\
\text { Vazios }\end{array}$ & $\begin{array}{c}\text { Índice de } \\
\text { Compressão }\end{array}$ \\
\hline 4 & 131 & 3,370 & 3,822 & 1,45 \\
\hline 5 & 131 & 3,330 & 3,880 & 1,87 \\
\hline 6 & 131 & 3,660 & 3,440 & 1,88 \\
\hline
\end{tabular}

Tabela 16 -Característica da amostra da Rigesa para o ensaio de adensamento.

Os resultados dos ensaios de adensamento realizados com as amostras 4, 5 e 6 estão apresentados nas Figuras 42, 43 e 44. Nestas Figuras são apresentadas as relações entre índices vazios com o tempo e com a tensão aplicada.
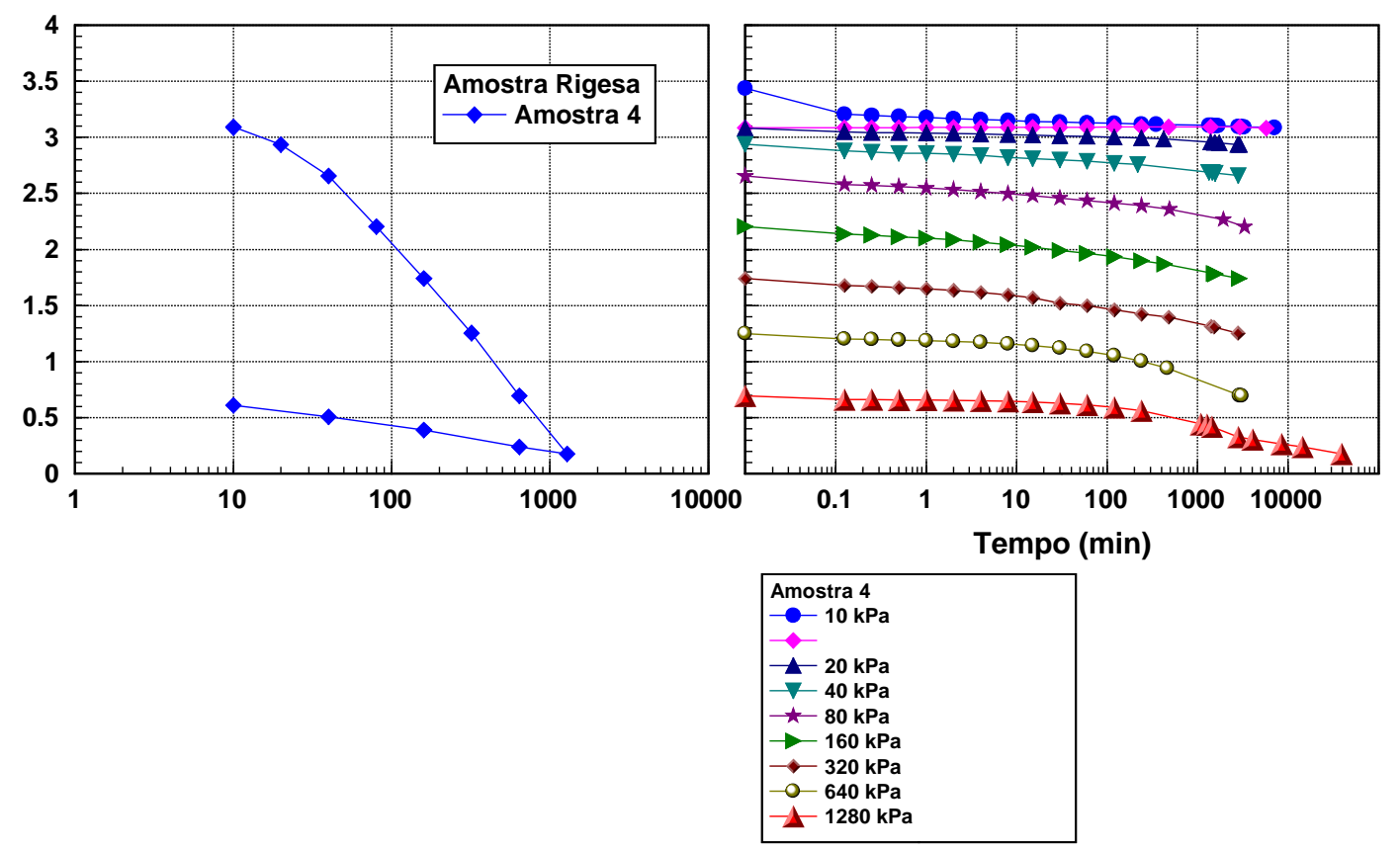

Figura 42 - Curva do ensaio de adensamento amostra 4. 
4. Metodologia de Ensaio
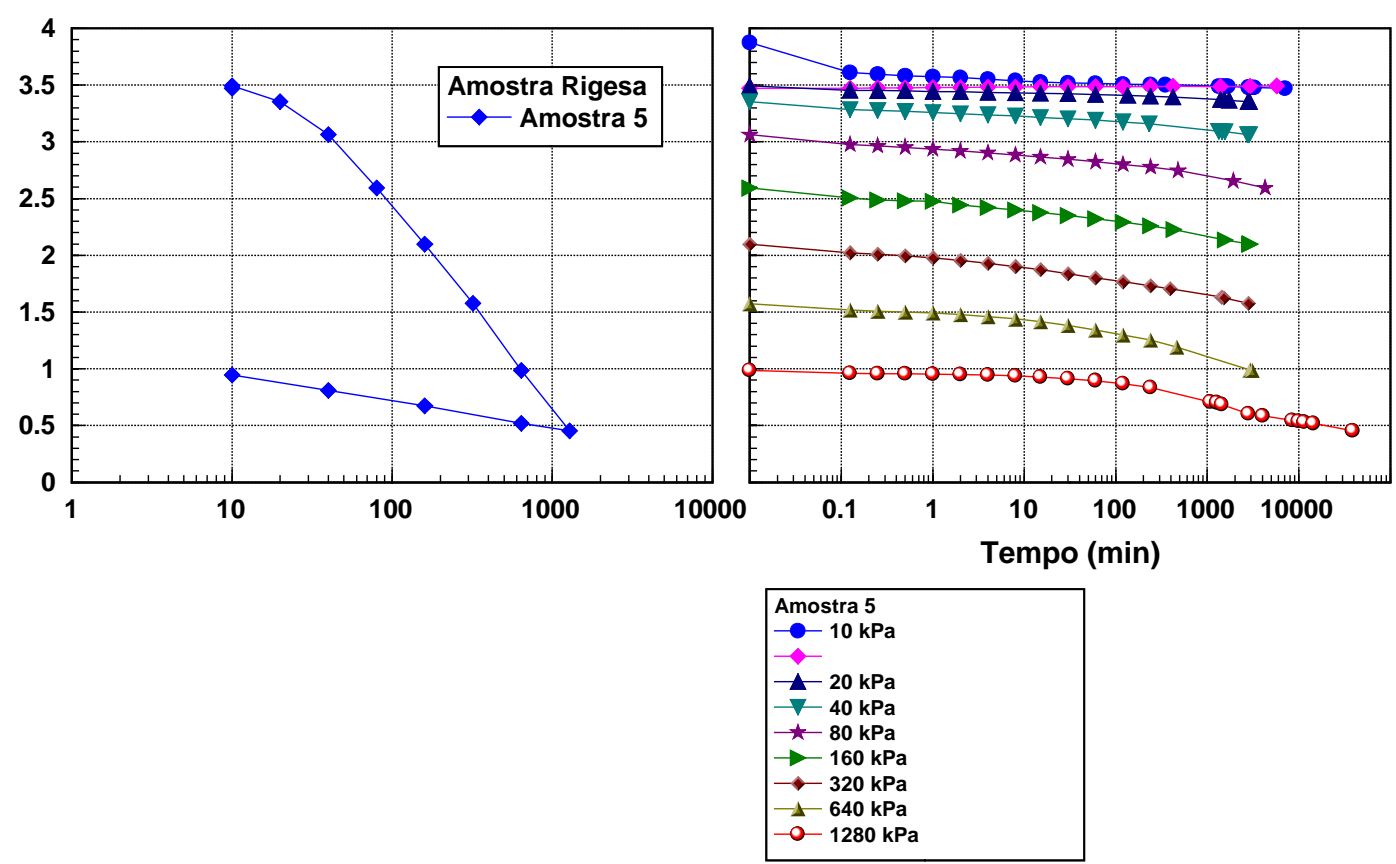

Figura 43 - Curvas dos ensaios de adensamento amostra 5.
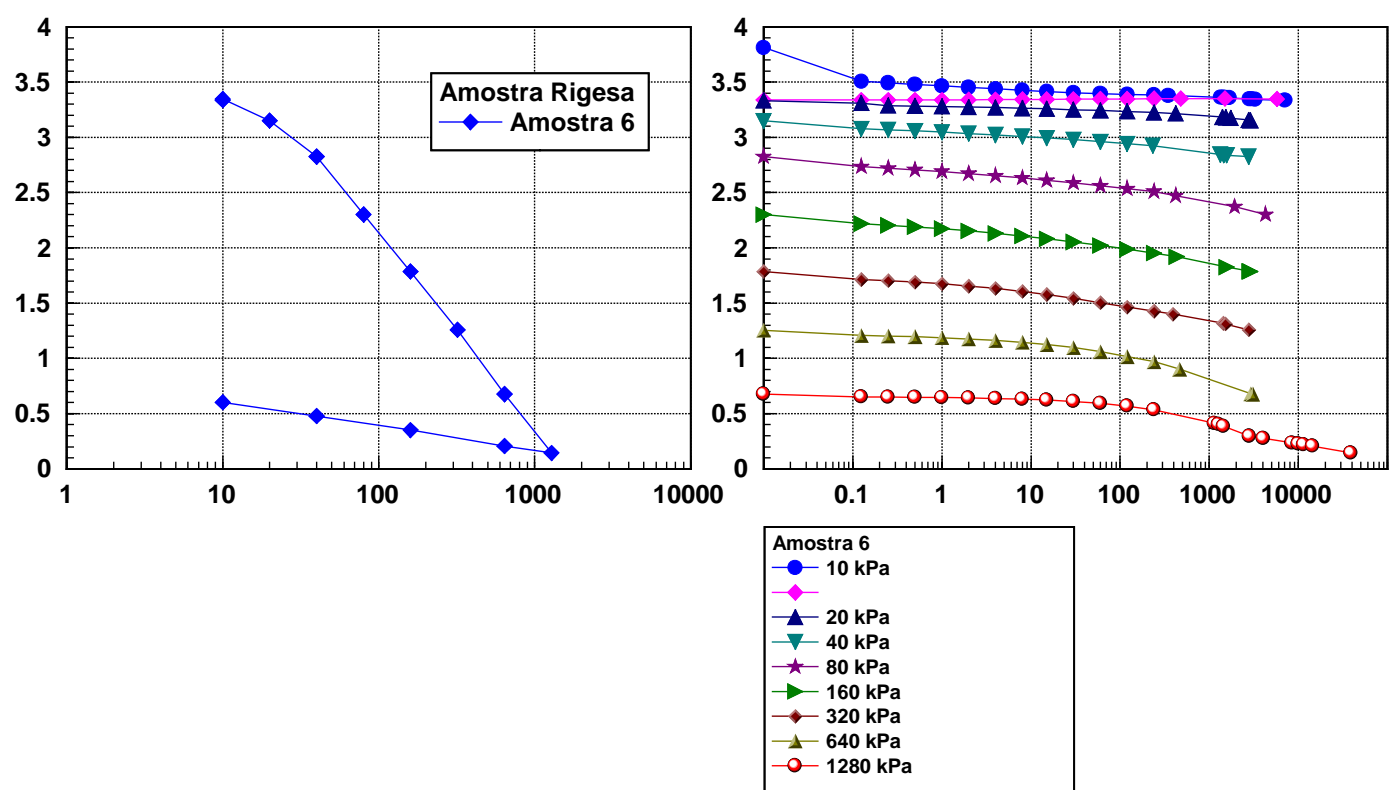

Figura 44 - Curvas dos ensaios de adensamento amostra 6.

As amostras da segunda série (amostras 4, 5 e 6) apresentaram índice de vazios inicial muito superior aos da primeira série. 


\subsection{Ensaio de Permeabilidade}

O ensaio utilizado para determinar a condutividade hidráulica do resíduo de papel foi o ensaio de permeabilidade de carga variável.

O ensaio de permeabilidade carga variável foram executados concomitantemente ao ensaio de adensamento, nos estágios de tensão de $10,40,160,640 \mathrm{kPa}$, após o recalque total da amostra.

Os ensaios foram executados em amostras compactadas em proctor normal as características iniciais da amostra estão apresentadas na Tabela 17.

Para a execução do ensaio foi acoplando uma bureta ao anel de adensamento com diâmetro conhecido. Utilizando um cronômetro mediu-se o tempo de percolação da água através da amostra. Foram feitas oito determinações para cada estágio de tensão em cada amostra. A Lei de Darcy foi utilizada para calcular a permeabilidade da amostra. A média das determinações calculadas foi a permeabilidade encontrada para o resíduo de papel da Rigesa.

\begin{tabular}{|c|c|c|c|}
\hline Amostra & $\begin{array}{c}\text { Teor de Umidade } \\
(\%)\end{array}$ & $\begin{array}{c}\text { Densidade Seca } \\
\left(\mathrm{Kn} / \mathrm{m}^{3}\right)\end{array}$ & $\begin{array}{c}\text { Índice de } \\
\text { Vazios }\end{array}$ \\
\hline 4 & 131 & 3,370 & 3,081 \\
\hline 5 & 131 & 3,330 & 3,495 \\
\hline 6 & 131 & 3,660 & 3,348 \\
\hline
\end{tabular}

Tabela 17 - Características das amostras da Rigesa no ensaio de permeabilidade.

A Figura 45 apresenta os resultados dos ensaios de permeabilidade associados com o ensaio de adensamento. Observou-se uma pequena diminuição do coeficiente de permeabilidade com a redução do índice de vazios. A amostra apresentou uma maior variação na permeabilidade. 


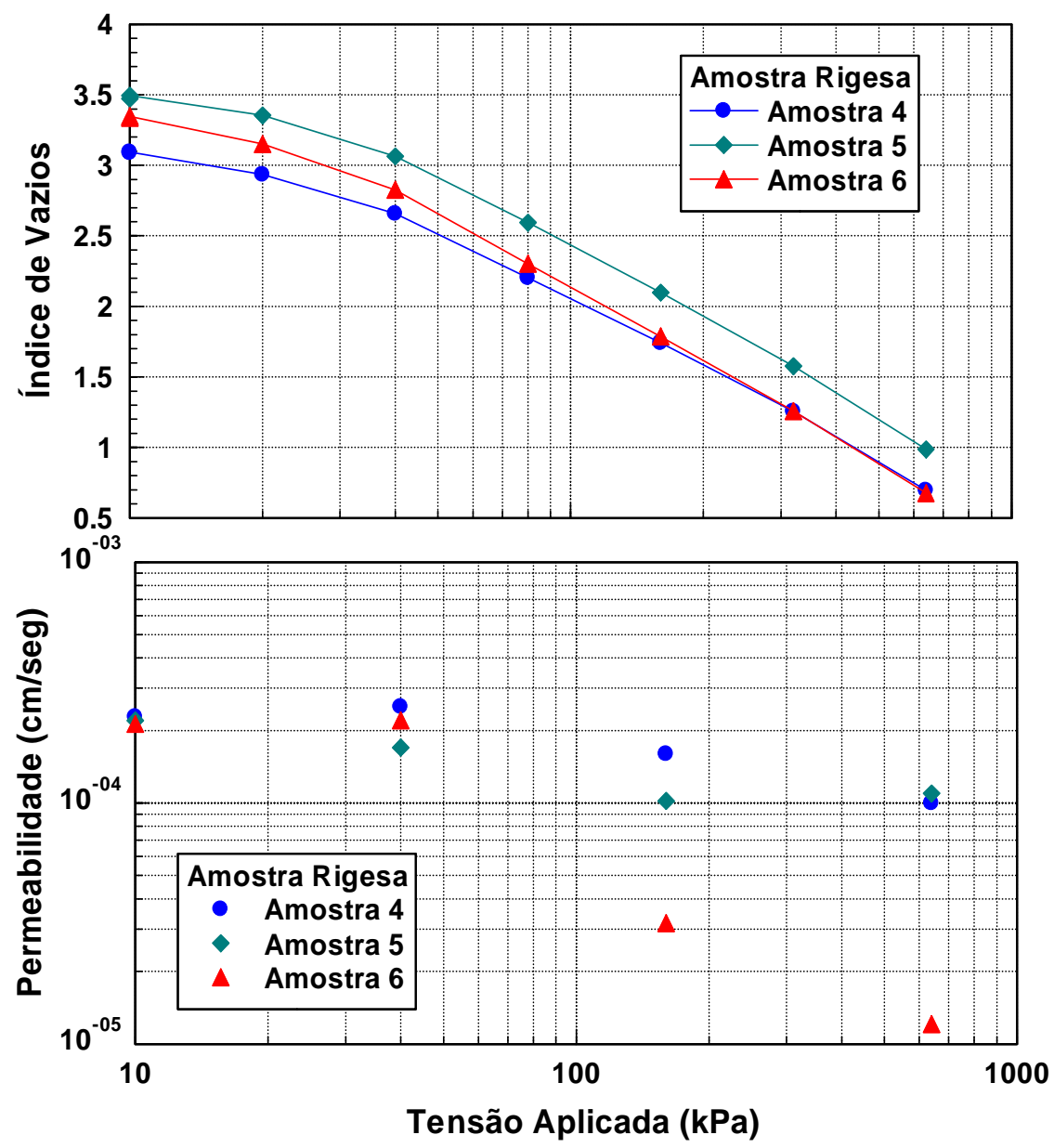

Figura 45 - Resultados de ensaios de permeabilidade para as amostras de resíduo da Rigesa.

\subsection{Ensaio de Cisalhamento Direto}

O ensaio de cisalhamento direto é o mais antigo procedimento para a determinação da resistência ao cisalhamento e se baseia diretamente no Critério de Coulomb (Pinto, 2000).

Os ensaios de cisalhamento direto foram realizados em amostras compactadas no molde do Proctor. As amostras foram talhadas diretamente no molde do ensaio de cisalhamento. Com uma faca arrasou-se o topo e a base do anel, tomando-se o cuidado de deixar nivelado os mesmos. Após a 
talhagem do corpo de prova, com o material restante da talhagem, foi determinado o teor de umidade da amostra.

A montagem da caixa de cisalhamento direto obedeceu à seguinte seqüência: caixa de cisalhamento, pedra porosa inferior, papel filtro, corpode-prova, papel filtro e pedra porosa superior. O corpo de prova foi introduzido na caixa de cisalhante aplicando-se uma pequena pressão, para a retirada do corpo de prova do molde talhador.

Após a colocação da caixa cisalhante na prensa, foram feitos os ajustes necessários dos extensômetros. Os ensaios foram realizados com tensões normais de 20,40,100, 200 e 400kPa. As leituras da fase de adensamento foram feitas em intervalos de tempo de 1/8, 1/4, 1/2 de segundo e 1, 2, 4, 8, 15 e 30 minutos e 1, 2, 4, 8 e 24 horas. Após o adensamento iniciou-se a aplicação da força horizontal de cisalhamento, onde se optou por uma velocidade de ruptura de $0,0016 \mathrm{~mm} / \mathrm{seg}$, observando ao mesmo tempo as deformações horizontais e verticais. Obteve-se assim um conjunto de pares de valores tensão normal e tensão cisalhante $(\sigma, \tau)$, que marcados em um sistema cartesiano, permite a determinação do ângulo de atrito e do intercepto de coesão.

Na Tabela 18 estão apresentados os dados iniciais dos corpos de prova ensaiados, com as respectivas tensões normais utilizadas.

\begin{tabular}{|c|c|c|c|c|}
\hline Amostra & $\begin{array}{c}\text { Teor de } \\
\text { Umidades }(\%)\end{array}$ & $\begin{array}{c}\text { Peso Específico } \\
\left(\mathrm{KN} / \mathrm{m}^{3}\right)\end{array}$ & $\begin{array}{c}\text { Índice de } \\
\text { Vazios }\end{array}$ & $\begin{array}{c}\text { Tensão } \\
\text { Normal (kpa) }\end{array}$ \\
\hline 1 & 101,88 & 3,840 & 3,232 & 100 \\
\hline 2 & 101,88 & 3,840 & 3,232 & 200 \\
\hline 3 & 96,82 & 3,730 & 3,357 & 400 \\
\hline 4 & 370,96 & 2,029 & 6,009 & 20 \\
\hline 5 & 370,96 & 2,250 & 6,222 & 40 \\
\hline
\end{tabular}

Tabela 18 - Características dos corpos de prova dos ensaios de cisalhamento direto. 
Na Figura 46 apresentam-se os resultados dos ensaios realizados. Observase que todas os corpos de prova tiveram um comportamento semelhante com relação a forma da curva tensão versus deslocamento.

A tensão cisalhante aumenta continuamente com o deslocamento. Durante o cisalhamento os corpos de prova sofreram uma contínua redução de altura.
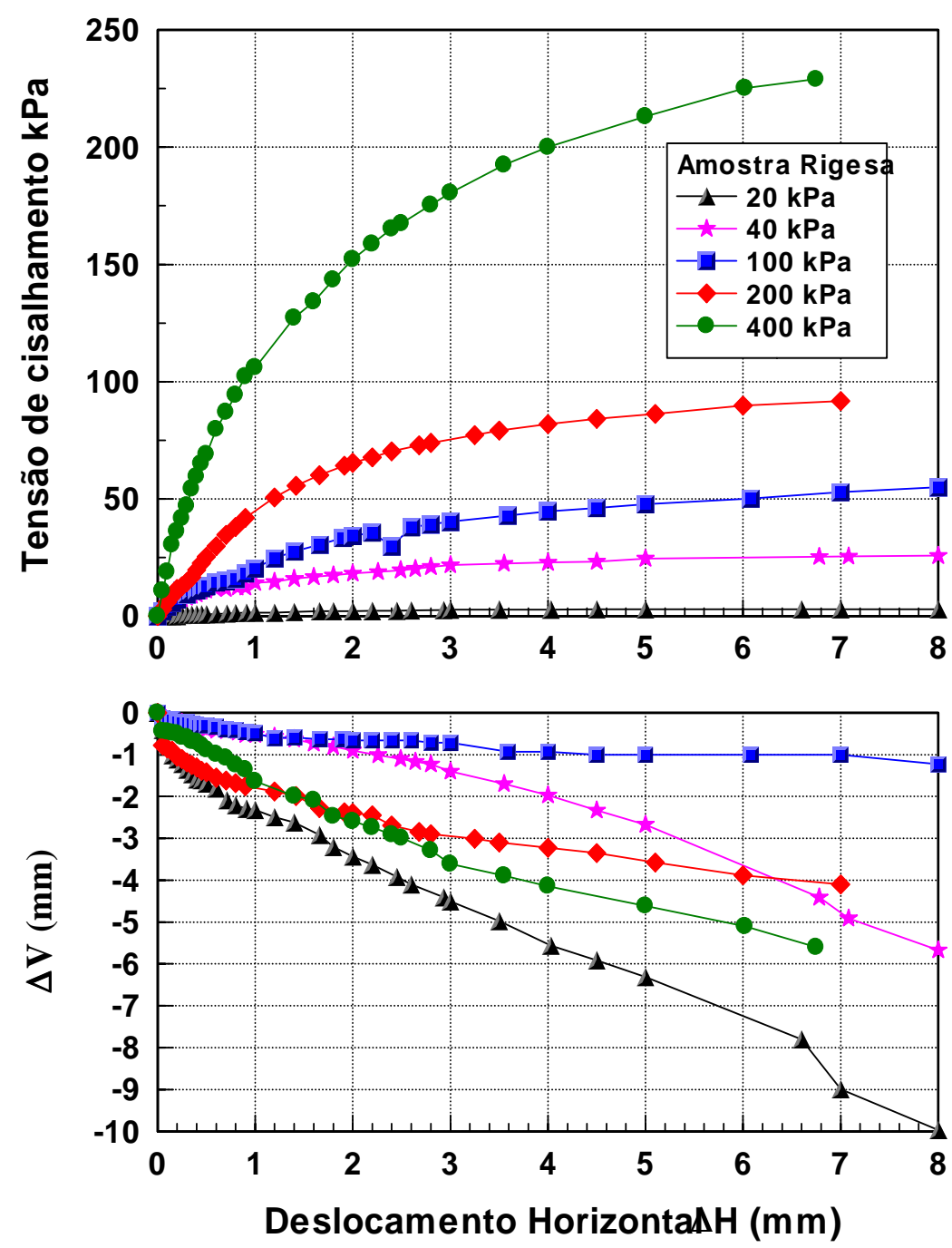

Figura 46 - Resultados do ensaio de cisalhamento direto do resíduo da Rigesa.

A envoltória de resistência obtida para o resíduo da Rigesa é apresentada na Figura 47. Observa-se que para a tensão normal de $20 \mathrm{kPa} o$ valor obtido 
sugere uma resistência extremamente baixa. Para os valores entre 40 e 200 kPa de tensão normal os resultados indicaram valores de ângulo de atrito e intercepto de coesão de $27^{\circ}$ e $0 \mathrm{kPa}$, respectivamente. O resultado para a tensão normal de $400 \mathrm{kPa}$ indicou um aumento da resistência que não concorda com a análise feita com as três tensões normais anteriores.

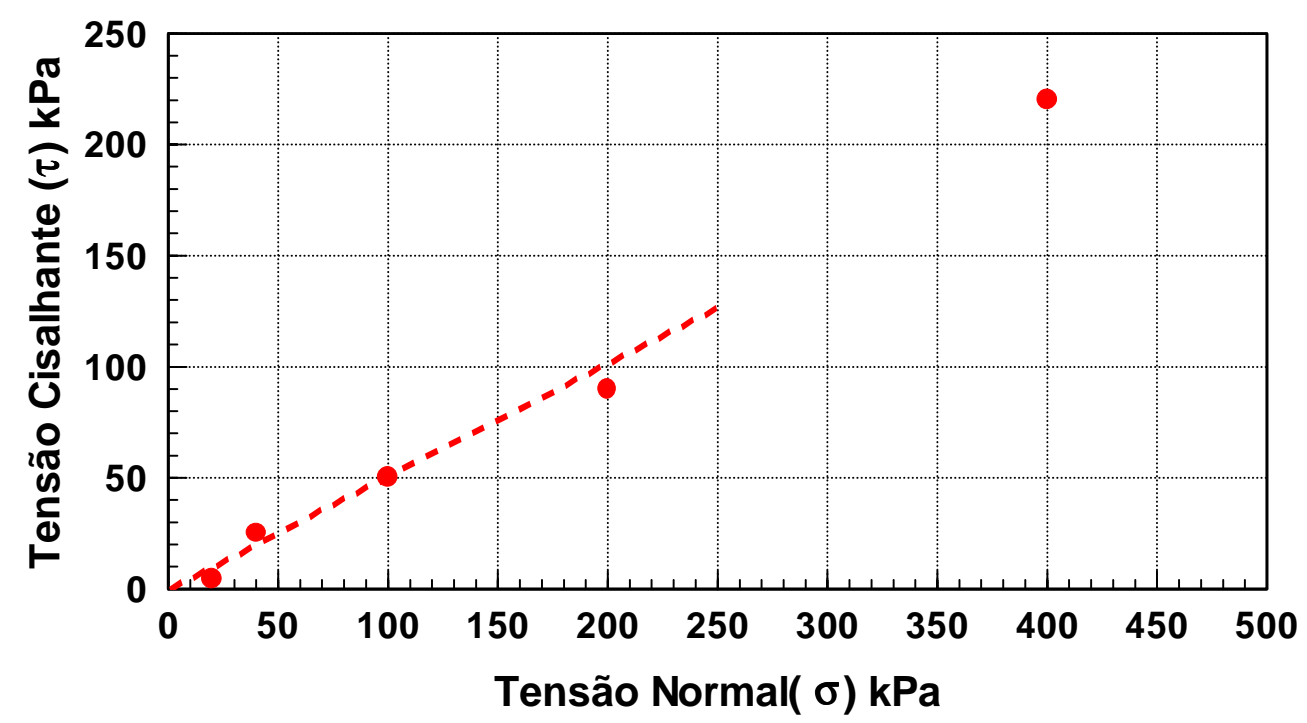

Figura 47 - Envoltória de resistência obtida no ensaio de cisalhamento direto do resíduo da Rigesa.

A Figura 48 ilustra os aspectos das amostras ensaiadas.

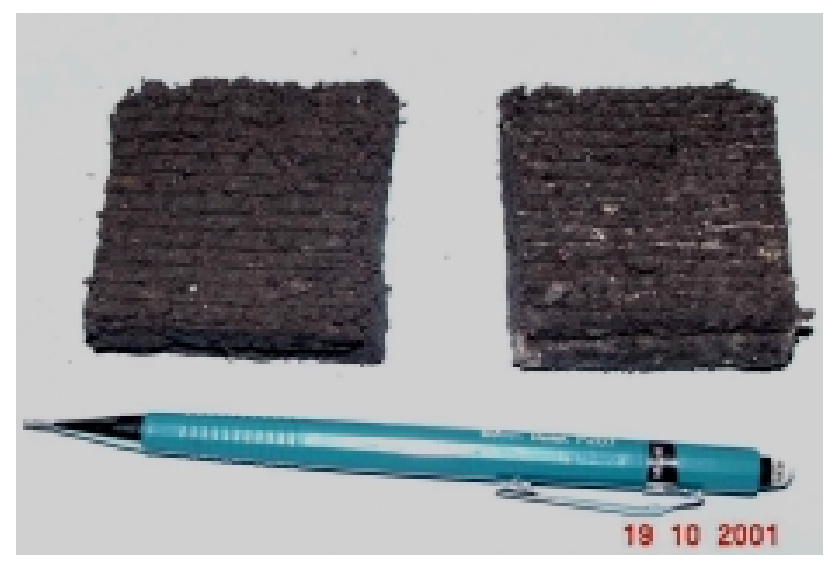

Figura 48 - Amostra da Rigesa após o ensaio de cisalhamento direto. 


\subsection{Determinação da Curva de Retenção}

Foram utilizados dois métodos para impor sucções e assim obter a curva de retenção de água para o resíduo da Rigesa. Um deles foi a placa de sucção e o outro a placa de pressão.

A placa de sucção é mais adequada para as sucções baixas, inferiores a 90 kPa. No Laboratório de Mecânica dos Solos da USP este equipamento foi desenvolvido para aplicar sucção de até $30 \mathrm{kPa}$.

A curva de retenção de água é definida como a relação entre a sucção e a quantidade de água na amostra, podendo este volume ser expresso como teor de umidade gravimétrico, volumétrico ou grau de saturação. Porém, deve-se salientar que esta não é necessariamente uma característica do solo, pois depende também da trajetória de tensões e distribuição de poros (e.g. Marinho \& Chandler, 1993). A capacidade de retenção água pelo material poroso não pode ser analisada apenas com a relação teor de umidade e sucção, deve-se obter as relações entre sucção e grau de saturação e índices de vazios.

Este método impõe a sucção matricial que é dada pela diferença entre a pressão atmosférica (ou pressão do ar) e a pressão na água $\left(u_{a}-u_{w}\right)$. $O$ método da placa de sucção é baseado na diferença de pressão entre dois pontos.

O método tem como princípio a teoria dos vasos comunicantes onde nas duas extremidades do sistema atua a pressão atmosférica. O sistema é interligado entre si através de uma mangueira flexível de pequeno diâmetro onde em uma extremidade está conectado um reservatório de água, e a outra na pedra porosa. 
O sistema compõe-se de uma pedra porosa saturada de 1 bar (100 kPa). Como o sistema mede sucção matricial $\left(u_{a}-u_{w}\right)$ onde $u_{a}$ é a pressão atmosférica e vale zero nas medidas relativas; e $u_{w}$ é a pressão na água e é gerada pela diferença de altura da coluna d'água no sistema. Esta pressão na água é negativa em relação a pressão atmosférica. Na Figura 49 mostra o esquema do sistema. A sucção imposta é a diferença de altura da metade do corpo de prova até o reservatório.

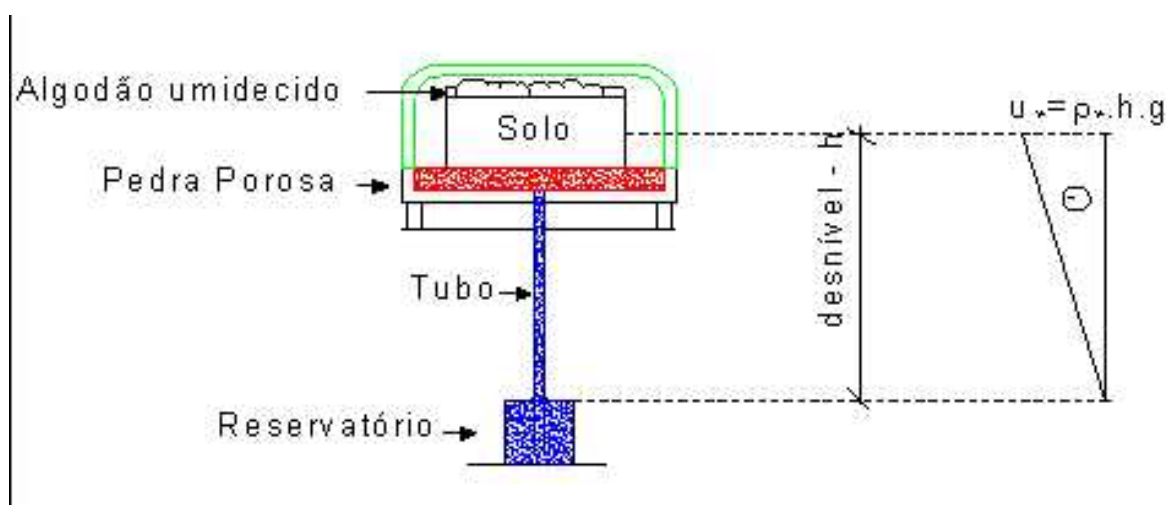

Figura 49 - Esquema do sistema da placa de sucção.

Para a realização do ensaio foram moldados corpos de provas, com diâmetro, altura, peso e umidade inicial conhecidos. Os corpos de prova foram colocados sobre a placa porosa. Os corpos de prova foram saturados adicionando-se água diretamente sobre os mesmos. O sistema é fechado e isolado com filme plástico (PVC) para evitar a perda do teor de umidade do corpo de prova e também da pedra porosa. Acima do corpo de prova é colocado um pequeno recipiente com algodão umedecido com água para manter a umidade relativa elevada. Cada incremento de sucção exigiu um tempo de equilíbrio. O equilíbrio de cada estágio durou cerca de uma semana.

A Figura 50 ilustra o sistema da placa de sucção utilizada, em que se pode observar a plataforma com a placa de sucção e o reservatório de água. A imposição do desnível é feita tanto movimentando-se a plataforma como ajustando-se o reservatório. 

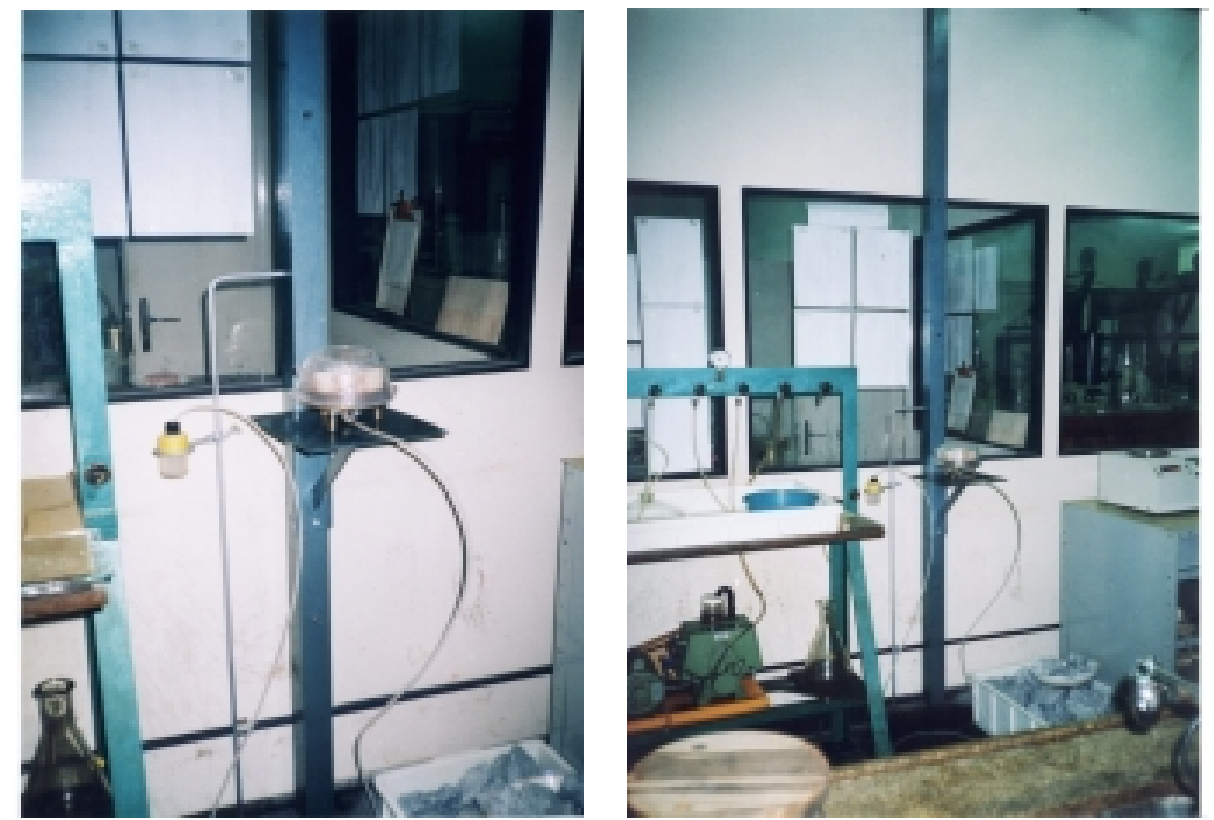

Figura 50 - Esquema do Ensaio de Placa de Sucção do Laboratório de Solos da USP-SP.

Foram ensaiados 6 corpos de prova com a amostra da Rigesa, cujas características estão apresentadas na Tabela 19. Nos três primeiros ensaios não foi possível a construção total da curva de retenção, pois durante a execução do ensaio houve o aparecimento de microorganismos e fungos na amostra. Assim nestes três corpos de prova a sucção máxima aplicada foi de $25 \mathrm{kPa}$. A amostra 3 foi desprezada, pois houve o aparecimento de fungos antes mesmo do inicio da aplicação da pressão para a realização do ensaio.

Na Figura 51 estão apresentados os resultados obtidos para as amostras $1 \mathrm{e}$ 2. A Figura 51 apresenta os resultados em termos de teor de umidade gravimétrico, grau de saturação e teor de umidade volumétrico, todos em função da sucção. Salienta-se que o volume das amostras foi obtido medindo-se externamente o seu volume a cada incremento de sucção. 
4. Metodologia de Ensaio

\begin{tabular}{|c|c|c|c|c|}
\hline Amostra & $\begin{array}{c}\text { Teor de } \\
\text { Umidade }(\%)\end{array}$ & $\begin{array}{c}\text { Densidade } \\
\text { Seca }\left(\mathrm{kN} / \mathrm{m}^{3}\right)\end{array}$ & $\begin{array}{c}\text { Índice de } \\
\text { Vazios }\end{array}$ & $\begin{array}{c}\text { Processo de } \\
\text { Moldagem }\end{array}$ \\
\hline 1 & 188,65 & 3,610 & 3,50 & Proctor \\
\hline 2 & 122,55 & 4,400 & 2,69 & Estático \\
\hline 3 & 40.32 & 5,970 & 1,72 & Estático \\
\hline 4 & 393,85 & 2,260 & 6,319 & Modelo reduzido \\
\hline 5 & 399,57 & 2,223 & 6,319 & Modelo reduzido \\
\hline 6 & 255,70 & 2,942 & 4,523 & Modelo reduzido \\
\hline
\end{tabular}

Tabela 19 - Características do Resíduo da Rigesa no ensaio de Placa de Sucção.
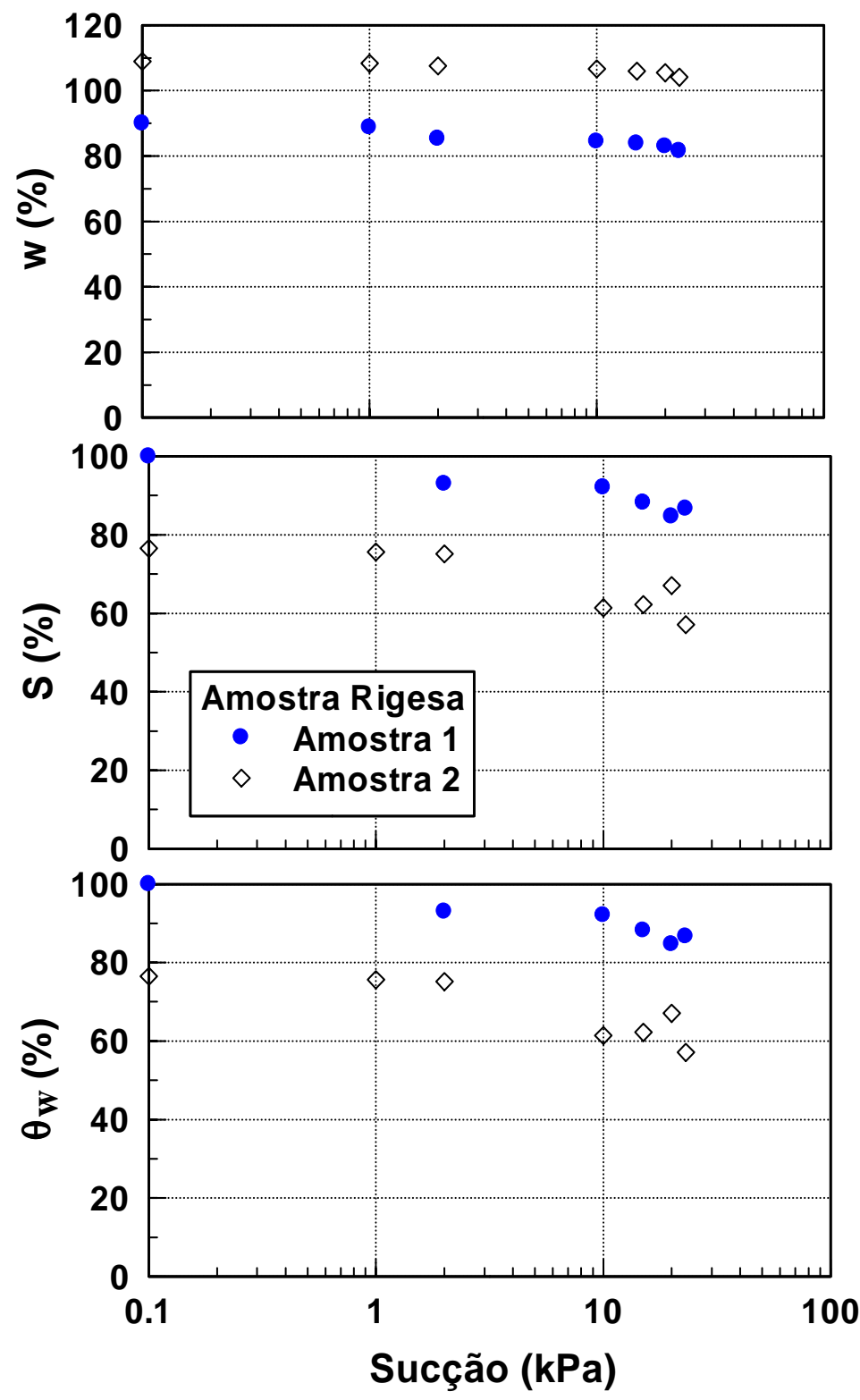

Figura 51 - Curva de retenção do resíduo da Rigesa. 
Outros três corpos de prova foram moldados, utilizando-se o procedimento de compactação descrito no item 4.5.2.

Na Figura 52 estão apresentados os resultados obtidos para as amostras 4, 5 e 6. Eles são apresentados em termos de teor de umidade gravimétrico, grau de saturação e teor de umidade volumétrico, todos em função da suç̧ão.

Para evitar o aparecimento de fungos na amostra durante o ensaio de placa de sucção foi adicionado às amostras um fungicida. Esta adição foi feita borrifando-se o fungicida diretamente no corpo de prova depois de compactado. Após este processo, a amostra foi levada para a placa de sucção onde se deu ínicio ao ensaio.

Para níveis de sucção superiores a $30 \mathrm{kPa}$ utilizou-se a técnica da placa de pressão. A placa de pressão funciona se utilizar a técnica da translação de eixos (e.g. Fredlund e Rahardjo, 1993).

Na placa de pressão, as sucção aplicadas foram 50, 100, 200, 300, $400 \mathrm{kPa}$. Os corpos de prova utilizados foram os mesmos ensaiados na placa de sucção, ou seja, amostras 4,5 e 6 . As características destes corpos de prova estão apresentadas na Tabela 19. Salienta-se que os valores iniciais apresentados para as amostras 4, 5 e 6 referem-se à situação após a aplicação do fugicida.

A estabilização da amostra era controlada pelo peso da amostra, quando o peso mantinha-se constante media-se a altura e o diâmetro da amostra, e aumentava-se a sucção. 

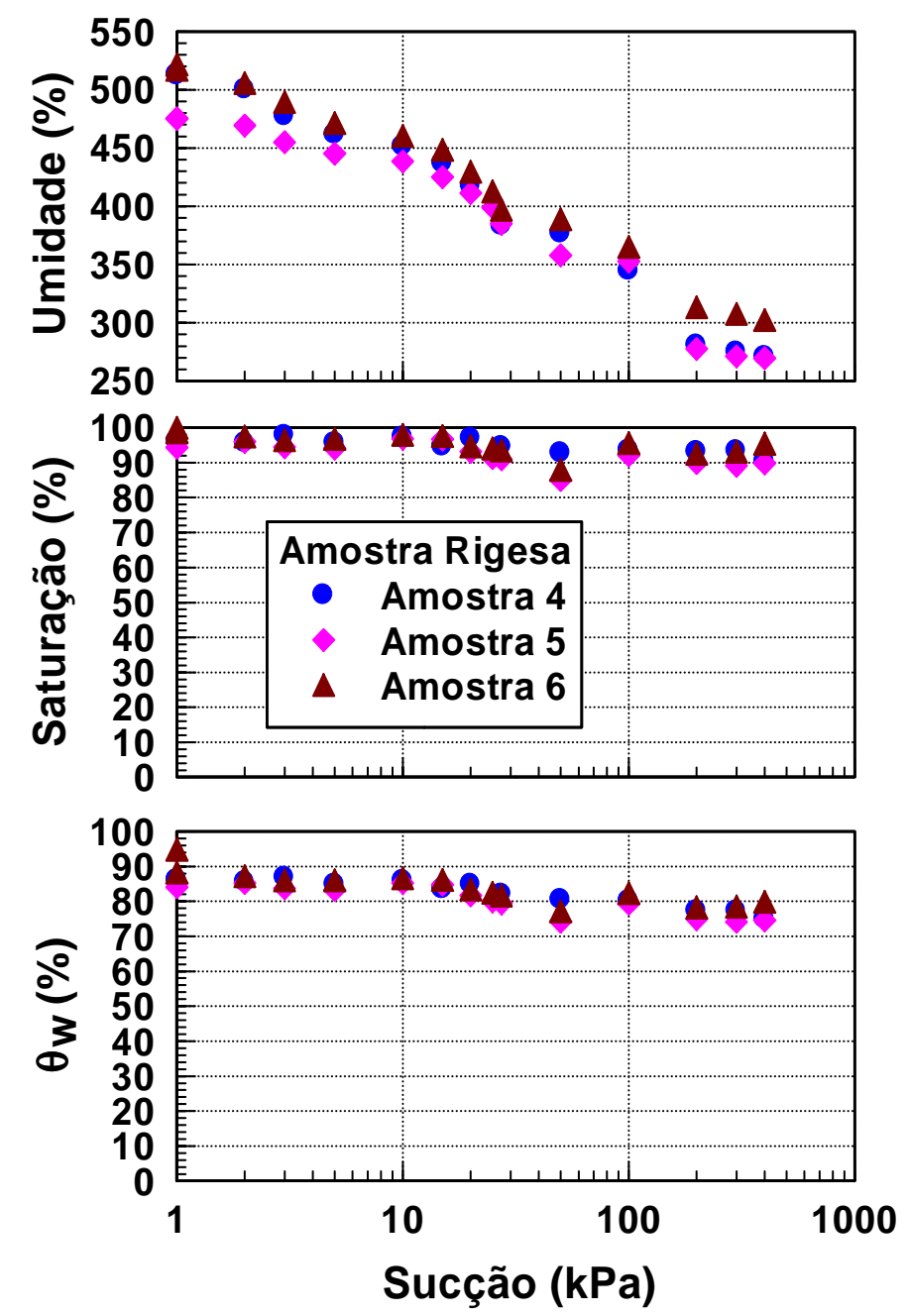

Figura 52 - Curva de retenção das amostras da Rigesa.

Observando-se os resultados, tanto da primeira série como da segunda, pode-se concluir que não se chegou ao valor de entrada de ar das amostras. Salienta-se que o índice de vazios das amostras 1 e 2 foi significativamente menor do que o das amostras 4, 5 e 6. A manutenção da saturação nas amostras está associado, possivelmente a uma variação de volume correspondente ao volume de água removido. 


\section{Comparação entre os resíduos da literatura e o resíduo da Rigesa.}

Com o objetivo de comparar as características geotécnicas do resíduo de papel da Rigesa com os resíduos apresentados pela literatura, foi feita uma compilação das informações disponíveis. Estas informações estão apresentadas em forma de gráfico e tabelas que facilitam a visualização e análise das eventuais diferenças e semelhanças.

Analisando-se 0 aspecto relacionado com a natureza do material apresenta-se na Figura 53 a relação entre a densidade dos "grãos" e o teor de matéria orgânica. Observa-se que o resíduo da Rigesa (RIG) é o que apresenta o maior teor de matéria orgânica e em conseqüência uma menor densidade dos "grãos".

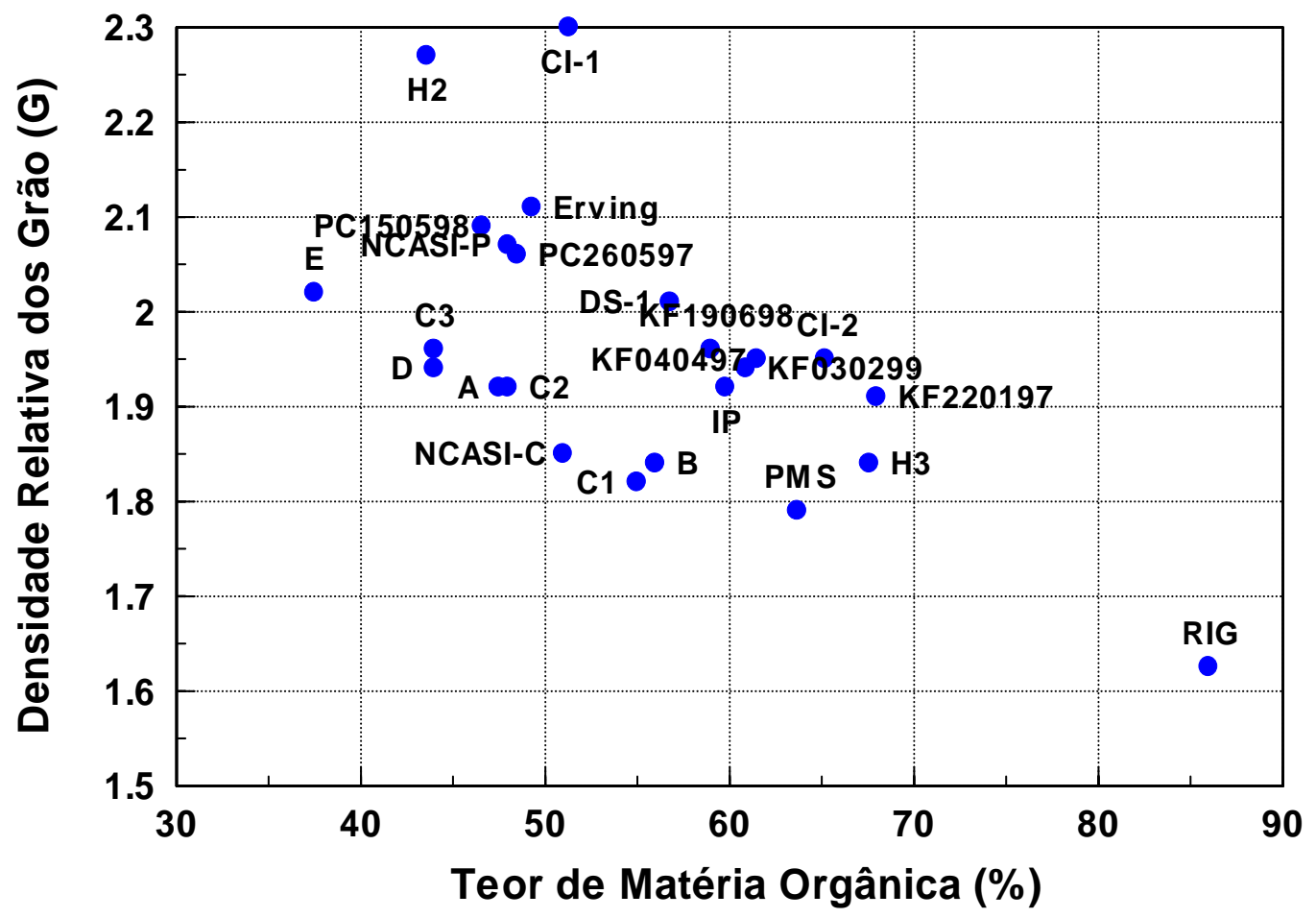

Figura 53 - Relação entre a densidade relativa dos grãos e o teor de matéria orgânica. 
Com relação aos limites de Atterberg observa-se na Figura 54 que o resíduo da Rigesa apresenta-se com o maior limite de liquidez e maior índice de plasticidade em comparação com os da literatura. Observa-se ainda que todos se encontram abaixo da linha. Para a execução dos ensaios de limite de plasticidade o resíduo da Rigesa apresentou as mesmas dificuldades encontradas nos resíduos estudados por Moo-Young e Zimmie, (1996) e LaPlante, (1993). As fibras contidas no resíduo dificultam a abertura da ranhura no ensaio de limite de liquidez pelo método de Casagrande. Os limites de liquidez executados pelo método de Casagrande e através do método do Cone apresentaram uma boa concordância. No entanto, aconselha-se a execução do ensaio de limite de liquidez por meio do Cone pela facilidade do mesmo, pois pelo método de Casagrande existe a dificuldade de abrir-se a ranhura na amostra com o cinzel padronizado.

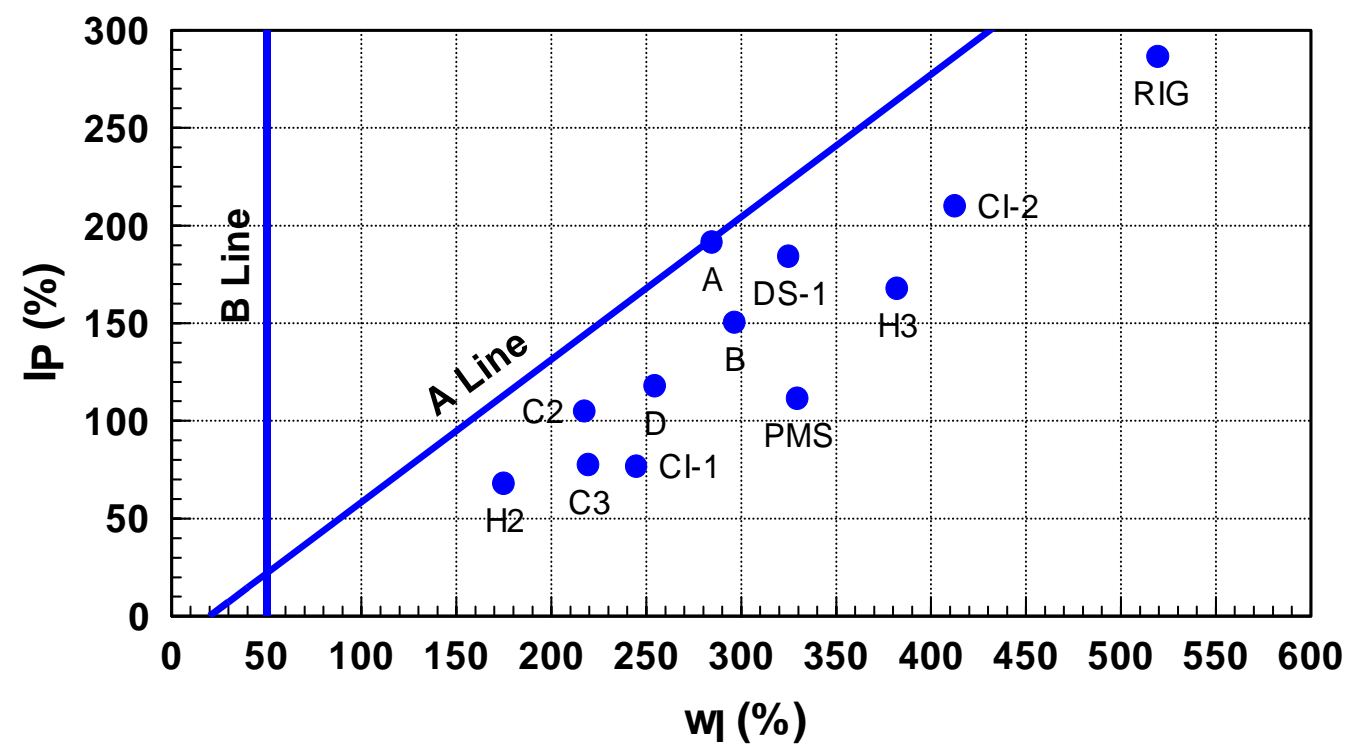

Figura 54 - Carta de plasticidade.

Na Figura 55 apresenta-se a relação entre a máxima densidade seca $\left(\gamma_{d}\right)$ e 0 teor de umidade ótimo $\left(\mathrm{w}_{\mathrm{ot}}\right)$ para os resíduos apresentados na Tabela 1. 


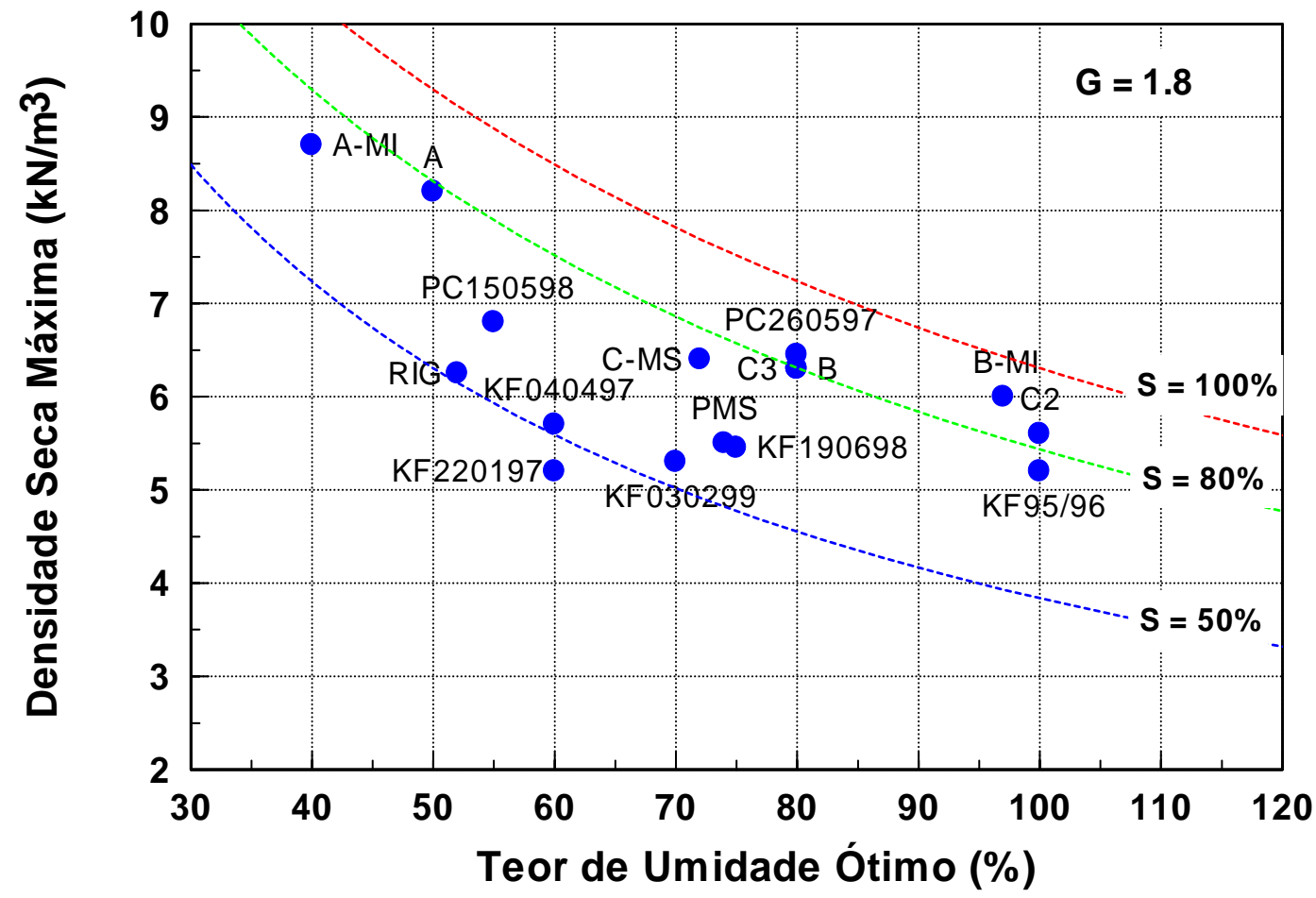

Figura 55 - Relação entre o teor de umidade ótimo e a densidade seca máxima.

Observa-se na Figura 55 que, para a maioria dos resíduos, a umidade ótima varia aproximadamente entre $50 \%$ e 100\%. A densidade seca máxima varia aproximadamente de 5,0 a $8,0 \mathrm{kN} / \mathrm{m}^{3}$ e o grau de saturação para a umidade ótima varia de $45 \%$ a 90 \%. Ensaios realizados com a energia do Proctor modificado no resíduo da Rigesa não apresentou qualquer variação nos valores obtidos no que se refere a densidade seca máxima e teor de umidade ótimo.

A relação entre o teor de matéria orgânica e o grau de saturação no teor de umidade ótimo é apresentada na Figura 56. Pode-se observar que as duas são inversamente proporcionais: Um aumento no teor de matéria orgânica é associado com a redução no grau de saturação na ótima. Esta informação sugere que a presença de matéria orgânica dificulta a compactação do material. 


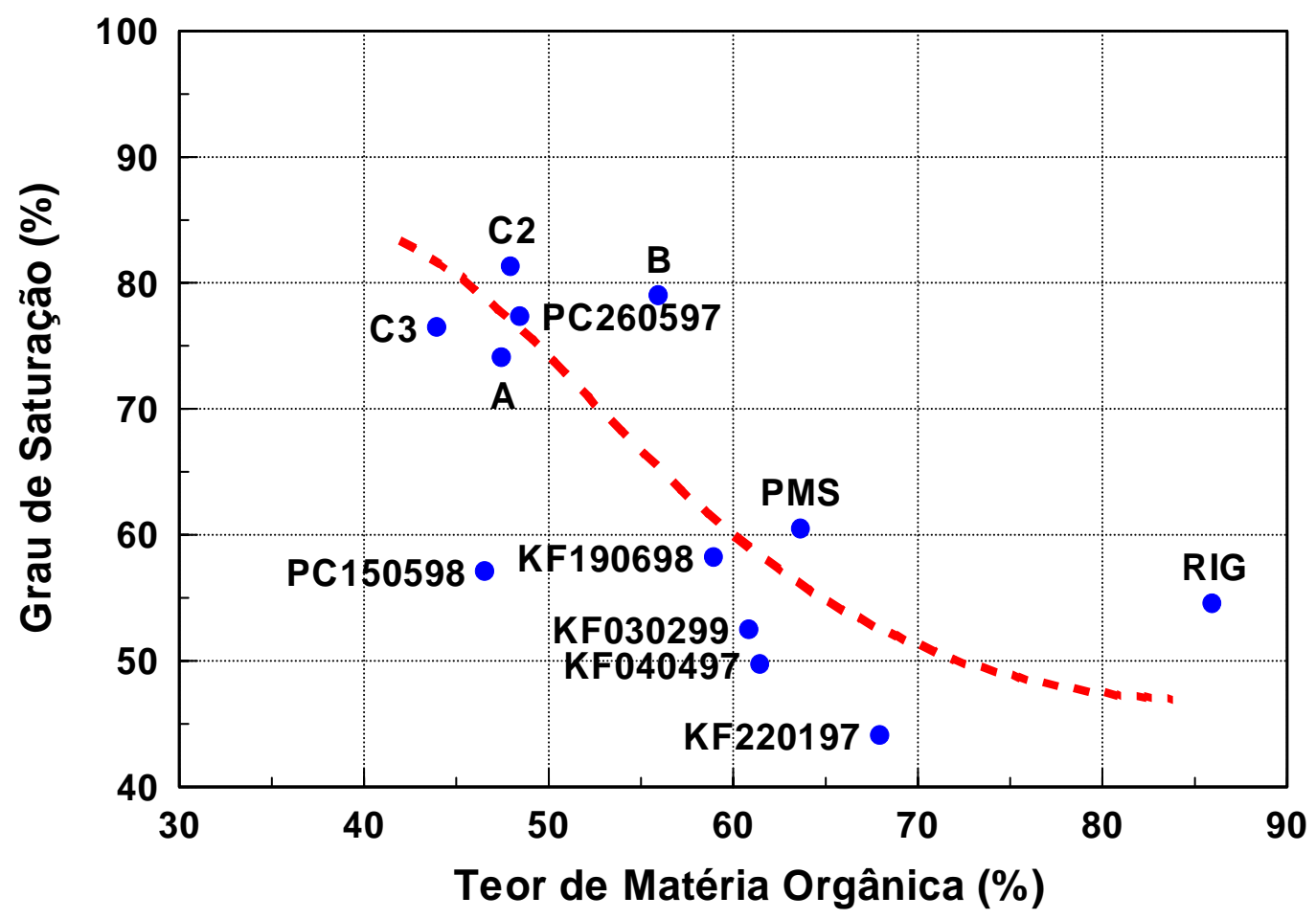

Figura 56 - Relação entre o grau de saturação na ótima e o teor de matéria orgânica.

$\mathrm{Na}$ Tabela 20 apresentam-se os valores do intercepto de coesão e ângulo de atrito para o resíduo da Rigesa e os resíduos estudados por Moo-Young e Zimmie (1996). Observa-se que o resíduo da Rigesa apresenta maior coesão e menor ângulo de atrito. Na Figura 57 ilustra-se a relação entre a envoltórias do resíduo da Rigesa com as da literatura.

\begin{tabular}{|c|c|c|}
\hline Resíduo & Ângulo de atrito $(\phi)$ & Coesão $(c)$ \\
\hline A (teste1) & 37 & 2,8 \\
\hline A (teste2) & 25 & 9,0 \\
\hline B & 37 & 5,5 \\
\hline E & 32 & 9,0 \\
\hline F & 40 & 5,5 \\
\hline Rigesa & 22 & 10 \\
\hline
\end{tabular}

Tabela 20 - Comparação entres resíduos estudados por Moo-Young e Zimmie (1996) e Rigesa. 


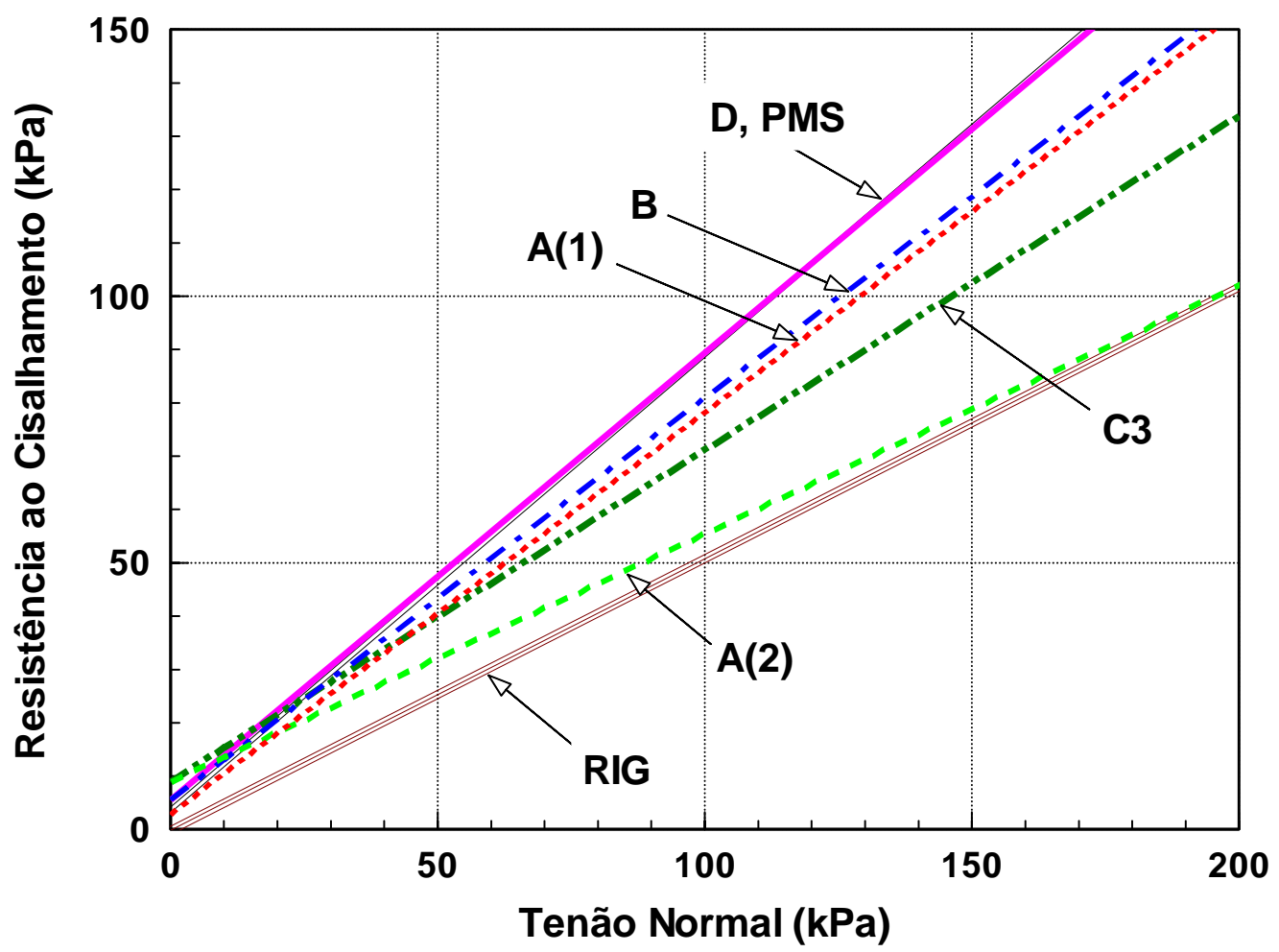

Figura 57 -Envoltória de Resistência de alguns resíduos.

Como uma das conseqüências da variação da resistência é atribuída ao teor de matéria orgânica (e.g. Moo-Young e Zimmie ,1996), esperava-se encontrar um valor de coesão superior aos literatura para o resíduo da Rigesa e um ângulo de atrito menor.

Os dados dos ensaios de adensamento obtidos para o resíduo da Rigesa apresentaram uma variação no índice de compressão $\left(\mathrm{C}_{c}\right)$ de 0,79 a 1,88 . Esta variação de valores esta associada à variação do teor de umidade da amostra que variou entre 51,14 a 131,07. O índice de compressão aumenta com o teor de umidade inicial da amostra.

$\mathrm{Na}$ literatura, como visto no item 3.14 encontram-se algumas correlações empíricas para a obtenção do índice de compressão. Aplicando as expressões 2 e 3 e 6 para o resíduo da Rigesa podemos comparar os índices de compressão encontrados no laboratório com as correlações apresentas por 
Wang et.al (1991) e Moo-Young e Zimmie (1996) . Na Tabela 21 estão apresentados os valores calculados juntamente com os valores obtidos experimentalmente para o resíduo da Rigesa.

\begin{tabular}{|c|c|c|c|c|c|c|}
\hline Amostra & $\mathrm{W}_{0}(\%)$ & $\mathrm{e}_{\circ}$ & $\mathrm{Cc}$ (ensaio) & $\begin{array}{c}\mathrm{Cc}=0,009 \mathrm{w}_{0} \\
\text { Eq. } 2\end{array}$ & $\begin{array}{c}\mathrm{Cc}=0,39 \mathrm{e}_{0} \\
\text { Eq. 3 }\end{array}$ & $\begin{array}{c}\mathrm{Cc}=0,027 \mathrm{O}_{\mathrm{c}} \\
\text { Eq. 9 }\end{array}$ \\
\hline 1 & 51,14 & 2,710 & 0,79 & 0,46 & 1,05 & 2,3 \\
\hline 2 & 125,94 & 2,727 & 1,36 & 1,13 & 1,06 & 2,3 \\
\hline 3 & 130,20 & 2,824 & 1,2 & 1,17 & 1,10 & 2,3 \\
\hline 4 & 131,07 & 3,822 & 1,45 & 1,18 & 1,49 & 2,3 \\
\hline 5 & 131,07 & 3,880 & 1,87 & 1,18 & 1,51 & 2,3 \\
\hline 6 & 131,07 & 3,440 & 1,88 & 1,18 & 1,34 & 2,3 \\
\hline
\end{tabular}

Tabela 21 - Comparação do índice de compressão encontrado no laboratório com correlações apresentadas por Wang et al. (1991) e Moo-Young e Zimmie (1996).

Nota-se uma boa aproximação das correlações (2 e 3) apresentadas por Wang et al. (1991) com os resultados dos ensaios da Rigesa. Moo-Young e Zimmie (1996) apresentaram uma correlação do Cc com o teor de matéria orgânica, observa-se na Tabela 21, no entanto, que esta relação não é muita boa para o resíduo da Rigesa, apresentando um Cc muito elevado em comparação com Cc experimental. Salienta-se que uma correlação unicamente com o teor de matéria orgânica não poderia ser adequada, pois o teor de umidade inicial tem um papel fundamental no comportamento do material.

Na Figura 58 apresentam-se os valores de Cc obtidos da literatura juntamente com a correlação sugerida por Wang et al (1991) e apresentada por MooYoung (1996). Pode-se observar uma boa concordância para os valores obtidos e avaliados. Os dados para o resíduo de papel da Rigesa também são apresentados na Figura 60. A correlação apesar de não ser desenvolvida para materiais compactados, apresentou uma boa concordância para o resíduo da Rigesa. 


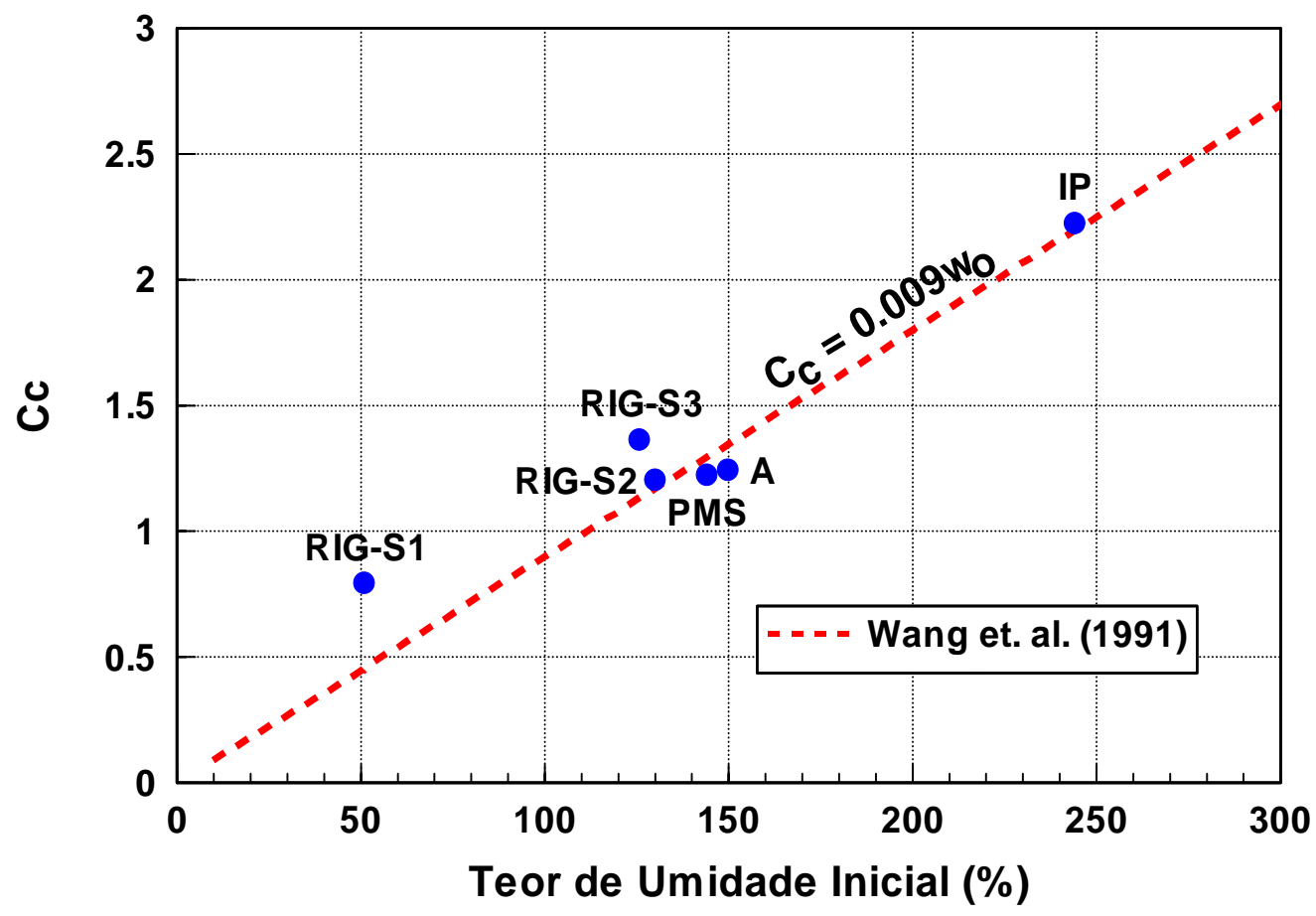

Figura 58 - Correlação entre Cc e teor de umidade inicial.

$\mathrm{Na}$ Figura 59 estão apresentados os valores do intercepto de coesão e o ângulo de atrito de vários resíduos em função do teor de matéria orgânica. Observa-se que não há uma correlação direta com o teor de matéria orgânica. 
5.Comparação entre os resíduos da literatura e o resíduo da Rigesa.

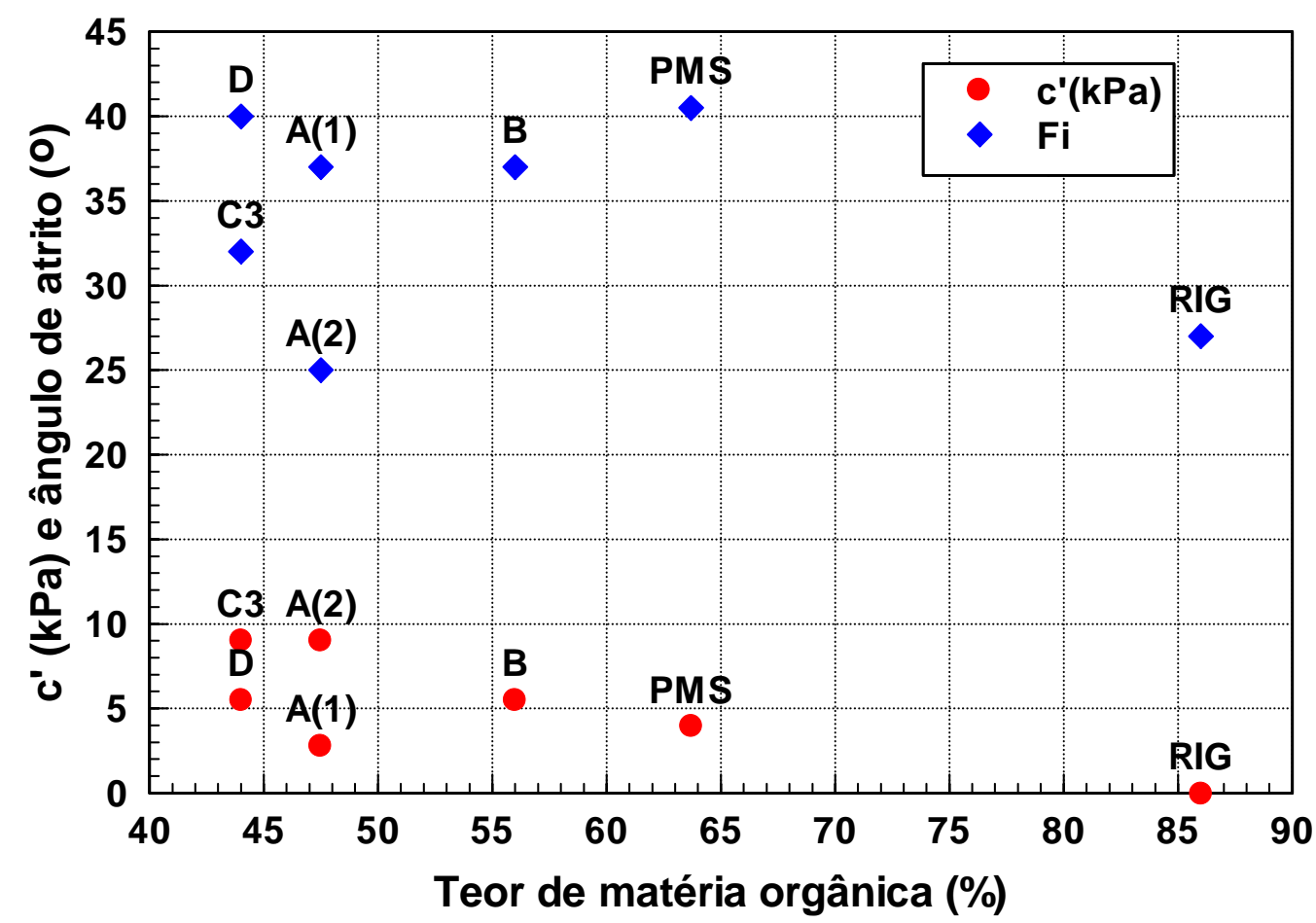

Figura 59 - Relação entre o intercepto de coesão e o ângulo de atrito com o teor de matéria orgânica.

Com relação aos valores dos coeficientes de permeabilidade obtidos com 0 resíduo da Rigesa comparados com os encontrados na literatura podemos destacar que não se observou uma redução significativa no valor do coeficiente de permeabilidade com a redução do índice de vazios. Na Figura 60 apresentam-se os resultados obtidos para o coeficiente de permeabilidade em função do índice de vazios, durante o ensaio de adensamento.

Os resultados obtidos por Cabral et al. (1997) indicam uma variação para o coeficiente de permeabilidade de $10^{-5} \mathrm{~cm} / \mathrm{s}$ a $10^{-8} \mathrm{~cm} / \mathrm{s}$, para uma variação no índice de vazios de aproximadamente 3,3 a 1,4. Salienta-se que os valores encontrados por Cabral et al. (1997) para amostras compactadas com teor de umidade próximo da ótima são da mesma ordem de grandeza dos obtidos para o resíduo da Rigesa. 
5.Comparação entre os resíduos da literatura e o resíduo da Rigesa.

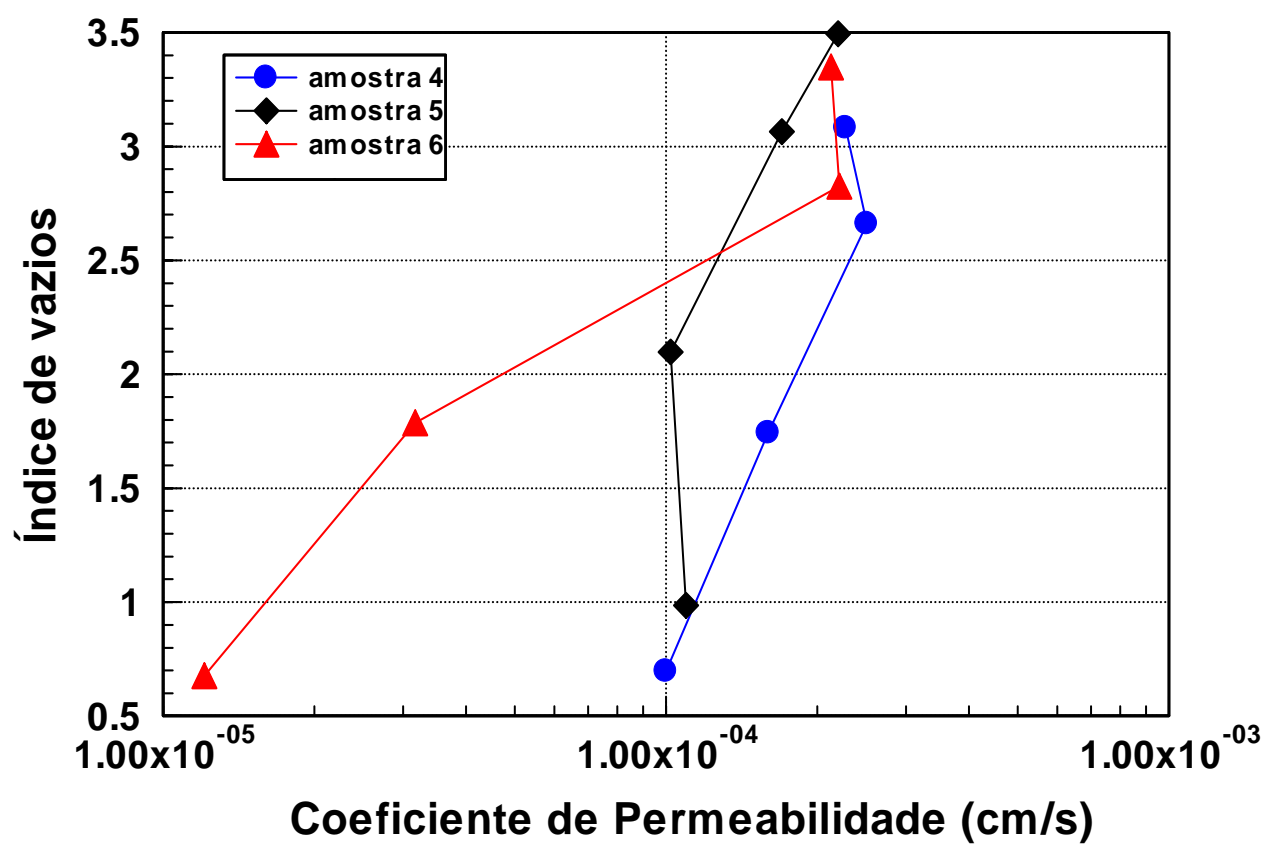

Figura 60 - Relação entre o índice de vazios e o coeficiente de permeabilidade.

Uma possível explicação para a baixa redução da permeabilidade com o índice de vazios é a seguinte: caso a saturação da amostra não tenha sido atingida a permeabilidade em cada estágio pode estar sendo influenciada tanto pela redução do índice de vazios como pela eventual expulsão do ar da amostra. Como estes efeitos têm conseqüências opostas 0 coeficiente de permeabilidade se manteria constante. No entanto, isto não explicaria o alto valor do coeficiente de permeabilidade do resíduo da Rigesa, quando comparado com os encontrados na literatura para baixos índices de vazios.

Salienta-se ainda que os processos biológicos durante o ensaio podem causar fenômenos que não puderam ser avaliados adequadamente. Estes fenômenos biológicos podem causar geração de gases que dificultam a interpretação dos resultados obtidos.

A determinação das características de retenção de água em resíduos de papel não é comum de serem encontradas na literatura. O valor da sucção de entrada de ar obtido para o resíduo da Rigesa é superior aos encontrados por Cabral et al. (2002). Cabral et al. (2002) encontram valores variando entre 15 e 
5.Comparação entre os resíduos da literatura e o resíduo da Rigesa.

$25 \mathrm{kPa}$, enquanto o valor obtido para o resíduo da Rigesa foi superior a $50 \mathrm{kPa}$. Observa-se na Figura 52 que o grau de saturação da amostra se apresentou elevado para o maior nível de sucção imposto 


\section{Conclusões}

Com base nas informações encontradas na literatura e fazendo uso da experiência obtida com a realização dos ensaios geotécnicos no resíduo de papel da Rigesa, podemos apresentar as seguintes conclusões:

- Por ser um material excessivamente fibroso e orgânico, o ensaio de determinação da distribuição granulométrica não se mostrou aplicável.

- Os resultados obtidos com a determinação dos limites de Atterberg apresentaram resultados que refletem, de forma razoável, o comportamento potencial do material.

- Embora a determinação do limite de liquidez pelo método de Casagrande e pelo método do cone fornecem valores muito semelhantes, sugere-se que seja utilizado o cone, pois o mesmo é menos susceptível às diferenças devidas ao operador.

- O resíduo da Rigesa posiciona-se, na carta de plasticidade, abaixo da linha $A$ e muito a direita da linha B. Embora não seja adequado se classificar o resíduo com a nomenclatura geotécnica, observamos que o material pode ter seu comportamento potencial inferido com base no seu posicionamento na carta de plasticidade.

- A determinação da curva de compactação confirmou que o material não apresenta pico bem caracterizado. Observou-se ainda que o aumento da energia de compactação não afetava a curva de compactação obtida.

- O uso do mini-Proctor mostrou-se mais eficiente para a obtenção de amostras mais homogêneas.

- A análise dos ensaios de adensamento confirmou a elevada compressibilidade do material, mesmo no estado compactado.

- Não foi possível distinguir entre o adensamento primário e o secundário.

- O critério mais adequado para mudança de estágio no adensamento foi por meio do monitoramento da velocidade de deslocamento. 
- A resistência ao cisalhamento do material indicou um valor de ângulo de atrito no limite inferior aos dos encontrados na literatura. Já o intercepto de coesão mostrou-se inferior aos da literatura e igual a zero.

- Os ensaios de permeabilidade realizados durante o ensaio de adensamento, não conduziram a resultados de fácil interpretação. Aspectos relacionados com os processos biológicos podem ter afetado o comportamento do fluxo da água no material.

- A obtenção das características de retenção de água do material foi dificultada pela ação biológica do material. Ou seja, a formação de fungos e o aparecimento de micro-organismos dificultaram o estudo do material no seu estado não saturado. Para minimizar este problema foi necessário o uso de um bactericida.

- As curvas de retenção obtidas para o material sugerem um valor de entrada de ar, para a amostra compactada, superior a $50 \mathrm{kPa}$. Esta informação permite se concluir que o material é adequado para ser utilizado como um dos elementos de barreiras capilares, onde a manutenção da saturação é fundamental.

- As correlações empíricas encontradas na literatura para a estimativa de parâmetros geotécnicos, na maioria das vezes não podem ser generalizadas para todos os tipos de resíduos.

- A aplicação do resíduo de papel em coberturas de proteção ambiental é plenamente factível. Deve-se, no entanto, considerar detalhadamente a sua elevada compressibilidade, baixa resistência e seu potencial de degradação.

- O uso de resíduos da indústria para fins geotécnicos deve levar em conta a eventual variabilidade destes resíduos na sua fonte. Deve haver uma total conscientização por parte da indústria sobre a qualidade do resíduo gerado.

- Como fruto dos estudos realizados, conclui-se que é necessário se aprofundar os estudos relativos a:

- Permeabilidade do material associado, não só a sua variação de índice de vazios, mas também com relação ao efeito biológico que ocorre com o tempo. 
- Os processos de deformação devem ser mais detalhadamente estudados para se melhorar os métodos de previsão de recalque para os resíduos de papel.

- As características da fibra do resíduo de papel principalmente seu comprimento e diâmetro e a influência das mesmas nos ensaios. 


\section{Referências}

AL-Khafaji, A. W. N. e Andersland, O. B. (1981a), "Ignition test for soil organiccontent measurement." Journal of the Geotchnical Engineering Division,v.4, p.465-479, Apr. 1981.

AL-Khafaji, A. W. N. e Andersland, O. B. (1981b) "Compressibility and strength of decomposing fibre-clay soils." Geotechique, v. 4, p.497-508, Apr. 1981.

Andersland, O. B.. e Mathew, P. J., (1973) "Consolidation of high Ash paper mill sludges", Journal of the Soil Mechancs and Foudations Division, v. 99 p.365-374 May. 1973

Andersland, O. B.,(1998) "Geotechinical properties of paper mill sludges for use in landfill covers". discussion, Journal of Geoenvironmental Engineering, v. 4, p. 370-371, Apr.

Benoît, J., Eighmy, T.T. e Crannell, B. S., (1999) " Landifill ASH / sludge mixtures" Journal of Geotechnical and Geoenvironmental Engineering, v. 125 №10, p 877-888.

Berry, P.L. e Vickers, B., (1975) "Consolidation of fibrous peat", Journal of Geotechnical Engineering Division. p 741-753, aug.

Cabral, A.R., Lefebvre, G. Burnotte, F. Panarotto, C.T. e Pastore, E.L., (1999) "Use of pulp and paper residues as an alternative cover material to landifill and to acid generating tailings." . Segundo Seminário de Meio Ambiente em Industria de Processo. São Paulo,Jun p. 56-70

Cabral, A. R., Burnotte, F. e Lefebvre, G (1999) "Design construction and monitoring of waster rock cover using pulp and paper residues". 


\section{Symposiun on Tailings and Mine Wastes, Fort Collins, Colorado.,} Jan., p 405-415 Proceedings

Cabral, A. R., Burnotte, F. e Lefebvre, G.(2002). "Geotechnical characterization of a pulp and paper (deinking) residue used in cover systems." Environmental Geotechincs (4 ICEG), v. 1, p. $207-212$.

Day, R.W.(1998) "Geotechnical properties of paper mill sludges for use in landfill covers". Discussion, Journal of Geoenvironmental Engineering, v. 4, p. 370-371, Apr.

Kamon, M., Katsumi, T., Rajaseakran, G. e Inazumi, S. (2000) "Waste sludges utilization as landfill cover", Geo-Eng 2000, Melbourne, Australia, CDROM.

Kraus, J. F., Benson, C. H. Van Maltby, C. e Wang, X. (1997) "Laboratory and field hydraluic conductivity of three compacted paper mill sludges", Journal of Geotechnical and Geoenvironmental Engineering , v. 123 ํo7 , p. 654-662, july.

Lamber, T. W. (1951) ,"Soil testing for engineers" The Massachussatts of Techncology.

Marinho, F.M. e Chandler, R.J. (1993) - Discussão - "The behavior at the shrinkage limit of clay undergoing drying" -ASTM- Geotechnical Testing Journal $-v 16$ no $4-$ p. 563.

Moo-Young, H.K. e Zimmie, T. F., (1996) "Geotechnical properties of paper mill sludges for use in landfill cover" Journal of Geotechnical Engineering, .p.768-775, Sept. 
Moo-Young, H.K. e Zimmie, T. F.,(1996) "Effects of organic decomposition mill sludges as landfill cover material”, Environmental Geotechnics, p.827832 - Masashi Kamon (editor) (Balkema).

Associação Brasileira de Normas Técnicas. (ABNT). Determinação do teor de umidade NBR 5457/1986

- Determinação do teor de Orgânico NBR 13600

- $\quad$ Solo - Análise Granulometrica MB -32, NBR 7181

- Grão de solos que passam na peneira de 4,8 mm - Determinação de Massa específica MB - 28, NBR 6508

- $\quad$ Solo - Determinação do limite de liquidez MB - 30 NBR 6459

- Solo - Determinação do limite de liquidez método do cone BS 1377, parte 2: 1990

- $\quad$ Solo - determinação do limite de plasticidade MB - 31 NBR 180

- $\quad$ Solo - Ensaio de Compactação MB - 33 NBR 7182

- Solo Ensaio de adensamento unidimensional

Pinto, C. S. (2000) "Curso básico de mecânica dos solos." São Paulo Editora Oficina de Textos.

Pinto,C.S.(1965) "Equipamento reduzido para moldagem de corpo de prova de solo- aditivo", I Simpósio sobre Pesquisas Rodoviárias, Rio de Janeiro. ago.

Quiroz, J. D. e Zimmie T. F., (1998) "Paper mill sludger landfill cover construction." recycled materils in geotechnical applications, Geotechnical Special publication Number v.79, p.19 - 36.

Quiroz, J. D., Simpson P. T., e Zimmie T. F., (2000), "Evaluation of paper sludge landfill cover settlement ", Environmental Geotechnics, Geotechnical Special Publication, v. 105, p.16-31. 
Rodrígues, R. e Badillo J. (1974) "Mecánica de suelos" Tomo I Fundamentos de la Mecánica de Suelos, Ed. Limusa.

Wang, M. C. e Tseng, W. ,(1993) "Permeability behavior of water treatment sludge", Journal of Geotechnical Engineering, V. 119, p.1672 1677.

Zimmies, F. T. e Moo-Young, H. K. (1995), "Hydraulic conductivity of paper sludger used for landfill covers". Specialty Conference on Geoenvironment 2000, Special publication, v.46, p. 932-945. 